\title{
O PRINCÍPIO DO POLUIDOR-PAGADOR NA JURISPRUDÊNCIA DO STF E DO STJ: UMA ANÁLISE CRÍTICA ${ }^{1}$
}

\author{
Danielle de Andrade Moreira \\ Doutora e Mestre em Direito pela Universidade do Estado do Rio de Janeiro (UERJ). Professora \\ adjunta da Pontifícia Universidade Católica do Rio de Janeiro, com atuação junto ao Programa de \\ Pós-Graduação em Direito e ao Núcleo Interdisciplinar de Meio Ambiente (NIMA/PUC-Rio). Coorde- \\ nadora do Grupo de Pesquisa Direito, Ambiente e Justiça no Antropoceno (JUMA) do NIMA/PUC- \\ Rio. Membro do Conselho Consultivo do NIMA/PUC-Rio. Coordenadora Acadêmica do Curso de \\ Pós-graduação lato sensu (nível especialização) em Direito Ambiental da PUC-Rio. \\ E-mail: daniamoreira@puc-rio.br
}

Letícia Maria Rêgo Teixeira Lima

Mestranda em Teoria do Estado e Direito Constitucional pela Pontifícia Universidade Católica do Rio de Janeiro (PUC-Rio). Especialista em Direito Ambiental Brasileiro pela PUC-Rio. Bacharel em Direito pela PUC-Rio. Pesquisadora do Grupo de Pesquisa Direito, Ambiente e Justiça no Antropoceno (JUMA) do NIMA/PUC-Rio. E-mail: leticialima.ambiental@gmail.com

Izabel Freire Moreira

Especialista em Direito Ambiental Brasileiro pela Pontifícia Universidade Católica do Rio de Janeiro (PUC-Rio). Bacharel em Direito pela PUC-Rio. E-mail: izafreire.m@gmail.com

\section{RESUMO}

O reconhecimento da importância e do potencial - muitas vezes subestimado - do princípio do poluidor-pagador tem o condão de fortalecer os diversos instrumentos jurídico-ambientais dedicados a promover a distribuição equitativa dos ônus e bônus socioambientais e a concretização do direito fundamental ao meio ambiente equilibrado. Este texto reflete a respeito de pesquisa, desenvolvida em 2014 e atualizada em 2017 e 2018, sobre a aplicação do princípio do poluidor-pagador pelo Supremo Tribunal Federal (STF) e Superior Tribunal de Justiça (STJ). O principal objetivo foi o de analisar criticamente como o referido princípio - consideradas sua origem histórica, relevância e amplitude - tem incidido na jurisprudência relativa à tutela jurídica do meio ambiente, tendo em vista a busca pela efetividade do direito fundamental ao meio ambiente equilibrado. O estudo compreendeu levantamento bibliográfico e documental, acompanhado de catalogação e análise crítica do material selecionado; a metodologia adotada incluiu levantamento, sistematização e análise qualitativa de acórdãos julgados no período de 1993 a 2018 no âmbito do STF e STJ. Foi possível observar que, no que concerne à sua dimensão reparatória, o princípio do poluidor-pagador tem cumprido importante papel no aperfeiçoamento da responsabilidade

1 A pesquisa foi financiada pelo CNPq (bolsas de iniciação científica). 
civil ambiental, servindo de fio condutor teórico para a solução de vários dos desafios à reparação integral dos danos ambientais. Quanto à dimensão preventiva do referido princípio, igualmente relevante para a melhor aplicação de ferramentas que promovam a justiça distributiva em matéria ambiental, pôde-se verificar sua significativa subutilização.

Palavras-chave: Princípio do poluidor-pagador; externalidade ambiental negativa; internalização de custos ambientais; prevenção e reparação de danos ambientais; responsabilidade civil ambiental.

\section{THE POLLUTER-PAYS PRINCIPLE IN THE BRAZILIAN SUPERIOR COURTS: A CRITICAL ANALYSIS}

\section{ABSTRACT}

The recognition of the importance and potential - often underestimated - of the polluter-pays principle has the power to strengthen the various legal and environmental instruments dedicated to promoting the equitable distribution of socio-environmental burdens and bonuses and the realization of the fundamental right to a balanced environment. This text reflects a research, developed in 2014 and updated in 2017 and 2018, on the application of the polluter-pays principle by the Federal Supreme Court (STF) and Superior Court of Justice (STJ) in Brazil. The main objective was to analyze critically how this principle - considering its historical origin, relevance and extent - has had an impact on the case law regarding the legal protection of the environment, according to the search for the effectiveness of the fundamental right to a balanced environment. The study comprised a bibliographical and documentary survey, along with cataloging and critical analysis of the selected material; the methodology included a survey, systematization and qualitative analysis of decisions pronounced by the Courts in the period from 1993 to 2018 within the scope of STF and STJ. In relation to its reparatory dimension, it was possible to observe that the polluter-pays principle has played an important role in improving environmental civil liability, as a theoretical guideline for the solution of several of the challenges to the full reparation of environmental damages. As to the preventive dimension of this principle, which is equally relevant for the better application of tools that promote distributive justice in environmental matters, it was possible to verify its significant underutilization.

Keywords: Polluter-pays principle; negative environmental externality; internalization of environmental costs; prevention and remedying of environmental damage; civil environmental liability. 


\section{INTRODUÇÃO}

O processo de coletivização e despatrimonialização por que passaram os ordenamentos jurídicos ao longo do século XX resultou em significativas mudanças nos objetivos e papeis representados pelo Direito, que, para além de solucionar conflitos, passou a ter como primordial função a promoção da justiça social. A proteção constitucional do meio ambiente é uma das expressões deste processo de expansão do conteúdo dos direitos humanos. O direito ao meio ambiente é reconhecido como direito humano e fundamental, de titularidade difusa e intergeracional. No âmbito dos direitos humanos de terceira geração ou direitos fundamentais de terceira dimensão, associa-se, como não poderia deixar de ser, a garantia do direito à vida digna à manutenção do meio ambiente equilibrado. Evidente é, portanto, a conotação existencial e coletiva deste direito, cuja construção se dá a partir da reação da sociedade à crise ambiental.

$\mathrm{O}$ amadurecimento do sistema jurídico-ambiental, impulsionado pela constitucionalização da proteção jurídica do meio ambiente, resulta na constatação de que o Direito Ambiental, enquanto ramo autônomo do Direito, tem como um de seus papeis essenciais a promoção da justiça distributiva em matéria ambiental, tendo em vista a garantia da qualidade de vida para as presentes e futuras gerações.

Neste contexto, ganha destaque o princípio do poluidorpagador (PPP), voltado para a internalização dos custos ambientais no funcionamento de atividades potencialmente poluidoras. À luz deste princípio, pretende-se que as externalidades ambientais negativas - ou, em outras palavras, os custos ambientais externos - sejam computados como custos de produção. A promoção da justiça distributiva ambiental depende do reconhecimento de que cabe principalmente ao poluidor - ou potencial poluidor - arcar com os custos preventivos e reparatórios decorrentes da degradação ambiental por ele gerada ou que ele é capaz de gerar.

Reconhecida a importância e o potencial - muitas vezes subestimado - do princípio do poluidor-pagador como um dos alicerces do Direito Ambiental, fortalecem-se os diversos instrumentos jurídicoambientais dedicados a promover a distribuição equitativa dos ônus e bônus socioambientais, com o objetivo de concretizar o direito de todos ao meio ambiente ecologicamente equilibrado, nos termos do artigo 225 da Constituição Federal de 1988.

Este texto apresenta os resultados de pesquisa desenvolvida em 
2014, e atualizada em 2017 e 2018, cujo principal objetivo foi o de analisar criticamente como o princípio do poluidor-pagador - considerada a sua origem histórica e o reconhecimento de sua importância e amplitude - tem sido aplicado na jurisprudência brasileira, em especial nos julgamentos de casos que tratam de questões relativas à tutela jurídica do meio ambiente no âmbito do Supremo Tribunal Federal (STF) e do Superior Tribunal de Justiça (STJ), tendo em vista a busca pela efetividade do direito fundamental ao meio ambiente ecologicamente equilibrado.

O estudo compreendeu levantamento bibliográfico e documental, acompanhado de catalogação e análise crítica do material selecionado; a metodologia adotada incluiu levantamento, sistematização e análise qualitativa de acórdãos julgados no período de 1993 a 2018 no âmbito do STF e STJ. Parte-se do embasamento teórico que sustenta e conduz a demonstração da relevância e a identificação do alcance do PPP para a identificação de como os julgados selecionados traduzem a orientação do princípio em questão, em suas dimensões preventiva e reparatória. Esperase que este estudo contribua para o aperfeiçoamento da tutela jurídicoambiental brasileira e, de modo mais específico, para que a orientação do referido princípio seja melhor compreendida pelos tribunais.

\section{O PRINCÍPIO DO POLUIDOR-PAGADOR: ORIGEM E CARACTERÍSTICAS}

O princípio do poluidor-pagador, diretriz basilar do Direito Ambiental, surgiu em contexto e com objetivo diverso do entendimento e alcance que possui hoje. Se atualmente é entendido como um princípio geral do Direito Ambiental, em seu despertar, fora pensado como premissa essencialmente econômica, objetivando a alocação adequada de custos por meio da internalização das externalidades ambientais negativas. ${ }^{2}$

Em 1972, o princípio do poluidor-pagador recebeu a atenção da Organização para Cooperação e Desenvolvimento Econômico (OCDE) e foi incorporado em sua Recomendação sobre Princípios Relacionados aos Aspectos Econômicos Internacionais das Políticas Ambientais (C(72) 128 , de 26.05.1972). Neste primeiro documento, atribuiu-se ao poluidor apenas os custos de prevenção da poluição. A ampliação do conceito para internalização também dos custos relativos aos danos ambientais foi posterior, inicialmente no âmbito da própria OCDE, em suas recomendações

2 Sobre o assunto, cf. MOREIRA, 2015b, p. 85 -95. 
posteriores relativas ao PPP.

Desde o início da década de 1970, o princípio do poluidorpagador percorreu longo caminho. Na Europa, em 1986, o Ato Único Europeu (art. 130 R) identificou o PPP como um dos princípios em que se alicerça a política comunitária. Em 1992, por ocasião da Conferência das Nações Unidas sobre Meio Ambiente e Desenvolvimento (Rio 92), houve a assinatura da Declaração do Rio, que em sua lista de princípios enumerou o poluidor-pagador como princípio de número 16.

Com a ampliação do conteúdo do princípio do poluidorpagador, ultrapassada sua conotação meramente econômica, e a gradativa conscientização a nível global da problemática ambiental, pode-se dizer que o PPP tem como orientação a responsabilidade do poluidor (ou potencial poluidor) pelos custos de proteção do meio ambiente relacionados à prevenção e à reparação da poluição por ele gerada (ou potencialmente gerada). Herman Benjamin observa que o princípio em questão compreende a internalização de todos os custos da poluição (BENJAMIN, 1993, p. 231), tendo em vista a conscientização do real valor dos bens ambientais.

No Direito brasileiro, o princípio do poluidor-pagador foi incorporado na Política Nacional do Meio Ambiente (Lei 6.938/1981, art. $4^{\circ}$, VII) e fundamentou a adoção, pela mesma lei, da responsabilidade civil ambiental objetiva, tornando irrelevante a culpa do poluidor para que este seja responsabilizado pela reparação de danos ambientais (art. 14, $\S 1^{\circ}$ ). A orientação do PPP também é identificada na Constituição Federal de 1988 , em especial à luz de seus artigos 170 , VI, e 225, parágrafos $2^{\circ}$ e $3^{\circ}$. Deve-se dizer que, embora apenas a vocação reparatória do PPP conste explicitamente referenciada (BENJAMIN, 1993, p. 232), sua dimensão preventiva é implicitamente identificada, especialmente a partir da leitura do artigo 170, VI, que dispõe sobre a defesa do meio ambiente, "inclusive mediante tratamento diferenciado conforme o impacto ambiental dos produtos e serviços e de seus processos de elaboração e prestação", como princípio conformador da ordem econômica brasileira.

Trata-se de princípio com vocação redistributiva, ou seja, muito além de combater as falhas de mercado, destina-se a promover a justiça distributiva em matéria ambiental, mediante adequada alocação de custos ambientais dentro da cadeia de produção e consumo, alcançando cada um de seus elos. Quando há a alocação adequada dos custos ambientais externos aos processos produtivos, os responsáveis pelo impacto ou pelo dano ambiental - ainda que potenciais - devem arcar com os respectivos 
custos de prevenção ou de reparação, de modo que a coletividade não suporte os ônus relativos à poluição. A equitativa distribuição de ônus ambientais nas cadeias de produção e consumo é o que se convencionou chamar de internalização das externalidades ambientais negativas. ${ }^{3} \mathrm{O}$ que se pretende é evitar a chamada "socialização dos ônus e privatização dos bônus", presente sempre que as externalidades negativas são suportadas pela coletividade ao invés de arcadas por quem originalmente as produziu. É importante salientar que não se trata de compra do "direito de poluir". O que se busca com a internalização dos custos socioambientais é promover a justiça distributiva em matéria ambiental, e aumentar o grau de conscientização sobre a questão, de modo que as atividades econômicas sejam mais responsáveis e menos impactantes (RODRIGUES, 2005, p. 232). Para Nicolas de Sadeleer, o poluidor não pode pensar que, se paga, tem o direito de poluir, o que seria distorcer o princípio em "pagadorpoluidor", ao invés de "poluidor-pagador" (SADELEER, 1999, p. 66 e 67). ${ }^{4}$

Neste sentido, ao se falar em internalização de custos ambientais externos aos processos produtivos, quer-se dizer que as despesas relativas à prevenção da poluição e à reparação de eventuais danos ambientais (ou, mesmo, a compensação por impactos ambientais toleráveis e, por isso, autorizados) devem ser suportadas pelo poluidor (ou potencial poluidor). A função preventiva do PPP manifesta-se ao impelir o potencial poluidor a adotar medidas eficazes - e arcar com seus respectivos custos - para evitar

\footnotetext{
3 A respeito das externalidades ambientais negativas, cf. MOREIRA, 2015b, p. 95-116. As externalidades ambientais podem ser positivas ou negativas e são geradas pelas falhas de mercado. Estas ocorrem pela falta de valoração no mercado dos recursos naturais, tradicionalmente considerados como de livre uso - e abuso, pode-se dizer. O mercado gera distorções quando não reconhece e traduz adequadamente os custos ambientais inerentes à produção e ao consumo. Quando um agente poluidor não internaliza os custos relacionados à prevenção ou reparação do impacto ou dano causado, o produto não apresenta, no mercado, o preço real de sua produção (SILVA FILHO, 2008, p. 82 - 87). A externalidade ambiental negativa pode ser facilmente compreendida no exemplo trazido por Herman Benjamin: "Suponha-se que a pintura de uma casa, localizada ao lado de uma indústria poluidora, seja danificada pela fumaça negra. Num modelo jurídico (e econômico) tradicional, a conta da repintura da casa é paga pelo seu proprietário e não por aquele que, de fato, causou o dano. Em consequência, os produtos eventualmente fabricados pelo poluidor - já que este nada está pagando pela sua atividade poluidora não refletirão os custos reais da poluição. Fala-se, então, que tais custos, porque não computados no processo de produção, são uma externalidade ou custo externo". (BENJAMIN, 1993, p. 229).

4 Para Marcelo Abelha Rodrigues, "o axioma poluidor/usuário-pagador não pode ser interpretado ao pé da letra, tendo em vista que não traduz a ideia de "pagar para poluir", ou de "pagar pelo uso", especialmente também porque o seu alcance é absurdamente mais amplo do que a noção meramente repressiva que possui. Muitas vezes tomado como "pago para poder poluir", o princípio do poluidor pagador passa muito longe desse sentido, não só porque o custo ambiental não encontra valoração pecuniária correspondente, mas também porque a ninguém poderia ser dada a possibilidade de comprar o direito de poluir, beneficiando-se do bem ambiental em detrimento da coletividade que dele é titular". (RODRIGUES, 2005, p. 190).
} 
que ocorra a degradação ambiental. Já a faceta reparatória - ou, nas palavras de Nicolas de Sadeleer, a função curativa (SADELEER, 1999, p. 69) - do PPP pode ser concretizada, por exemplo, por meio da responsabilidade civil ambiental, partindo-se da premissa de que o dano ambiental é uma externalidade ambiental negativa, vez que se traduz em custos ambientais externos - sofridos por outsiders - aos processos produtivos. A este respeito, pontua-se que boa parte dos autores estrangeiros discorda deste entendimento, a exemplo de Maria Alexandra Aragão, que não reconhece a responsabilidade civil como expressão do princípio em análise (ARAGÃO, 1997, p. 118 e ss.). Por outro lado, a maioria dos autores brasileiros acaba por associar quase que automaticamente o PPP à responsabilidade civil, como se fossem sinônimos, identificando, de forma limitada, apenas a vocação reparatória do princípio. ${ }^{5}$

Além da amplitude da orientação do PPP, é necessário definir quem é o poluidor responsável pela internalização das externalidades ambientais negativas; ou seja, quem pode ser chamado a adotar medidas - e arcar com as respectivas despesas - destinadas a evitar e reparar a degradação ambiental. ${ }^{6}$ Nos termos da Lei da Política Nacional do Meio Ambiente, são poluidoras as pessoas físicas ou jurídicas responsáveis direta ou indiretamente ${ }^{7}$ por atividade degradadora da qualidade ambiental. ${ }^{8}$

De acordo com Herman Benjamin, "o poluidor, então, passa a ser o primeiro pagador” (BENJAMIN, 1993, p. 229). É ele o responsável principal pela internalização dos custos ambientais externos aos processos produtivos. O consumidor, em última análise, não pode ser o responsável principal, tendo em vista que além de não ter meios concretos para evitar ou reparar o dano (ou para compensar o impacto), suportará - em razão do efeito "cascata" ou "dominó" - os custos referentes à internalização que o agente responsável pela geração das externalidades inserir no preço do produto ou serviço (SADELEER, 1999, p. 83).

5 Sobre esta questão, cf. MOREIRA, 2015b, p. 103 a 116.

6 Quanto ao pagamento, entende-se que ao poluidor cabem todos os custos relacionados à poluição por ele gerada ou que ele seja capaz de gerar. (BENJAMIN, 1993, p. 231).

7 Não se pretende, neste artigo, explorar as dificuldades relativas à definição do poluidor indireto, vez que não se trata de tema necessário à análise jurisprudencial desenvolvida. De todo modo, destaca-se que a "condição de "poluidor-que-deve-pagar" é atribuída, portanto, ao produtor, seja como poluidor direto seja como poluidor indireto. Como poluidor direto, o produtor é quem efetivamente cria e controla as condições em que a poluição é produzida, "sua actuação foi condição sine qua non da poluição, e só ele dispõe de meios para evitar". Já na qualidade de poluidor indireto, o produtor é quem cria e controla as condições que vão desencadear a poluição, além de lucrar com elas; é o produtor quem coloca no mercado um bem cuja utilização normal e provável é tida como prejudicial a toda a sociedade". (MOREIRA, 2015b, p. 109).

8 Art. $3^{\circ}$, III e IV da Lei 6.938/1981. 
O princípio do poluidor-pagador, se efetivamente aplicado, funciona como um mecanismo de redução da poluição (MOREIRA, 2015b, p. 91). Sua completude se dá no momento em que, internalizados pelo poluidor, os custos de prevenção e reparação não recaiam sobre a coletividade e os danos sejam evitados. Assim, garante-se que haja responsabilidade por parte dos poluidores e, em consequência, promove-se o equilíbrio do mercado, a conscientização de produtores e consumidores, o estímulo a avanços tecnológicos e o fomento a atitudes preventivas mais sedutoras no contexto de precisa alocação de custos e responsabilidades. E, como consequência, espera-se que a aplicação do PPP promova a redução das iniquidades ambientais existentes num cenário de privatização de bônus e socialização de ônus.

A compreensão das funções - preventiva e reparatória - do princípio do poluidor-pagador é fundamental para que se identifique a abrangência e o potencial de sua orientação para a proteção ambiental, e, consequentemente, para que se verifique de que forma tem sido considerado e aplicado no julgamento de ações ambientais. O que se apresenta, a seguir, é um diagnóstico de como o PPP tem orientado as decisões judiciais e em que medida tem contribuído para o aperfeiçoamento da tutela jurídicoambiental brasileira.

\section{RESULTADOS DA PESQUISA NA JURISPRUDÊNCIA DO STF E DO STJ}

Foram pesquisados acórdãos do Supremo Tribunal Federal (STF) e do Superior Tribunal de Justiça (STJ) com o objetivo de analisar a incidência do princípio do poluidor-pagador e se sua aplicação está de acordo com as transformações e a abrangência do princípio, tendo sido selecionadas as seguintes palavras-chave, que expressam ou traduzem as orientações - preventiva e reparatória - do PPP: "poluidor e pagador", "poluidor-pagador", "externalidade", "externalidade e ambiental e negativa", "usuário e pagador", "usuário-pagador", "internalização e ambiente", "internalização e ambiental", "custos e ambiente", "custos e ambiental", "dano e ambiente", "dano e ambiental", "responsabilidade e civil e ambiental", "degradação e ambiente" e "degradação e ambiental".

A pesquisa jurisprudencial, realizada em 24.03.2014 e atualizada em 31.07.2017 e em 25.04.2018, levantou o total de 2.701 acórdãos, julgados no período entre 1993 e 2018 . Foi observado significativo aumento 
da quantidade de julgados a cada ano de atualização do levantamento jurisprudencial. A tabela a seguir, apresenta o número total de ocorrências das palavras-chave em acórdãos cujas ementas foram lidas e examinadas de modo a identificar sua pertinência temática com o PPP.

\section{Relação entre palavras-chave e incidências no total de acórdãos pesquisados em 2014 e atualizados em 2017 e 2018}

\begin{tabular}{|l|l|l|l|l|l|l|}
\hline \multirow{2}{*}{ Palavras-chave } & \multicolumn{2}{|l|}{ Ocorrências no STF } & \multicolumn{3}{l}{ Ocorrências no STJ } \\
\cline { 2 - 8 } & $\mathbf{2 0 1 4}$ & $\mathbf{2 0 1 7}$ & $\mathbf{2 0 1 8}$ & $\mathbf{2 0 1 4}$ & $\mathbf{2 0 1 7}$ & $\mathbf{2 0 1 8}$ \\
\hline Poluidor e pagador & 1 & 1 & 1 & 23 & 28 & 31 \\
\hline Poluidor-pagador & 0 & 0 & 0 & 22 & 26 & 29 \\
\hline Externalidade & 0 & 0 & 0 & 3 & 5 & 5 \\
\hline $\begin{array}{l}\text { Externalidade e ambiental e } \\
\text { negativa }\end{array}$ & 0 & 0 & 0 & 3 & 3 & 3 \\
\hline Usuário e pagador & 1 & 1 & 1 & 3 & 5 & 6 \\
\hline Usuário-pagador & 1 & 1 & 1 & 2 & 3 & 4 \\
\hline Internalização e ambiente & 0 & 0 & 0 & 1 & 1 & 1 \\
\hline Internalização e ambiental & 0 & 0 & 0 & 1 & 1 & 1 \\
\hline Custos e ambiente & 1 & 3 & 3 & 29 & 35 & 35 \\
\hline Custos e ambientais & 1 & 2 & 2 & 6 & 6 & 7 \\
\hline Dano e ambiente & 42 & 71 & 73 & 601 & 856 & 930 \\
\hline Dano e ambiental & 52 & 98 & 104 & 548 & 901 & 1.003 \\
\hline Responsabilidade e civil e & 22 & 41 & 45 & 187 & 301 & 342 \\
\hline ambiental & 9 & 10 & 10 & 91 & 132 & 141 \\
\hline Degradação e ambiente & 9 & 11 & 13 & 103 & 152 & 163 \\
\hline Tegradação e ambiental & 239 & 253 & 1.623 & 2.455 & 2.701 \\
\hline
\end{tabular}

Fonte: autoras 
A partir da leitura e análise das ementas dos 2.701 julgados levantados, foi possível descartar aqueles que, apesar de resultarem de busca a partir das palavras-chave escolhidas, não apresentam conexão com o princípio do poluidor-pagador. Deste total de julgados levantados e sistematizados na pesquisa atualizada em 2018, foram selecionados 208 acórdãos, considerados pertinentes ao tema e analisados em seus textos integrais. A seguir, os resultados numéricos obtidos após a referida filtragem.

\section{Resultados numéricos após filtragem qualitativa}

\begin{tabular}{|c|c|}
\hline \multicolumn{2}{|c|}{ Acórdãos selecionados para análise do inteiro teor } \\
\hline 2014 & 110 \\
\hline 2017 & 183 \\
\hline 2018 & 208 \\
\hline
\end{tabular}

Fonte: autoras

Para observar como a orientação do PPP tem impactado nas decisões judiciais relativas à tutela jurídica do meio ambiente, foi realizada a leitura do inteiro teor dos 208 acórdãos considerados relevantes à análise. A partir da análise da incidência do princípio nesses casos, foi possível sua categorização temática conforme a tabela a seguir. ${ }^{9}$ A priorização do campo da responsabilidade civil ambiental no enquadramento por grupo temático se dá em razão da numerosa quantidade de julgados relativos à reparação de danos ambientais e seus principais desafios.

\section{Incidência do PPP por grupo temático}

\begin{tabular}{|l|l|l|}
\hline \multicolumn{2}{|c|}{ ENQUADRAMENTO POR GRUPO TEMÁTICO } & ACÓRDÃOS \\
\hline G1 & Responsabilidade civil ambiental geral & 110 \\
\hline G2 & Dano ambiental extrapatrimonial e teoria do risco integral & 41 \\
\hline G3 & Responsabilidade civil ambiental do Estado por omissão & 19 \\
\hline G4 & Possibilidade de cumulação de obrigação de fazer e de pagar & 39 \\
\hline
\end{tabular}

9 Dentre os 208 acórdãos considerados pertinentes ao tema desta pesquisa e selecionados para análise do inteiro teor, 12 foram alocados em mais de um grupo temático, dentre os grupos G1 a G6. Sendo assim, a soma dos resultados por grupo não representa o total de acórdãos analisados, mas o número de acórdãos alocados por grupo, o que resulta num total de 220 . O anexo com todos os acórdãos analisados, separados por grupo, faz a discriminação daqueles repetidos. 


\begin{tabular}{|l|l|l|}
\hline G5 & $\begin{array}{l}\text { Compensação ambiental do Sistema Nacional de Unidades de } \\
\text { Conservação (SNUC) }\end{array}$ & 2 \\
\hline G6 & Responsabilidade administrativa ambiental & 9 \\
\hline
\end{tabular}

Fonte: autoras

Tendo em vista os enquadramentos temáticos identificados nos acórdãos selecionados, apresentam-se, a seguir, as análises empreendidas com base em suas respectivas correspondências com a ampla orientação do princípio do poluidor-pagador.

\subsection{Responsabilidade civil ambiental geral: Grupo 1}

Este grupo abrange um total de 110 acórdãos. De acordo com a tabela 1, anexa, é possível observar que dentre todos os acórdãos, apenas em dois aparece a expressão "poluidor-pagador", enquanto nos outros aparecem abundantemente as palavras-chave "dano e ambiente", "dano e ambiental" e "responsabilidade e civil e ambiental".

$\mathrm{O}$ recorte da tabela anterior, que aponta a incidência do PPP por grupo temático, para identificação dos acórdãos alocados no Grupo 1 (responsabilidade civil ambiental geral), e seus desdobramentos são apresentados a seguir.

Julgados alocados no Grupo 1 (responsabilidade civil ambiental geral)

\begin{tabular}{|c|c|c|c|c|}
\hline GRUPO & ANOS & TURMAS & PALAVRAS-CHAVE & $\begin{array}{l}\text { NÚMERO } \\
\text { D } \\
\text { ACORDÃOS }\end{array}$ \\
\hline $\begin{array}{l}\text { G1 } \\
\text { Responsabilidade } \\
\text { civil ambiental } \\
\text { geral }\end{array}$ & $\begin{array}{l}1993 \mathrm{a} \\
2018\end{array}$ & $\begin{array}{l}1^{\mathrm{a}} \text { a } 5^{\mathrm{a}} \\
\text { Turmas do } \\
\text { STJ }\end{array}$ & $\begin{array}{l}\text { dano e ambiente/ dano e } \\
\text { ambiental/ responsabilidade } \\
\text { e civil e ambiental/ } \\
\text { degradação e ambiente/ } \\
\text { degradação e ambiental/ } \\
\text { custos e ambiente/custos } \\
\text { e ambiental/ poluidor- } \\
\text { pagador/ poluidor e pagador }\end{array}$ & 110 \\
\hline
\end{tabular}

Fonte: autoras 
Dentro do G1 surgiram diferentes subtemas atrelados ao conceito da responsabilidade civil ambiental geral e que serão apresentados em conjunto, de acordo com suas características, e com referências a alguns dos julgados, a título exemplificativo.

Amaioria dos acórdãos refere-se expressamenteàresponsabilidade civil ambiental objetiva, abordando seus conceitos, fundamentação legal e interpretação tanto pela doutrina como pelos tribunais.

A Política Nacional do Meio Ambiente, Lei 6.939/81, em seu artigo 14 , parágrafo $1^{\mathrm{o}},{ }^{10}$ já previa a responsabilidade civil objetiva do poluidor (art. $\left.3^{\circ}, I V\right)^{11}$ por danos causados ao meio ambiente e a terceiros, tornando irrelevante a subjetividade da conduta do agente para que haja a obrigação de reparação dos danos ambientais. Esta previsão legal foi recepcionada pelo artigo 225, parágrafo $3^{\circ}$, da Constituição Federal. ${ }^{12}$ Exemplificativamente, cita-se o Recurso Especial 1.346.449-PR,,$^{13} \mathrm{em}$ que, com base nos dispositivos mencionados, se afirmou que ao empreendedor impõe-se a "obrigação de prevenir tais riscos [ambientais] (princípio da prevenção) e de internizá-los em seu processo produtivo (princípio do poluidor-pagador)".

Outro julgado interessante é o do Agravo Regimental no Recurso Especial 1.121.233-SP, ${ }^{14}$ em que se analisou a pretensão de reforma de acórdão que condenou a Petrobras a pagar multa diária por lançar gás tóxico no meio ambiente, além de ter que tomar todas as medidas possíveis e cabíveis para a prevenção e controle daquelas emissões, fazendo frente ao dano ambiental de modo a garantir sua prevenção e reparação. Esta decisão, ainda que não tenha mencionado expressamente o PPP, manifesta, além da faceta reparatória, sua dimensão preventiva, identificada na imposição expressa de adoção de medidas destinadas a prevenir e controlar a causa da poluição.

10 "Sem obstar a aplicação das penalidades previstas neste artigo, é o poluidor obrigado, independentemente da existência de culpa, a indenizar ou reparar os danos causados ao meio ambiente e a terceiros, afetados por sua atividade".

11 É “poluidor, a pessoa física ou jurídica, de direito público ou privado, responsável, direta ou indiretamente, por atividade causadora de degradação ambiental".

12 "As condutas e atividades consideradas lesivas ao meio ambiente sujeitarão os infratores, pessoas físicas ou jurídicas, a sanções penais e administrativas, independentemente da obrigação de reparar os danos causados".

13 STJ. $4^{\mathrm{a}}$ Turma. Recurso Especial 1.346.449-PR, Rel. Min. Luis Felipe Salomão. Brasília. DJ $08 / 10 / 2012$.

14 STJ. $1^{\text {a }}$ Turma. Recurso Especial 282.781-PR, Rel. Min. Arnaldo Esteves Lima. Brasília. DJ $02 / 02 / 2011$. 
Subtema que aparece em significativo número de acórdãos ${ }^{15}$ é o que diz respeito à responsabilidade do novo adquirente pela recomposição de vegetação protegida ou reparação de dano pré-existente em propriedade adquirida já degradada. Boa parte dos casos versa sobre dano ambiental em imóvel que contém em seus limites áreas de preservação permanente ou de reserva legal, cujo proprietário anterior foi o responsável direto pelo dano. O principal argumento de defesa dos proprietários foi o de que faltaria legitimidade ao novo adquirente para ser responsabilizado pelo dano diretamente causado pelo antigo proprietário; não haveria nexo de causalidade entre conduta atribuível ao novo proprietário e a degradação ocorrida.

A este respeito, o STJ pacificou o entendimento de que a obrigação de manutenção da incolumidade da propriedade (por exemplo, com a manutenção de áreas ambientalmente protegidas) é propter rem, sendo possível responsabilizar o atual proprietário por danos ambientais existentes na propriedade, mesmo que estes danos tenham sido provocados diretamente por condutas de antigos proprietários. ${ }^{16}$ Além do argumento com base na obrigação propter rem, considera-se que o novo adquirente, ao permitir a perpetuação do dano ambiental em sua propriedade, ainda que não tenha agido comissivamente para sua causação inicial, passa a integrar

15 STJ. $2^{\text {a }}$ Turma. Recurso Especial 217.858-PR, Rel. Min. Franciulli Netto. Brasília. DJ 04/11/2003; STJ. $2^{\text {a }}$ Turma. Recurso Especial 264.173-PR, Rel. Min. José Delgado. DJ 15/02/2001; STJ. $2^{\text {a }}$ Turma. Recurso Especial 343.741-PR, Rel. Min. Franciulli Netto. DJ 04/06/2008; STJ. $2^{\text {a }}$ Turma. Recurso Especial 453.875-PR, Rel. Min. Herman Benjamin. DJ 18/10/2007; STJ. $2^{\mathrm{a}}$ Turma. Recurso Especial 1.056.540-GO, Rel. Min. Eliana Calmon. DJ 25/08/2009; STJ. $1^{\text {a }}$ Turma. Recurso Especial 1.090.968-SP, Rel. Luiz Fux. DJ 15/06/2010; STJ. 2 a Turma. Recurso Especial 1.237.071-PR, Rel. Min. Humberto Martins. Brasília. DJ 11/05/2011; STJ. $2^{\mathrm{a}}$ Turma. Recurso Especial 1.206.484-SP, Rel. Min. Humberto Martins. Brasília. DJ 29/03/2011; STJ. 2a Turma. Recurso Especial 327.254-PR, Rel. Min. Eliana Calmon. Brasília. DJ 19/12/2002; STJ. 2a Turma. Recurso Especial 282.781-PR, Rel. Min. Eliana Calmon. Brasília. DJ 27/05/2002; STJ. 2 ${ }^{\mathrm{a}}$ Turma. Recurso Especial 1.622.512-RJ, Rel. Min. Herman Benjamin. Brasília. DJ 22/09/2016; STJ. 2a Turma. Recurso Especial 1.644.195-SC, Rel. Min. Herman Benjamin. DJ 27/04/2017; STJ. 2a Turma. Recurso Especial 1.241.630-PR, Rel. Min. Herman Benjamin. DJ 23/06/2015; STJ. ${ }^{\text {a }}$ Turma. Recurso Especial 282.781-PR, Rel. Min. Luiz Fux. Brasília. DJ 18/10/2007; STJ. $2^{a}$ Turma. Agravo Regimental em Agravo no Recurso Especial 231.561-MG, Rel. Min. Herman Benjamin. Brasília. DJ 16/12/2014; STJ. 5a Turma. Recurso em Habeas Corpus 64.124MS, Rel. Min. Reynaldo Soares da Fonseca. Brasília. DJ 17/03/2016; STJ. $5^{\text {a }}$ Turma. Recurso em Habeas Corpus 64.219-MS, Rel. Min. Reynaldo Soares da Fonseca. Brasília. DJ 17/03/2016.

16 Cf., por exemplo, STJ. $2^{\text {a }}$ Turma. Recurso Especial 948.921-SP, Rel. Min. Herman Benjamin. DJ $11 / 11 / 2009$.

Veja-se, ainda, que por ocasião do julgamento do Recurso Especial 229.302-PR (STJ. $1^{\text {a }}$ Turma, Rel. Min. Garcia Vieira. DJ 18/11/1999), ainda não estava consolidado o entendimento de que o novo adquirente é responsável pela reparação do dano ambiental existente em sua propriedade, independentemente de ter dado causa a ele. À época, entendeu-se não ser possível estabelecer nexo causal entre a conduta do novo proprietário e o desmatamento da área e, por consequência, afastou-se sua obrigação de recuperar o dano. Felizmente, conforme demonstram os diversos julgados aqui citados, tal entendimento foi superado. Atualmente, a responsabilidade do novo adquirente encontra-se prevista de modo expresso no Novo Código Florestal (Lei 12.651/2012), nos termos do artigo $7^{\circ}$, parágrafos $1^{\circ}$ e $2^{\circ}$. 
o amplo rol de poluidores (art. $3^{\circ}$, IV, Lei 6.938/1981), responsáveis pela reparação independentemente de culpa. ${ }^{17}$

Vê-se que, apesar de não expressa de modo explícito no texto dos julgados, a orientação do PPP fica evidente em seu caráter reparatório, advindo da necessidade de restauração da área degradada - com a necessária assunção dos respectivos custos -, independentemente de culpa, conforme apregoa a responsabilidade civil ambiental objetiva.

Outra questão que aparece em alguns dos julgados selecionados é a referente à imprescritibilidade da pretensão de reparação do dano ambiental. Tratam do assunto os acórdãos referentes ao Recurso Especial 1.559.396-MG ${ }^{18}$ ao Agravo Regimental no Recurso Especial 1.421.163$\mathrm{SP}^{19}$ e aos Embargos de Declaração no Recurso Especial 1.346.489-RS. ${ }^{20}$ Os casos dizem respeito a: (i) irregularidades em áreas verdes pertencentes ao município, (ii) edificação em área de preservação permanente (APP) com consequente contaminação do solo e do lençol freático, e (iii) contaminação da área por produtos químicos utilizados no tratamento de madeira destinada à fabricação de postes de luz. Em todos estes casos houve a condenação na obrigação de reparar o dano causado, tendo sido consideradas imprescrítiveis as ações coletivas propostas, por tratarem de questão relativa a direito inerente à vida, fundamental, indisponível e inalienável, bem como em razão do caráter continuado das lesões ao meio ambiente (MAZZILI, 2002, p. 540). ${ }^{21}$

17 Neste sentido, lê-se em um dos julgados que "no que tange às alegações de sua ausência de legitimidade e de responsabilidade pelo dano ambiental, entendo que não merecem prosperar, porquanto essa, como proprietária da área em questão, possui absoluta legitimidade ad causam para figurar no polo passivo da presente demanda, não sendo o fato de já ter adquirido o terreno com as construções causadoras do dano um óbice, pois tornou-se também responsável pelo passivo ambiental quando da aquisição, assumindo uma responsabilidade objetiva solidária e propter rem, detendo o dever de manter o meio ambiente equilibrado na área de preservação permanente e, na hipótese de encontrá-lo devastado, de reconstituí-lo, o que inocorreu no caso concreto". (STJ. 1ª Turma. Recurso Especial 843.036-PR, Rel. Min. José Delgado. DJ 09/11/2006).

18 STJ. $2^{a}$ Turma. Recurso Especial 1.559.396-MG, Rel. Min. Herman Benjamin. DJ 22/11/2016.

19 STJ. $2^{\text {a }}$ Turma. Agravo Regimental no Recurso Especial 1.421.163-SP, Rel. Min. Humberto Martins. DJ 06/11/2014.

20 STJ. $3^{\text {a }}$ Turma. Embargos de declaração no Recurso Especial 1.346.489-RS, Rel. Min. Ricardo Villas Bôas Cueva. DJ 11/06/2013.

21 Sobre o assunto, lê-se em trecho da ementa do acordão do Recurso Especial 1.120.117-AC:

"4. O dano ambiental além de atingir de imediato o bem jurídico que lhe está próximo, a comunidade indígena, também atinge a todos os integrantes do Estado, espraiando-se para toda a comunidade local, não indígena e para futuras gerações pela irreversibilidade do mal ocasionado.

5. Tratando-se de direito difuso, a reparação civil assume grande amplitude, com profundas implicações na espécie de responsabilidade do degradador que é objetiva, fundada no simples risco ou no simples fato da atividade danosa, independentemente da culpa do agente causador do dano.

6. O direito ao pedido de reparação de danos ambientais, dentro da logicidade hermenêutica, está protegido pelo manto da imprescritibilidade, por se tratar de direito inerente à vida, fundamental e essencial à afirmação dos povos, independentemente de não estar expresso em texto legal. 
Discussão sobre a imposição da obrigação de reparação ambiental nos casos em que há fato consumado é identificada em vários dos acordãos do Grupo $1,{ }^{22}$ que versam sobre construções em APP, antecedidas pela supressão quase total da vegetação protegida. A defesa dos réus baseouse substancialmente no argumento de que haveria direito adquirido, sob a alegação de que as edificações estariam consolidadas no tempo, além da tese de que as obras teriam tido, à época, licença ambiental autorizando sua realização. Não foi este o entendimento que prevaleceu, vez que se considerou que o fato de ter ocorrido a consolidação da situação no tempo não torna as obras realizadas menos ilegais. Até porque, neste contexto, uma vez comprovada a construção em APP, deve-se reconhecer a ilegalidade do ato administrativo que concedeu a licença ambiental. Ademais, a concessão de licença ambiental não afasta, por si só, a responsabilidade pela reparação de dano causado ao meio ambiente.

Neste sentido, Herman Benjamin afirma inexistir direito adquirido a poluir ou degradar o meio ambiente, dado que "décadas de uso ilícito do meio ambiente não tornam legais práticas vedadas pelo legislador", devendo-se lembrar que se está tratando de direito difuso, indisponível, pertencente também às gerações futuras. ${ }^{23}$ Neste mesmo sentido, afirmase que a "teoria do fato consumado não pode ser invocada para conceder direito inexistente sob a alegação de consolidação da situação fática pelo decurso do tempo". ${ }^{24}$

Veja-se que a questão deu origem à publicação, em 14/05/2018, da Súmula 613 do STJ, segundo a qual "não se admite a aplicação da teoria do fato consumado em tema de Direito Ambiental”. A aceitação da teoria do

\footnotetext{
7. Em matéria de prescrição cumpre distinguir qual o bem jurídico tutelado: se eminentemente privado seguem-se os prazos normais das ações indenizatórias; se o bem jurídico é indisponível, fundamental, antecedendo a todos os demais direitos, pois sem ele não há vida, nem saúde, nem trabalho, nem lazer, considera-se imprescritível o direito à reparação.

8. O dano ambiental inclui-se dentre os direitos indisponíveis e como tal está dentre os poucos acobertados pelo manto da imprescritibilidade [sic] a ação que visa reparar o dano ambiental." (STJ. 2 ${ }^{\mathrm{a}}$ Turma. Recurso Especial 1.120.117-AC, Rel. Min. Eliana Calmon. DJ 10/11/2009).

22 STJ. $2^{\mathrm{a}}$ Turma. Agravo Regimental no Recurso Especial 1.494.681-MS, Rel. Min. Humberto Martins. DJ 03/11/2015; STJ. 2a Turma. Agravo Regimental no Recurso Especial 1.494.988-MS, Rel. Min. Humberto Martins. DJ 01/10/2015; STJ. 2 ${ }^{\mathrm{a}}$ Turma. Agravo Interno no Recurso Especial 1.382.576MS, Rel. Min. Assusete Magalhães. DJ 13/06/2017; STJ. $2^{\text {a }}$ Turma. Agravo Interno nos Embargos de Declaração no Recurso Especial 1.447.071-MS, Rel. Min. Herman Benjamin. DJ 15/12/2016; STJ. 2 ${ }^{\mathrm{a}}$ Turma. Agravo Interno nos Embargos de Declaração no Recurso Especial 1.468.747-MS, Rel. Min.

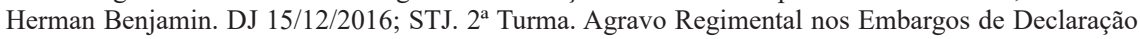
no Recurso Especial 1.381.341-MS, Rel. Min. Humberto Martins. DJ 25/05/2016.
}

23 STJ. $2^{\text {a }}$ Turma. Recurso Especial 948.921/SP, Rel. Min. Herman Benjamin. DJ 23/10/2007.

24 STJ. $2^{\text {a }}$ Turma. Agravo Regimental no Recurso Especial 1.494.681-MS, Rel. Min. Humberto Martins. DJ 03/11/2015. 
fato consumado levaria à perpetuação de um suposto "direito de poluir", 25 em absoluto desrespeito ao direito ao meio ambiente equilibrado como bem de uso comum do povo e que deve ser garantido para as presentes e futuras gerações. ${ }^{26}$

Debate sobre o litisconsórcio passivo nas ações civis públicas ambientais apresentam-se em diversas decisões, ${ }^{27}$ em que se partiu da premissa de que a responsabilidade do poluidor é objetiva e solidária, cabendo a todos aqueles que concorreram para a produção do dano ambiental, direta ou indiretamente, a obrigação solidária de reparação. ${ }^{28} \mathrm{O}$ entendimento de que o litisconsórcio é facultativo já se encontra pacificado no STJ, tendo sido, inclusive, considerado tese consolidada, nos seguintes termos: "Os responsáveis pela degradação ambiental são co-obrigados solidários, formando-se, em regra, nas ações civis públicas ou coletivas litisconsórcio facultativo". ${ }^{29}$

Nos acórdãos supracitados, embora o princípio do poluidorpagador não tenha sido assinalado expressamente, sua orientação pode ser identificada na fundamentação da responsabilidade solidária, pois quando há pluralidade de poluidores qualquer um deles pode ser responsabilizado sem que os outros tenham obrigatoriamente que integrar o polo passivo da ação, tendo em vista uma maior eficácia na reparação do dano ambiental e considerado o caráter reparatório do PPP.

25 Antes da edição da Súmula 613 do STJ, a questão já havia sido considerada como tese consolidada,
nos seguintes termos: "Não há direito adquirido a poluir ou degradar o meio ambiente, não existindo
permissão ao proprietário ou posseiro para a continuidade de práticas vedadas pelo legislador". (SU-
PERIOR TRIBUNAL DE JUSTIÇA. Jurisprudência em Teses. Direito Ambiental. N. 30. Brasília, 18
de Março de 2015). 26 STJ. 2a Turma. Recurso Especial 1.510.392-MS, Rel. Min. Herman Benjamin. Brasília. DJ 25/04/2017.

27 STJ. $2^{a}$ Turma. Recurso Especial 880.160-RJ, Rel. Min. Mauro Campbell. Brasília. DJ045/05/2010; STJ. $2^{\text {a }}$ Turma. Recurso Especial 884.150-MT, Rel. Min. Luiz Fux. Brasília. DJ 07/08/2008; STJ. 2 ${ }^{\mathrm{a}}$ Turma. Recurso Especial 843.978-SP, Rel. Min. Herman Benjamin. Brasília. DJ 09/03/2012; STJ. $2^{\text {a }}$ Turma. Recurso Especial 843.978-SP, Rel. Min. Herman Benjamin. Brasília. DJ 31/08/2009; STJ. $3^{\text {a }}$ Turma. Recurso Especial 1.363.107-DF, Rel. Min. Paulo de Tarso Sanseverino. Brasília. DJ 01/12/2015; STJ. 2a Turma. Recurso Especial 1.517.403-AL, Rel. Min. Herman Benjamin. Brasília. DJ 25/08/2015; STJ. $2^{\text {a }}$ Turma. Agravo Regimental no Agravo no Recurso Especial 548.908-DF, Rel. Min. Herman Benjamin. Brasília. DJ 5/05/2015; STJ. $4^{\text {a }}$ Turma. Agravo Regimental no Agravo no Recurso Especial 223.858-SP, Rel. Min. Luis Felipe Salomão. Brasília. DJ 09/09/2014; STJ. 2a Turma. Agravo Regimental no Recurso Especial 1.417.023-PR, Rel. Min. Humberto Martins. Brasília. DJ 25/08/2015; STJ. $2^{\text {a }}$ Turma. Agravo Interno no Agravo no Recurso Especial 839.492-SP, Rel. Min. Herman Benjamin. Brasília. DJ 15/12/2016.

28 A responsabilidade solidária e objetiva funda-se nos artigos $3^{\circ}$, IV e $14, \S 1^{\circ}$, da Lei 6938/81; artigo 225, 3ㅜ da Constituição Federal de 1988; e artigo 942, in fine, do Código Civil.

29 SUPERIOR TRIBUNAL DE JUSTIÇA. Jurisprudência em Teses. Direito Ambiental. N. 30. Brasília, 18 de Março de 2015. 
Os julgados do Recurso Especial $1.237 .893^{30}$ e dos Agravos Regimentais no Agravo em Recurso Especial 183.202-SP ${ }^{31}$ e 533.786$\mathrm{RJ}^{32}$ abordam a possibilidade de inversão do ônus da prova para que caiba àquele a quem se imputa dano ambiental demonstrar que de fato não o causou. Os principais fundamentos para esta inversão do ônus da prova são a aplicação do princípio da precaução (in dubio pro ambiente), em conjunto com interpretação sistemática dos artigos $6^{\circ}$, VIII, do Código de Defesa do Consumidor, cumulado com o artigo 21 da Lei da Ação Civil Pública. ${ }^{33}$

Por fim, cabe mencionar pioneiro acórdão do STJ sobre responsabilidade ambiental pós-consumo, que trata do descarte de garrafas de polietileno tereftalato (PET). A Quarta Turma do STJ decidiu, por maioria, negar provimento ao Recurso Especial 684.753-PR, ${ }^{34}$ interposto pela empresa responsável pelo envase de bebidas em embalagens do tipo PET. No julgado manteve-se a decisão de mérito do tribunal de origem, que responsabilizou objetivamente a empresa pela poluição do meio ambiente, determinando a adoção de providências com relação a destinação final ambientalmente adequada das embalagens plásticas de seus produtos. Evidencia-se a aplicação do princípio do poluidor-pagador tendo em vista o reconhecimento de ser inadequada e mesmo injurídica a transferência para a coletividade dos ônus relativos à coleta e ao tratamento dos resíduos oriundos do consumo do produto colocado no mercado pela empresa ré, o que expressa a determinação de internalização de externalidades ambientais negativas. Ao confirmar a sentença do Tribunal de Justiça do Paraná, o STJ reconheceu a responsabilidade ambiental pós-consumo, cuja tese tem como fio condutor o princípio do poluidor-pagador. ${ }^{35}$

Os acordãos integrantes do Grupo 1, todos relativos ao grande

30 STJ. $2^{\text {a }}$ Turma. Recurso Especial 650.728-SP, Rel. Min. Eliana Calmon. Brasília. DJ 24/09/2013.

31 STJ. $1^{\text {a }}$ Turma. Agravo Regimental no Agravo no Recurso Especial 183.202-SP, Rel. Min. Garcia Vieira. Brasília. DJ 09/06/1998.

32 STJ. $4^{a}$ Turma. Agravo Regimental no Agravo no Recurso Especial 533.786-RJ, Rel. Min. Antonio Carlos Ferreira. Brasília. DJ 22/09/2015.

33 Lei 8.078/1990; art. $6^{\circ}$. "São direitos básicos do consumidor: [...] VIII - a facilitação da defesa de seus direitos, inclusive com a inversão do ônus da prova, a seu favor, no processo civil, quando, a critério do juiz, for verossímil a alegação ou quando for ele hipossuficiente, segundo as regras ordinárias de experiências".

Lei 7.347/1985; art. 21. "À defesa dos direitos e interesses difusos, coletivos e individuais, no que for cabível, os dispositivos do Título III da lei que instituiu o Código de Defesa do Consumidor".

Sobre o assunto, cf. MOREIRA, 2015a, p. 1.209 e ss.

34 STJ. $4^{\text {a }}$ Turma. Recurso Especial 684.753-PR, Rel. Min. Antonio Carlos Ferreira. Brasília. DJ $18 / 08 / 2014$.

35 Sobre o tema responsabilidade ambiental pós-consumo, cf. MOREIRA, $2015 \mathrm{~b}$. 
tema da responsabilidade civil ambiental, e alguns de seus subtemas, expressam com clareza a orientação do princípio do poluidor-pagador, especialmente em sua vocação reparatória. Partindo-se da premissa de que o dano ambiental é uma das formas de expressão de externalidades ambientais negativas, não restam dúvidas sobre a identificação da responsabilidade civil como mecanismo que concretiza o PPP. Neste sentido, pode-se dizer que, nos casos analisados, a função reparatória do PPP foi aplicada adequadamente, tendo permitido a correta interpretação dos dispositivos legais pertinentes ao tema e garantido a imposição ao poluidor da responsabilidade pela reparação dos danos ambientais por ele causados, ainda que indiretamente, e, consequentemente, que este mesmo poluidor arque com os custos correlatos às medidas de reparação, sem coletivizá-las.

\subsection{Dano ambiental extrapatrimonial e teoria do risco integral: Grupo 2}

Dentre os acordãos pesquisados a partir da aplicação das palavras-chave, seguida da seleção qualitativa decorrente da análise das ementas, identificou-se um grupo de 41 decisões relativas a subtemas da responsabilidade civil ambiental que, logo se percebeu, tiveram seu aperfeiçoamento atribuído, em boa medida, à aplicação do princípio do poluidor-pagador. Trata-se dos julgados sobre dano ambiental extrapatrimonial individual e difuso e teoria do risco integral, apresentados em detalhe na tabela 2, anexa, e resumidamente na tabela a seguir.

\section{Julgados alocados no Grupo 2}

(dano ambiental extrapatrimonial e teoria do risco integral)

\begin{tabular}{|l|l|l|l|l|}
\hline GRUPO & ANOS & TURMAS & PALAVRAS-CHAVE & $\begin{array}{l}\text { NÚMERO } \\
\text { DE } \\
\text { ACORDÃOS }\end{array}$ \\
\hline $\begin{array}{l}\text { G2 Dano ambiental } \\
\text { extrapatrimonial } \\
\text { e teoria do risco } \\
\text { integral }\end{array}$ & 2002 a & $\begin{array}{l}1^{\mathrm{a}} \text { a } 4^{\mathrm{a}} \\
\text { Turmas do } \\
\text { STJ }\end{array}$ & $\begin{array}{l}\text { poluidor-pagador / poluidor } \\
\text { e pagador/ internalização e } \\
\text { ambiental / usuário e pagador/ } \\
\text { degradação e ambiente / } \\
\text { degradação e ambiental / } \\
\text { responsabilidade e civil e } \\
\text { ambiental / dano e ambiente / } \\
\text { dano e ambiental }\end{array}$ & 41 \\
\hline
\end{tabular}

Fonte: autoras 
Para que se dê adequada valoração dos danos ambientais, há que se considerar, além das perdas materiais, sua dimensão imaterial, extrapatrimonial. A identificação de que o conceito de meio ambiente engloba, essencialmente, valores não patrimoniais decorrentes de sua condição de direito humano fundamental, cuja integridade é essencial à sadia qualidade de vida, traduz-se na constatação da amplitude do conceito de dano ambiental, a abranger tanto a dimensão material quanto a extrapatrimonial. ${ }^{36}$ Os prejuízos imateriais decorrentes da degradação da qualidade ambiental podem ser individuais ou coletivos (lato sensu) (LEITE e MOREIRA, 2010, p. 117 e 118).

Sobre a teoria do risco aplicável à responsabilidade civil ambiental no Brasil, deve-se dizer que tem prevalecido doutrinária e jurisprudencialmente o entendimento de que a modalidade do risco integral é a que melhor se adequa à reparação de danos ambientais, não se admitindo as tradicionais excludentes de responsabilidade ${ }^{37}$ como caso fortuito ou de força maior. ${ }^{38}$

Quanto aos resultados jurisprudenciais alocados no Grupo 2, deve-se dizer, a título exemplificativo, que 17 deles correspondem a acidentes que ocasionaram significativos danos ao meio ambiente e comunidade de pescadores profissionais devido à contaminação hídrica por substâncias químicas (caso OLAPA). ${ }^{39}$ Os pedidos constantes das ações englobam a condenação dos réus por danos materiais e morais resultantes da contaminação. Dos julgados analisados, merece destaque o relativo ao Recurso Especial 1.114.398, ${ }^{40}$ julgado em 2009, pois foi a partir dele que o STJ reconheceu que os demais casos relacionados aos mesmos fatos e com idêntica questão de direito poderiam ser julgados como recursos repetitivos. ${ }^{41}$ Consequentemente, os 16 julgados restantes ${ }^{42}$ acompanham

36 Para maiores detalhes sobre o reconhecimento do dano ambiental extrapatrimonial, cf. LEITE e AYALA, 2011; STEIGLEDER, 2011; LEITE e MOREIRA, 2010; e MOREIRA, 2003.

37 Sobre a adoção da teoria do risco integral pela responsabilidade civil ambiental brasileira cf. MOREIRA, 2012, p. 234 e ss.

38 Art. 393, parágrafo único, do Código Civil: "O caso fortuito ou de força maior verifica-se no fato necessário, cujos efeitos não era possível evitar ou impedir".

39 Cf. Tema/repetitivo 707 disponível no índice de repetitivos sobre o tema Direito Ambiental no site do STJ.

40 STJ. 2 a Seção. Recurso Especial 1.114.398. Rel. Min. Sidnei Beneti. Brasília. DJ 16/02/2012.

41 Atualmente, o julgamento dos recursos especiais sob o rito dos repetitivos fundamentam-se nos artigos 1.036 a 1.041 do Código de Processo Civil (artigo 543-C do antigo Código de Processo Civil). 42 STJ. $3^{\text {a }}$ Turma. Agravo Regimental no Agravo em Recurso Especial 89.444-PR, Rel. Min. Paulo de

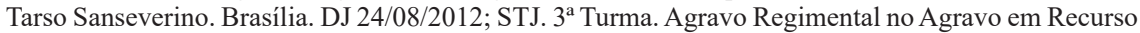
Especial 119.624-PR, Rel. Min. Ricardo Villas Bôas Cuevas. Brasília. DJ 13/12/2012; STJ. $4^{\text {a }}$ Turma. Agravo Regimental no Agravo em Recurso Especial 249.208-PR, Rel. Min. Marco Buzzi. Brasília. DJ 
as conclusões de direito deste caso, que, ante o argumento da defesa de que haveria no caso excludente de responsabilidade por culpa exclusiva de terceiro, entendeu ser "descabida a alegação da ocorrência de caso fortuito", vez que se aplica à responsabilidade civil ambiental a teoria do risco integral, ${ }^{43}$ para além de se tratar de responsabilidade objetiva (art. $225, \S 3^{\circ}$, da CF e do art. $14, \S 1^{\circ}$, da Lei $6.938 / 81$ ).

Dentre os 41 acordãos sobre dano ambiental extrapatrimonial e teoria do risco integral, 12 deles mencionam expressamente o princípio do poluidor-pagador, sempre de forma vinculada ao artigo 14 , parágrafo $1^{\circ}$, da Lei 6.938/81, ratificando a responsabilidade civil objetiva do poluidor. O PPP aparece, ainda, associado tanto à adoção da teoria do risco integral quanto ao reconhecimento e imposição da reparação do dano ambiental extrapatrimonial, sempre tendo em vista a reparação integral dos danos ambientais e, consequentemente, a internalização dos respectivos custos por quem a eles deu causa.

\subsection{Responsabilidade civil ambiental do estado por omissão: Grupo 3}

Dentre o total de 208 acórdãos selecionados para análise do seu inteiro teor, 19 tratam sobre responsabilidade civil ambiental do Estado por omissão, conforme indicação resumida a seguir e detalhada na tabela 3 , anexa.

07/02/2013; STJ. 4a Turma. Recurso Especial 1.346.430-PR, Rel. Min. Luis Felipe Salomão. Brasília. DJ 21/11/2012; STJ. 4a Turma. Agravo Regimental no Agravo em Recurso Especial 71.324-PR, Rel. Min. Antonio Carlos Ferreira. Brasília. DJ 05/03/2013; STJ. $4^{\text {a }}$ Turma. Agravo Regimental no Agravo em Recurso Especial 92.652-PR, Rel. Min. Antonio Carlos Ferreira. Brasília. DJ 04/03/2013; STJ.

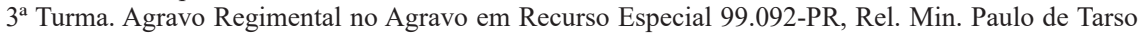
Sanseverino. Brasília. DJ 01/04/2013; STJ. $3^{\text {a }}$ Turma. Agravo Regimental no Agravo em Recurso Especial 238.427-PR, Rel. Min. Ricardo Villas Bôas Cuevas. Brasília. DJ 09/08/2013; STJ. $3^{\text {a }}$ Turma. Agravo Regimental no Agravo em Recurso Especial 254.149-PR, Rel. Min. Sidnei Beneti. Brasília. DJ 01/03/2013; STJ. 4a Turma. Agravo Regimental no Agravo em Recurso Especial 258.263-PR, Rel.

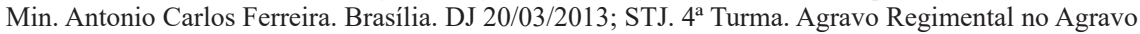
em Recurso Especial 273.058-PR, Rel. Min. Antonio Carlos Ferreira. Brasília. DJ 27/04/2013; STJ. $4^{\mathrm{a}}$ Turma. Agravo Regimental no Agravo em Recurso Especial 281.177-PR, Rel. Min. Raul Araújo. Brasília. DJ 08/05/2013; STJ. 4ª Turma. Embargos de Declaração no Recurso Especial 1.346.430-PR, Rel. Min. Luis Felipe Salomão. Brasília. DJ 14/02/2013; STJ. 2a Seção. Recurso Especial 1.354.536SE, Rel. Min. Luis Felipe Salomão. Brasília. DJ 05/05/2014; STJ. 4 ${ }^{\mathrm{a}}$ Turma. Agravo Regimental no Recurso Especial 117.202-PR, Rel. Min. Antonio Carlos Ferreira. Brasília. DJ 30/11/2015; STJ. 4 ${ }^{\text {a }}$ Turma. Agravo Regimental no Recurso Especial 232.494-PR, Rel. Min. Marco Buzzi. Brasília. DJ $26 / 10 / 2015$.

43 STJ. $2^{\text {a }}$ Seção. Recurso Especial 1.114.398. Rel. Min. Sidnei Beneti. Brasília. DJ 16/02/2012. p. $13-15$. 


\section{Julgados alocados no Grupo 3 (responsabilidade civil ambiental do estado por omissão)}

\begin{tabular}{|c|c|c|c|c|}
\hline GRUPO & ANOS & TURMAS & PALAVRAS-CHAVE & $\begin{array}{l}\text { NÚMERO DE } \\
\text { ACÓRDÃOS }\end{array}$ \\
\hline $\begin{array}{l}\text { G3 } \\
\text { Responsabilidade } \\
\text { civil ambiental do } \\
\text { Estado por omissão }\end{array}$ & $\begin{array}{l}2000 \mathrm{a} \\
2017\end{array}$ & $\begin{array}{l}1^{\mathrm{a}} \text { e } 2^{\mathrm{a}} \\
\text { Turmas do } \\
\text { STJ }\end{array}$ & $\begin{array}{l}\text { custos e ambiente / } \\
\text { custos e ambientais / } \\
\text { poluidor-pagador / } \\
\text { externalidade e ambiental } \\
\text { e negativa / externalidade/ } \\
\text { internalização e ambiente / } \\
\text { internalização e ambiental } \\
\text { / degradação e ambiente } \\
\text { / degradação e ambiental } \\
\text { / responsabilidade e } \\
\text { civil e ambiental / dano } \\
\text { e ambiente / dano e } \\
\text { ambiental }\end{array}$ & 19 \\
\hline
\end{tabular}

Fonte: autoras

Se não há dúvida sobre o caráter objetivo da responsabilidade civil ambiental do Estado por atos comissivos - seja em razão dos artigos 14, parágrafo $1^{\circ}$, e $3^{\circ}, I V$, da Lei 6.938/1981, seja por conta do artigo 37, parágrafo $6^{\circ}$, da Constituição Federal - o mesmo não acontece quando omissão estatal dá causa ou contribui para a causação de dano ao meio ambiente. Nesta hipótese, argumenta-se tanto no sentido de que a responsabilidade civil ambiental do Estado por omissão seria, em regra, subjetiva (tese que tem predominado sobre a responsabilidade civil do Estado em geral), ${ }^{44}$ quanto em defesa de tese de que prevalece a previsão da responsabilidade constante em lei específica (que, no caso de reparação por danos ambientais, dispõe, expressamente, que também por omissão ou na condição de poluidor indireto - o Estado responde objetivamente). ${ }^{45}$

44 O Estado só se responsabilizaria quando demonstrado que sua omissão se deu por culpa, descumprindo seu dever legal de evitar o dano. Em defesa deste entendimento, cf. CARVALHO FILHO, 2012, p. 188; DIPIETRO, 2012, p. 709; MELLO, 2014, p. 1.050.

45 Lei 6.938/1981, art. $3^{\circ}$ : "Para os fins previstos nesta Lei, entende-se por: [...] IV - poluidor, a pessoa física ou jurídica, de direito público ou privado, responsável, direta ou indiretamente, por atividade causadora de degradação ambiental". Lei 6.938/1981, art. 14. § $1^{\circ}$. "“...] é o poluidor obrigado, independentemente da existência de culpa, a indenizar ou reparar os danos causados ao meio ambiente e a terceiros, afetados por sua atividade. [...]". 
Este tema tem sido objeto de debate no Superior Tribunal de Justiça e apresenta interessante discussão relativa ao princípio do poluidorpagador, cuja orientação tem sido utilizada com o objetivo de tentar temperar a responsabilização do Estado (ao final, da própria coletividade) na condição de poluidor indireto, de modo a evitar que este seja chamado a reparar dano ambiental - e, consequentemente, arcar com os respectivos custos - antes de se buscar que o poluidor direto empreenda esforços e aloque recursos para este fim. Veja-se como os acórdãos arrolados no Grupo 3 demonstram a evolução jurisprudencial do tema.

Dentre os julgados encontrados, merecem destaque os relativos aos Recursos Especiais 647.493-SC, ${ }^{46}$ e 1.071.741-SP, ${ }^{47}$ que trataram de forma diversa da responsabilização civil ambiental do Estado por omissão.

No primeiro caso, o MPF ajuizou ação civil pública em face de diversas empresas mineradoras e da União Federal em razão de danos ambientais decorrentes de atividade minerária. Embora a União tenha siso condenada solidariamente com as empresas diretamente causadoras dos danos ambientais com base na sua responsabilidade subjetiva (com culpa), deve-se destacar que seu argumento de defesa foi no sentido de ver reconhecida alegada ilegitimidade passiva, tendo utilizado para fundamentar a tese a própria orientação do princípio do poluidor-pagador. Explica-se. A União Federal argumentou que, ao ser responsabilizada objetivamente-por danos com os quais não contribuiu diretamente, acabaria por submeter a coletividade a prejuízo em dobro: o primeiro identificado no dano ambiental propriamente dito - e suas consequências diretas em perda de qualidade de vida para a população - e o outro representado pelo aporte de recursos públicos para fazer frente à degradação ambiental o que significaria verdadeira socialização das perdas e privatização dos ganhos (vez que os poluidores diretos acabariam por não arcar com os ônus financeiros da reparação), em desrespeito ao PPP.

A segunda Turma do STJ condenou a União com base na sua omissão - culposa - em descumprimento de dever legal de fiscalizar atividades extrativas de carvão mineral (poluidor indireto), considerando-a solidariamente responsável com as sociedades mineradoras (poluidores diretos) e frisando, entretanto, a necessidade de que, uma vez instado a

46 STJ. $2^{\text {a }}$ Turma. Recurso Especial 647.493-SC. Min. Rel. João Otávio de Noronha. Brasília. DJ 22/05/2007.

47 STJ. $2^{\text {a }}$ Turma. Recurso Especial 1.071.741-SP. Min. Rel. Herman Benjamin. Brasília. DJ $16 / 12 / 2010$ 
pagar, o ente público teria, não somente o direito, mas o dever de procurar o ressarcimento total das quantias despendidas ("dever de regresso"). Este acordão é importante porque deu início à discussão sobre como a orientação do princípio do poluidor-pagador (para evitar socialização de ônus e privatização de bônus) deve ser considerada nas ações civis públicas ambientais em que figuram como réus, além do poluidor direto, o Estado, como poluidor indireto.

Neste sentido, deve-se mencionar o julgado relativo ao REsp 1.071.741-SP, ${ }^{48}$ que trata de caso de ocupação ilegal por particular no Parque Estadual de Jacupiranga, em São Paulo, decorrente de omissão do Poder Público - no caso, o Estado de São Paulo - do seu dever de fiscalização ambiental de unidade de conservação sob sua administração, diante de situação de turbação e esbulho do bem público. Parte-se da premissa de que, segundo a Constituição Federal (arts. 225, 23, VI e VII, e 170, VI) e a Lei da Política Nacional do Meio Ambiente (Lei 6.938/81 arts. $2^{\circ}$, I e V, e $6^{\circ}$ ), a atuação do Poder Público em defesa do meio ambiente é “indisponível, irrenunciável e imprescritível". ${ }^{49}$

No referido julgado, o relator, Ministro Herman Benjamin, inovou ao decidir que a execução do Estado como poluidor indireto - ainda que sua responsabilidade por omissão seja objetiva, solidária e ilimitada deve se dar de modo subsidiário à do devedor principal (poluidor direto), de modo que não haja, de acordo com o princípio do poluidor-pagador, a socialização dos ônus e a privatização dos bônus. Desde modo, evitase que, na prática, o poluidor direto acabe não arcando com as despesas relativas à reparação dos danos ambientais, enquanto a coletividade, além de sofrer as consequências de degradação ambiental, suporta os custos da sua reparação via aporte de recursos públicos (pelo Estado poluidor indireto) para este fim.

Deve-se destacar que se mantém o reconhecimento da responsabilidade civil do Estado, sem, no entanto, onerar a coletividade de modo equivalente a que se faz com o poluidor direto. Primeiramente, os poluidores diretos são chamados a reparar o dano, ficando o Estado na posição de garante, de reserva (ainda que na condição de devedor solidário), assegurada ao meio ambiente a solução jurídica mais adequada 48 STJ. $2^{\text {a }}$ Turma. Recurso Especial 1.071.741-SP. Min. Rel. Herman Benjamin. Brasília. DJ $16 / 12 / 2010$.

49 STJ. $2^{\text {a }}$ Turma. Recurso Especial 1.071.741-SP. Rel. Min. Herman Benjamin. Brasília. DJ 16/12/2010. p. 7 . 
e evitando-se a socialização dos ônus e a privatização dos bônus, ${ }^{50} \mathrm{em}$ consonância com a orientação do PPP. ${ }^{51}$

\title{
2.4 Possibilidade de cumulação de obrigações de fazer e pagar: Grupo 4
}

\author{
Neste Grupo 4, foram arrolados 39 julgados do STJ que tratam \\ da possibilidade do pedido de cumulação das obrigações de fazer e pagar \\ do poluidor, conforme resumidamente identificado a seguir e, em detalhe, \\ na tabela 4 , anexa.
}

\begin{abstract}
50 Nos termos de trecho da ementa do acórdão em referência:
“13. A Administração é solidária, objetiva e ilimitadamente responsável, nos termos da Lei 6.938/1981, por danos urbanístico-ambientais decorrentes da omissão do seu dever de controlar e fiscalizar, na medida em que contribua, direta ou indiretamente, tanto para a degradação ambiental em si mesma, como para o seu agravamento, consolidação ou perpetuação, tudo sem prejuízo da adoção, contra o agente público relapso ou desidioso, de medidas disciplinares, penais, civis e no campo da improbidade administrativa.

14. No caso de omissão de dever de controle e fiscalização, a responsabilidade ambiental solidária da Administração é de execução subsidiária (ou com ordem de preferência).

15. A responsabilidade solidária e de execução subsidiária significa que o Estado integra o título executivo sob a condição de, como devedor-reserva, só ser convocado a quitar a dívida se o degradador original, direto ou material (= devedor principal) não o fizer, seja por total ou parcial exaurimento patrimonial ou insolvência, seja por impossibilidade ou incapacidade, inclusive técnica, de cumprimento da prestação judicialmente imposta, assegurado, sempre, o direito de regresso (art. 934 do Código Civil), com a desconsideração da personalidade jurídica (art. 50 do Código Civil).

16. Ao acautelar a plena solvabilidade financeira e técnica do crédito ambiental, não se insere entre as aspirações da responsabilidade solidária e de execução subsidiária do Estado - sob pena de onerar duplamente a sociedade, romper a equação do princípio poluidor-pagador e inviabilizar a internalização das externalidades ambientais negativas - substituir, mitigar, postergar ou dificultar o dever, a cargo do degradador material ou principal, de recuperação integral do meio ambiente afetado e de indenização pelos prejuízos causados". (STJ. 2a Turma. Recurso Especial 1.071.741-SP. Min. Rel. Herman Benjamin. Brasília. DJ 16/12/2010).

51 Antes da publicação do julgado paradigmático em comento, chama-se a atenção para dois julgados: os dos Agravos Regimentais no Agravo de Instrumento 822.764-MG (STJ. $1^{\text {a }}$ Turma. Agravo Regimental no Agravo de Instrumento 822.764-MG. Min. Rel. José Delgado. Brasília. DJ 05/06/2007) e 973.577-SP (STJ. 2 ${ }^{\text {a }}$ Turma. Agravo Regimental no Agravo de Instrumento 973-577-SP. Min. Rel. Mauro Campbell. Brasília. DJ 16/09/2008). Nos dois casos, o Estado foi considerado como responsável solidário do poluidor direto devido a condutas omissivas quanto ao dever de fiscalizar. Contudo, não se estabeleceu a subsidiariedade em relação ao cumprimento da obrigação de reparar os danos. Tal fato não condiz com a melhor solução para o caso tendo em vista a aplicação do PPP, visto que responsabilizar de maneira igual agentes públicos e privados responsáveis, respectivamente, de modo indireto e direto pelo dano ambiental, acaba por sobrecarregar duplamente a coletividade.
\end{abstract}




\section{Julgados alocados no Grupo 4} possibilidade de cumulação de obrigações de fazer e pagar)

\begin{tabular}{|c|c|c|c|c|}
\hline GRUPO & ANOS & TURMAS & PALAVRAS-CHAVE & $\begin{array}{l}\text { NÚMERO DE } \\
\text { ACÓRDÃOS }\end{array}$ \\
\hline $\begin{array}{l}\text { G4 } \\
\text { Possibilidade } \\
\text { de cumulação } \\
\text { de obrigação de } \\
\text { fazer e de pagar }\end{array}$ & $\begin{array}{l}2001 \\
\text { a } 2018\end{array}$ & $\begin{array}{l}1^{\mathrm{a}} \text { a } 3^{\mathrm{a}} \\
\text { Turmas do } \\
\text { STJ. }\end{array}$ & $\begin{array}{l}\text { poluidor-pagador / } \\
\text { internalização e ambiental / } \\
\text { usuário e pagador / poluidor } \\
\text { e pagador / degradação e } \\
\text { ambiente / degradação e } \\
\text { ambiental / responsabilidade } \\
\text { e civil e ambiental / dano e } \\
\text { ambiente / dano e ambiental/ } \\
\text { usuário e pagador/ usuário- } \\
\text { pagador }\end{array}$ & 39 \\
\hline
\end{tabular}

Fonte: autoras

Por se tratarem de decisões que abordam de maneira semelhante a possibilidade de cumulação das obrigações de fazer e pagar na mesma ação civil pública (ainda que em algumas situações tenha se considerado não ser o caso de condenação à obrigação de indenizar), ${ }^{52}$ os acórdãos serão analisados em conjunto.

Das 39 decisões selecionadas, 36 são em ações civis públicas. ${ }^{53}$ Nos termos expressos da Lei 7.347/1985, a ação civil pública poderá ter

52 Dos 39 acórdãos integrantes do Grupo 4, 11 negaram o pedido de indenização, embora tenham reconhecido que existe a possibilidade de cumulação dos pedidos de fazer, não fazer e indenizar. (STJ. $2^{\mathrm{a}}$ Turma. Recurso Especial 1.165.281-MG, Rel. Min. Eliana Calmon. Brasília. DJ 17/05/2010; STJ. $2^{\mathrm{a}}$ Turma. Recurso Especial 1.248.214-MG, Rel. Min. Herman Benjamin. Brasília. DJ 18/08/2011; STJ. $2^{a}$ Turma. Recurso Especial 1.382.999-SC, Rel. Min. Humberto Martins. Brasília. DJ 18/09/2014; STJ.

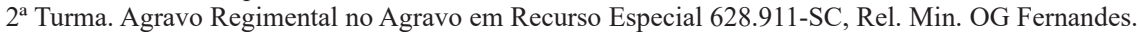
Brasília. DJ 01/07/2015; STJ. 2a Turma. Recurso Especial 1.486.195-SC, Rel. Min. Humberto Martins. Brasília. DJ 11/03/2016; STJ. 2a Turma. Agravo Interno no Agravo em Recurso Especial 584.736RJ, Rel. Min. Assusete Magalhães. Brasília. DJ 28/09/2016; STJ. $2^{\text {a }}$ Turma. Agravo Regimental no Recurso Especial 1.154.986-MG, Rel. Min. Diva Malerbi. Brasília. DJ 12/02/2016; STJ. $2^{\text {a }}$ Turma. Agravo Regimental no Agravo 1.365.693-MG, Rel. Min. Napoleão Nunes Maia Filho. Brasília. DJ 10/10/2016; STJ. 2a Turma. Agravo Interno no Recurso Especial 1.532.643-SC, Rel. Min. Assusete Magalhães. Brasília. DJ 23/10/2017; STJ. 2a Turma. Agravo Interno no Recurso Especial 1.577.736SC, Rel. Min. Og Fernandes. Brasília. DJ 09/08/2017.) Nestes julgados, foram consideradas situações em que não restaram demonstrados outros prejuízos, além dos que já foram objeto de condenação em obrigação de reparação in natura, não tendo o STJ determinado o pagamento de indenização.

53 A ação civil pública é o mais importante instrumento processual utilizado para a defesa dos interesses difusos, dentre os quais se encontra o direito ao meio ambiente ecologicamente equilibrado. Segundo a Constituição Federal, em seu artigo 129, II e III, a propositura da ação civil pública é uma das funções do Ministério Público, sem que este seja, contudo, o único ente legitimado à sua propositura (cf. Lei 7.347/1985). 
por objeto "a condenação em dinheiro ou o cumprimento de obrigação de fazer ou não fazer" (art. $3^{\circ}$ ). Tendo em vista a redação do dispositivo legal, discutiu-se, nos acórdãos alocados no Grupo 4, a possibilidade de cumulação da obrigação de fazer (reparação em si) e de pagar (indenização) em ações civis públicas ambientais, a partir de uma interpretação não literal do dispositivo citado, defendendo-se que a conjunção "ou" deve ser entendida como "e", de modo a garantir a reparação integral do dano ambiental. ${ }^{54}$

As decisões aqui analisadas são ricas em fundamentações jurídicas acerca do princípio do poluidor-pagador e da reparação integral do dano ambiental. O Ministro Herman Benjamin, relator de 5 dos julgados, foi incisivo em suas colocações acerca da necessidade de o poluidor arcar com o valor a título de indenização, além da obrigação de recuperar a o dano.

Importante ressaltar, ainda, que o dever de reparar (fazer) e o de indenizar (pagar) não tem caráter sancionatório, sendo parte do conjunto de medidas ressarcitórias de natureza civil, sempre que a restauração in natura não seja suficiente à recomposição integral do dano. ${ }^{55}$ Deve-se garantir a recomposição integral do dano ambiental, internalizando-se suficientemente as externalidades ambientais negativas, o que não ocorre apenas com a restauração in natura, mas depende do reconhecimento de que o prejuízo em qualidade de vida sofrido pela coletividade no período

\footnotetext{
54 A presença do "ou" no artigo não pode ser entendida como alternativa excludente, mas sim "tem valor aditivo, uma vez que segundo o princípio in dubio pro natura, a legislação concernente aos direitos da coletividade deve ser sempre interpretada da forma que lhes for mais favorável, de forma a viabilizar a prestação jurisdicional necessária”. (STJ. 2 ${ }^{\mathrm{a}}$ Turma. Recurso Especial 1.165.284-MG, Rel. Min. Herman Benjamin. Brasília. DJ 12/04/2012. p. 2). No mesmo sentido: “a conjunção 'ou' contida na citada norma (assim como nos arts. $4^{\circ}$, VII, e $14, \S 1^{\circ}$, da Lei 6.938/1981) opera com valor aditivo, não introduz alternativa excludente. Vedar a cumulação desses remédios limitaria, de forma indesejada, a Ação Civil Pública, instrumento de persecução da responsabilidade civil de danos causados ao meio ambiente, por exemplo inviabilizando a condenação em dano moral coletivo". (STJ. $2^{\mathrm{a}}$ Turma. Recurso Especial 1.198.727-MG, Rel. Min. Herman Benjamin. Brasília. DJ 14/08/2012).

55 Neste sentido, lê-se em trecho do acordão relativo ao Recurso Especial 1.180.078-MG:

"3. A restauração in natura nem sempre é suficiente para reverter ou recompor integralmente, no terreno da responsabilidade civil, o dano ambiental causado, daí não exaurir o universo dos deveres associados aos princípios do poluidor-pagador e da reparação in integrum.

4. A reparação ambiental deve ser feita da forma mais completa possível, de modo que a condenação a recuperar a área lesionada não exclui o dever de indenizar, sobretudo pelo dano que permanece entre a sua ocorrência e o pleno restabelecimento do meio ambiente afetado ( $=$ dano interino ou intermediário), bem como pelo dano moral coletivo e pelo dano residual (= degradação ambiental que subsiste, não obstante todos os esforços de restauração).

5. A cumulação de obrigação de fazer, não fazer e pagar não configura bis in idem, porquanto a indenização não é para o dano especificamente já reparado, mas para os seus efeitos remanescentes, reflexos ou transitórios, com destaque para a privação temporária da fruição do bem de uso comum do povo, até sua efetiva e completa recomposição, assim como o retorno ao patrimônio público dos benefícios econômicos ilegalmente auferidos." (STJ. $2^{\mathrm{a}}$ Turma. Recurso Especial 1.180.078-MG, Rel. Min. Herman Benjamin. Brasília. DJ 02/12/2010).
} 
em que perdurar a degradação ambiental deve ser considerado como parte do dano e, logo, devidamente indenizado. ${ }^{56}$

Por todos esses aspectos, constata-se que a jurisprudência brasileira, no que tange à interpretação e aplicação do princípio do poluidor-pagador nas decisões aqui mencionadas, vem agindo de forma acertada ao garantir ao meio ambiente proteção integral diante do dano causado, determinando a internalização dos custos de reparação por meio da condenação em obrigação de reparação do dano e, conforme o caso, também de indenizar.

\subsection{Compensação ambiental do Sistema Nacional de Unidades de Conservação (SNUC): Grupo 5}

A busca a partir das palavras-chave escolhidas resultou na identificação de apenas 2 julgados (1 do STF e 1 do STJ) que tratam da compensação ambiental do Sistema Nacional de Unidades de Conservação (SNUC), ${ }^{57}$ conforme apresentado em detalhe na tabela 5, anexa, e de modo resumido a seguir.

\footnotetext{
56 A este respeito, observa Machado que "não é apenas a agressão à natureza que deve ser objeto de reparação, mas a privação, imposta à coletividade, do equilíbrio ecológico, do bem-estar e da qualidade de vida que aquele recurso ambiental proporciona, em conjunto com os demais. Desse modo, a reparação do dano ambiental deve compreender, também, o período em que a coletividade ficará privada daquele bem e dos efeitos benéficos que ele produzia, por si mesmo e em decorrência de sua interação (art. $3^{\circ}$, I, da Lei 6.938/81). Se a recomposição integral do equilíbrio ecológico, com a reposição da situação anterior ao dano, depender, pelas leis da natureza, de lapso de tempo prolongado, a coletividade tem direito subjetivo a ser indenizada pelo período que mediar entre a ocorrência do dano e a integral reposição da situação anterior". (MACHADO, 2009. p. 365).

57 As Unidades de Conservação são uma espécie de espaços territoriais especialmente protegidos, nos termos do artigo 225 , parágrafo $1^{\circ}$, III, da Constituição Federal e, conforme definição específica do artigo $2^{\circ}$, I, da Lei 9.985/2000, são o "espaço territorial e seus recursos ambientais, incluindo as águas jurisdicionais, com características naturais relevantes, legalmente instituído pelo Poder Público, com objetivos de conservação e limites definidos, sob regime especial de administração, ao qual se aplicam garantias adequadas de proteção".
} 


\section{Julgados alocados no Grupo 5 (Compensação ambiental do SNUC)}

\begin{tabular}{|c|c|c|c|c|}
\hline GRUPO & ANOS & TURMAS & PALAVRAS-CHAVE & $\begin{array}{l}\text { NÚMERO DE } \\
\text { ACÓRDÃOS }\end{array}$ \\
\hline G5 & 2008 a 2011 & Tribunal & custos e ambiente / custos & 2 \\
\hline Compensação & & Pleno do STF & e ambientais / degradação & \\
\hline ambiental & & e $2^{\mathrm{a}}$ Turma do & e ambiente / degradação e & \\
\hline do Sistema & & STJ & ambiental / dano e ambiente/ & \\
\hline Nacional de & & & poluidor e pagador / usuário- & \\
\hline Unidades de & & & pagador / usuário e pagador / & \\
\hline Conservação & & & ambiental/ dano e ambiente/ & \\
\hline (SNUC) & & & dano e ambiental & \\
\hline
\end{tabular}

Fonte: autoras

A compensação ambiental de que tratam os julgados em referência é aquela prevista na Lei 9.985/2000 (Lei do SNUC), exigida no âmbito do licenciamento ambiental de empreendimentos causadores de significativo impacto ambiental ${ }^{58}$ e destinada, nos termos expressos da lei, ao apoio à implantação e manutenção de unidades de conservação. ${ }^{59}$ A base para a definição do valor a ser aportado a título de compensação ambiental é o Estudo Prévio de Impacto Ambiental (EIA) e seu respectivo

58 Cf. art. $225, \S 1^{\circ}, \mathrm{IV}, \mathrm{CF} / 88$ sobre exigência de Estudo Prévio de Impacto Ambiental para o licenciamento de empreendimentos potencialmente causadores de significativa degradação do meio ambiente.

59 Redação atual do artigo 36 da Lei 9.985/2000:

"Art. 36. Nos casos de licenciamento ambiental de empreendimentos de significativo impacto ambiental, assim considerado pelo órgão ambiental competente, com fundamento em estudo de impacto ambiental e respectivo relatório - EIA/RIMA, o empreendedor é obrigado a apoiar a implantação e manutenção de unidade de conservação do Grupo de Proteção Integral, de acordo com o disposto neste artigo e no regulamento desta Lei.

$\S 1^{\circ} \mathrm{O}$ montante de recursos a ser destinado pelo empreendedor para esta finalidade [não pode ser inferior a meio por eento dos eustos totais previstos para a implantação do empreendimento], sendo o percentual fixado pelo órgão ambiental licenciador, de acordo com o grau de impacto ambiental causado pelo empreendimento.

$\S 2^{\circ}$ Ao órgão ambiental licenciador compete definir as unidades de conservação a serem beneficiadas, considerando as propostas apresentadas no EIA/RIMA e ouvido o empreendedor, podendo inclusive ser contemplada a criação de novas unidades de conservação.

$\S 3^{\circ}$ Quando o empreendimento afetar unidade de conservação específica ou sua zona de amortecimento, o licenciamento a que se refere o caput deste artigo só poderá ser concedido mediante autorização do órgão responsável por sua administração, e a unidade afetada, mesmo que não pertencente ao Grupo de Proteção Integral, deverá ser uma das beneficiárias da compensação definida neste artigo".

O trecho do parágrafo $1^{\circ}$, acima tachado, "não pode ser inferior a meio por cento dos custos totais previstos para a implantação do empreendimento" foi declarado inconstitucional no julgamento da ADI 3378. (STF. Tribunal Pleno. ADI 3.378-6 Distrito Federal. Rel. Min. Carlos Britto. Brasília. DJU: 20/06/08). 
Relatório de Impacto Ambiental (RIMA), tendo como objetivo a garantia da efetiva compensação de impacto significativo - não evitável, embora tolerável e, por isso, autorizado - que efetivamente decorrerá da instalação e funcionamento da atividade licenciada. ${ }^{60}$

O primeiro dos dois julgados arrolados no Grupo 5 é o acórdão relativo à ADI $3378,{ }^{61}$ em que se analisa a correlação entre o instituto da compensação ambiental e a orientação do PPP. Tomando por base o ideal de internalização de externalidades ambientais negativas, o STF afirmou ser a compensação ambiental prevista na Lei do SNUC "mecanismo de assunção partilhada de responsabilidade social pelos custos ambientais derivados da atividade econômica", não havendo "outro meio eficaz para atingir essa finalidade constitucional [de proteção do meio ambiente para as presentes e futuras gerações] senão impondo ao empreendedor o dever de arcar, ao menos em parte, com os custos de prevenção, controle e reparação dos impactos negativos ao meio ambiente". ${ }^{62}$ A importância desta internalização diretamente pelo empreendedor está no fato de que é este "o beneficiário direto dos bônus a serem proporcionados pelo empreendimento, de forma que o custo ambiental esteja incorporado em seu custo de produção, não impingindo a conta das externalidades negativas do empreendimento apenas à população, titular do direito difuso ao bem essencial impactado: o meio ambiente (art. 225, caput, $\mathrm{CF} / 88$ )" (MOREIRA e NEVIANI, 2017, p. 186).

Já no Recurso Especial 896.863-DF, ${ }^{63}$ o que se questionava era a possibilidade de cumulação da indenização por danos ambientais com a compensação ambiental. Tal impossibilidade é afastada, uma vez que a primeira diz respeito ao pagamento por resultado ilícito de atividade (o dano ambiental), enquanto a segunda nada mais é que pagamento destinado a compensar impacto ambiental previsto e autorizado, porque considerado tolerável, pelos órgãos ambientais.

Os dois julgados fazem menção expressa e pretendem concretizar a orientação do princípio do poluidor-pagador, principalmente no que diz respeito ao seu caráter reparatório, pois identificam na compensação ambiental mecanismo de incorporação no processo produtivo dos custos ambientais externos a atividades causadoras de significativa degradação ambiental, evitando-se a socialização de perdas e a privatização de ganhos. 60 Sobre o assunto, cf. MOREIRA e NEVIANI, 2017.

61 STF. Tribunal Pleno. ADI 3.378-6 Distrito Federal. Rel. Min. Carlos Britto. Brasília. DJU: 20/06/08. 62 STF. Tribunal Pleno. ADI 3.378-6 Distrito Federal. Rel. Min. Carlos Britto. Brasília. DJU: 20/06/08. 63 STJ. $2^{\text {a }}$ Turma. Recurso Especial 896.863-DF, Rel. Min. Castro Meira. Brasília. DJ 02/06/2011. 


\subsection{Responsabilidade administrativa ambiental: Grupo 6}

Conforme apresentado a seguir e na tabela 6, anexa, 9 acórdãos foram classificados como sendo relativos ao tema da responsabilidade ambiental administrativa, sendo possível observar que apenas $1^{64}$ faz menção expressa ao princípio do poluidor-pagador. No entanto, tais acórdãos foram escolhidos e analisados porque se considerou que o PPP aparece de forma implícita e seu conceito (amplo) foi utilizado - nem sempre de forma acurada - como um dos fundamentos para as decisões aqui encontradas.

\section{Julgados alocados no Grupo 6 (responsabilidade administrativa ambiental)}

\begin{tabular}{|l|l|l|l|l|}
\hline GRUPO & ANOS & TURMAS & PALAVRAS-CHAVE & $\begin{array}{l}\text { NÚMERO DE } \\
\text { ACÓRDÃOS }\end{array}$ \\
\hline $\begin{array}{l}\text { G 6 } \\
\text { Responsabilidade } \\
\text { administrativa } \\
\text { ambiental }\end{array}$ & 2002 a 2017 & $\begin{array}{l}1^{\mathrm{a}} \mathrm{e} 2^{\mathrm{a}} \\
\text { Turmas do } \\
\text { STJ }\end{array}$ & $\begin{array}{l}\text { Externalidade / } \\
\text { externalidade e ambiental } \\
\text { e negativa / degradação e } \\
\text { ambiente / degradação e } \\
\text { ambiental / responsabilidade } \\
\text { e civil e ambiental / dano e } \\
\text { ambiente/ dano e ambiental/ } \\
\text { poluidor-pagador/ poluidor } \\
\text { e pagador }\end{array}$ & 9 \\
\hline
\end{tabular}

Fonte: autoras

Em linhas gerais, os julgados discutem o caráter objetivo ou subjetivo da responsabilidade administrativa ambiental, ${ }^{65}$ oscilando o STJ em seu entendimento a respeito. No julgamento do Recurso Especial 1.318.051-RJ, ${ }^{66}$ por exemplo, partiu-se da premissa de que a responsabilidade ambiental administrativa, assim como a civil, é objetiva,

64 STJ. $2^{\text {a }}$ Turma. Recurso Especial 1.401.500-PR, Rel. Min. Herman Benjamin. Brasília. DJ $16 / 08 / 2016$

65 Sobre as principais características da responsabilidade ambiental administrativa, cf. MOREIRA e 2015.

66 STJ. $1^{\text {a }}$ Turma. Recurso Especial 1.318.051-RJ, Rel. Min. Benedito Gonçalves. Brasília. DJ $17 / 03 / 2015$. 
enquanto em outros acórdãos afirmou-se depender de culpa a aplicação de penalidades por infrações administrativas ambientais. ${ }^{67}$

$\mathrm{O}$ acordão relativo ao REsp $1.401 .500-\mathrm{PR},{ }^{68} \mathrm{o}$ único dentre os casos arrolados ao Grupo 6 em que se encontrou referência expressa ao princípio do poluidor-pagador, trata de ação anulatória de débito em que o Tribunal de Justiça do Estado do Paraná ratificou multa de R 12 milhões aplicada à empresa Hexion Química, que, apesar de proprietária da carga transportada, não teve participação direta no acidente ambiental. Neste caso, a empresa foi responsabilizada administrativamente por danos ambientais ocorridos em decorrência da explosão do navio Vicuña, na baía de Paranaguá, em novembro de 2014. No entanto, a $2^{\text {a }}$ Turma do STJ determinou o retorno dos autos "à origem para que aborde a questão a partir da responsabilização administrativa subjetiva e analise se está presente a culpa da recorrente na ocorrência do dano ambiental debatido nos presentes autos" ${ }^{69}$ Importa dizer que a referência expressa ao PPP neste julgado deve-se tão somente à consideração realizada pelo relator Ministro Herman Benjamin, ao comparar as características da responsabilidade administrativa e civil ambiental. ${ }^{70}$

Os demais casos aqui analisados não fizeram referência expressa ao PPP e tratavam de imposição de sanções administrativas em razão de infrações ambientais, sendo necessário salientar que essas penalidades não se configuram como externalidades ambientais negativas a serem internalizadas. Diz-se isso porque, diferentemente dos custos de reparação de danos ambientais, o valor relativo a multas não representa custo

67 STJ. $1^{\text {a }}$ Turma. Agravo Regimental no Agravo em Recurso Especial 62.584-RJ, Rel. Min. Regina Helena Costa. Brasília. DJ 18/06/2015; STJ. 2 ${ }^{\mathrm{a}}$ Turma. Recurso Especial 1.401.500-PR, Rel. Min. Herman Benjamin. Brasília. DJ 16/08/2016; STJ. 2 ${ }^{\mathrm{a}}$ Turma. Recurso Especial 1.640.243-SC, Rel. Min. Herman Benjamin. Brasília. DJ 07/03/2017; STJ. 2 ${ }^{\mathrm{a}}$ Turma. Recurso Especial 1.251.697-PR, Rel. Min. Mauro Campbell. Brasília. DJ 12/04/2012.

68 STJ. 2a Turma. Recurso Especial 1.401.500-PR, Rel. Min. Herman Benjamin. Brasília. DJ 16/08/2016.

69 STJ. $2^{\text {a }}$ Turma. Recurso Especial 1.401.500-PR, Rel. Min. Herman Benjamin. Brasília. DJ 16/08/2016, p. 14.

70 Afirmou-se que "no Direito brasileiro e de acordo com a jurisprudência do Superior Tribunal de Justiça, a responsabilidade civil pelo dano ambiental, qualquer que seja a qualificação jurídica do degradador, público ou privado, proprietário ou administrador da área degradada, é de natureza objetiva, solidária e ilimitada, sendo regida pelos princípios do poluidor-pagador, da reparação in integrum, da prioridade da reparação in natura e do favor debilis. 4. Todavia, os presentes autos tratam de questão diversa, a saber a natureza da responsabilidade administrativa ambiental, bem como a demonstração de existência ou não de culpa, já que a controvérsia é referente ao cabimento ou não de multa administrativa. 5. Sendo assim, o STJ possui jurisprudência no sentido de que, "tratando-se de responsabilidade administrativa ambiental, o terceiro, proprietário da carga, por não ser o efetivo causador do dano ambiental, responde subjetivamente pela degradação ambiental causada pelo transportador". (STJ. 2 ${ }^{\mathrm{a}}$ Turma. Recurso Especial 1.401.500-PR, Rel. Min. Herman Benjamin. Brasília. DJ 16/08/2016). 
externo ao processo produtivo, suportado por outsiders na hipótese de não internalização. Todavia, todas as situações analisadas são relativas, ou abordam, também a importância da reparação de danos ambientais - ainda que o cerne das discussões jurídicas seja a responsabilidade administrativa ambiental, e não a civil -, o que já permite identificar o porquê de terem sido encontradas ocorrências de palavras-chave que, de alguma forma, expressam a orientação do PPP.

\section{CONCLUSÃO}

De um universo de 2.701 acórdãos selecionados a partir de levantamento com as palavras-chave escolhidas (atualização de 2018) de acordo com a ampla orientação reconhecida ao princípio do poluidorpagador - com vistas à internalização de custos ambientais externos de natureza preventiva e reparatória -, foram analisados em detalhe 208 acórdãos, julgados no âmbito do STJ e STF entre os anos de 1993 e 2018.

Observou-se que as palavras-chave mais recorrentes nos julgados foram "dano e ambiental", e "dano e ambiente", "responsabilidade e civil e ambiental", "degradação e ambiente" e "degradação e ambiental". Os termos "poluidor-pagador" e "poluidor e pagador", que expressam de modo mais direto e explícito o PPP, apareceram em apenas 29 julgados. Devese mencionar, ainda, que, no período em que foi realizada a pesquisa de jurisprudência e sua atualização - de abril de 2014 a abril de 2018 - houve significativo aumento do número de acórdãos selecionados para análise de seu inteiro teor (110 em 2014; 183 em 2017; e 208 em 2018), resultado que, por si só, já evidencia a importância que vem sendo reconhecida ao PPP.

Na quase totalidade dos julgados selecionados, identificou-se a presença da faceta reparatória do PPP. Veja-se que 4 dos 6 grupos temáticos criados para alocação dos acórdãos (G1 a G4) tratam de temas relativos à responsabilidade civil; dos 208 acórdãos selecionados para leitura, 201 trazem questões de responsabilidade civil, o que corresponde a $96,63 \%$ do total de julgados analisados em seu inteiro teor.

Deve-se dizer, ainda, que a predominância da dimensão reparatória do princípio do poluidor-pagador nos resultados da pesquisa jurisprudencial apresenta-se como desdobramento já esperado do entendimento predominante na doutrina brasileira, que limita ou associa quase que automaticamente o PPP à responsabilidade civil, deixando, 
muitas vezes, indevidamente esquecidos seus objetivos preventivos. Embora limitada, esta conotação do princípio não impede que se reconheça que também as regras sobre reparação de danos ambientais são - como devem ser - inspiradas pela proposta de internalização de externalidades ambientais negativas (vez que os danos ambientais são uma das suas formas de expressão), configurando-se, portanto, a responsabilidade civil como importante instrumento de efetivação da dimensão reparatória do princípio do poluidor-pagador.

Neste sentido, pode-se afirmar que o PPP foi importante motor de alteração e posterior pacificação de entendimentos mais protetivos do meio ambiente no que tange à reparação de danos ambientais, promovendo o aperfeiçoamento da interpretação das principais características da responsabilidade civil ambiental. A aplicação do poluidor-pagador, juntamente com outros fundamentos, ${ }^{71}$ contribuiu para que o STJ admitisse: (i) a responsabilidade civil ambiental objetiva e alguns de seus desdobramentos (e.g. não aplicação da teoria do fato consumado em matéria de Direito Ambiental, imprescritibilidade da pretensão de reparação ambiental); (ii) a cumulação da obrigação de fazer, não fazer e pagar, nos casos em que a remediação do impacto ilícito não seja suficiente para a reparação integral do dano ambiental; (iii) a responsabilidade por omissão do Estado como sendo objetiva, solidária e ilimitada, mas de execução subsidiária, evitando-se que a coletividade sofra duplamente com o dano (suportando suas consequências e, ademais, arcando com os custos de sua reparação); (iv) a teoria do risco integral como orientadora da responsabilidade civil ambiental; e (v) o reconhecimento da necessidade da reparação integral do dano ambiental, em seus múltiplos aspectos, inclusive os de ordem extrapatrimonial, sejam individuais ou difusos.

Por outro lado, as características dos julgados analisados denotam que a orientação do princípio do poluidor-pagador relativa à internalização de custos de prevenção de impactos ou danos ambientais ainda não foi apropriada pela jurisprudência brasileira. Esta subutilização do PPP em sua dimensão preventiva indica a necessidade de se explorar mais seu potencial e amplitude, de modo a se alcançar proteção ambiental mais completa e eficiente.

Neste sentido, é possível - e desejável - uma aplicação mais ampla do princípio do poluidor-pagador por parte dos tribunais, de modo a incorporar também seu caráter preventivo e, como consequência,

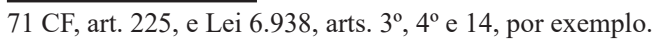


concretizar e aperfeiçoar instrumentos jurídicos destinados à prevenção de impactos e de danos ambientais (e.g. licenciamento ambiental, tributação ambiental etc.).

Espera-se que as decisões judiciais evoluam no sentido de garantir a efetiva internalização das externalidades ambientais negativas, retirando esse ônus da sociedade e transferindo-o para os verdadeiros responsáveis, de modo que o efeito prático da ampla aplicação do princípio do poluidorpagador seja a realização da justiça distributiva em matéria ambiental, com a consequente redução das iniquidades ambientais, especialmente à vista das incertezas, ameaças e gravidade que caracterizam os desafios ambientais atuais.

\section{REFERÊNCIAS}

ARAGÃO, Maria Alexandra de Sousa. Princípio do Poluidor Pagador: pedra angular do Direito Comunitário do Ambiente. ed. 1, 1 vol. Coimbra: Coimbra Editora, 1997.

BENJAMIN, Antonio Herman de Vasconcelos e. O princípio do poluidorpagador e a reparação do dano ambiental. In BENJAMIN, Antonio Herman V. (coord.). Dano Ambiental: Prevenção, Reparação e Repressão. São Paulo: Revista dos Tribunais, 1993, p. 226-236.

CANOTILHO, José Joaquim Gomes; LEITE, José Rubens Morato (orgs.). Direito Constitucional Ambiental Brasileiro. São Paulo: Saraiva, 2007.

CARVALHO FILHO, José dos Santos. Manual de Direito Administrativo. $25^{\circ}$ edição. Rio de Janeiro: Editora Lumen Juris, 2012.

DI PIETRO, Maria Sylvia Zanella. Direito Administrativo. 25a edição. São Paulo: Ed. Atlas, 2012.

D’ISEP, Clarissa Ferreira Macedo. O Princípio do Poluidor-Pagador e sua Aplicação Jurídica: Complexidades, Incertezas e Desafios. In: MARQUES, Cláudia Lima. SILVA, Solange Teles da. (orgs.). O Novo Direito Administrativo, Ambiental e Urbanístico. Rio de Janeiro: Revista dos Tribunais, 2010, p. 291-299.

FIGUEIREDO, Guilherme José Purvin de. A propriedade no Direito Ambiental. $4^{\text {a }}$ ed. São Paulo: Revista dos Tribunais, 2010.

FONSECA, Maria Guadalupe P. da. Iniciação à pesquisa no direito: pelos caminhos do conhecimento e da invenção. Rio de Janeiro: Elsevier, 2009. 
LEUZINGER, Márcia Dieguez e CUREAU, Sandra. Direito Ambiental. $1^{\text {a }}$ Ed. Rio de Janeiro: Editora Campus Jurídico, 2013.

LEITE, José Rubens Morato; AYALA, Patryck de Araújo. Dano ambiental: do individual ao coletivo extrapatrimonial: teoria e prática. 4. ed. rev., atual. e ampl. São Paulo: Revista dos Tribunais, 2011.

LEITE, José Rubens Morato e MOREIRA, Danielle de Andrade. Sociedade de risco, danos ambientais extrapatrimoniais (morais) e a jurisprudência brasileira. Rio de Janeiro: Revista $O A B / R J$, n. 1, v. 24, 2010, p. 107-144.

MACHADO, Paulo Affonso Leme. Direito Ambiental Brasileiro. 20. ed. São Paulo: Malheiros, 2012.

MAZILLI, Hugo Nigro. A Defesa dos Direitos Difusos em Juizo. 19ª ed., rev. e ampl. e atual. São Paulo: Saraiva, 2006.

MELLO, Celso Antônio Bandeira. Curso de Direito Administrativo. 31 edição. São Paulo: Ed. Malheiros, 2014.

MILARÉ, Édis. Direito do Ambiente. $8^{\text {a }}$ Edição. São Paulo: Revista dos Tribunais, 2013.

MIRRA, Álvaro Luiz Valery. Princípios Fundamentais do Direito Ambiental. Revista de Direito Ambiental. São Paulo: Revista dos Tribunais, Vol. 1, 1996, p. 50-66.

MIRRA, Álvaro Luiz Valery. Ação Civil Pública e a reparação do dano ao meio ambiente. $2^{\mathrm{a}}$ ed. São Paulo: Juarez de Oliveira, 2004.

MOREIRA, Danielle de Andrade. Dano ambiental extrapatrimonial. Dissertação (Mestrado em Direito da Cidade) - Faculdade de Direito, Programa de Pós-graduação em Direito, Universidade do Estado do Rio de Janeiro, Rio de Janeiro, 2003.

MOREIRA, Danielle de Andrade. Inversão do Ônus da Prova: STJ, REsp 1.049.822-RS (Rel. Min. Francisco Falcão): Comentário doutrinário. Revista do Superior Tribunal de Justiça, v. 239, 2015, p. 1.202-1.224. (2015a).

MOREIRA, Danielle de Andrade. Princípio do Poluidor-Pagador: Origens, Evolução e Alcance. In: SAMPAIO, Rômulo S.R.; LEAL, Guilherme J. S.; REIS, António Augusto (Org.). Tópicos de Direito Ambiental. 30 Anos da Política Nacional do Meio Ambiente. Rio de Janeiro: Lumen Juris, 2011. p. 29-52. 
MOREIRA, Danielle de Andrade. Responsabilidade ambiental pósconsumo: prevenção e reparação de danos à luz do princípio do poluidorpagador. São Paulo: Letras Jurídicas; Rio de Janeiro: Ed. PUC-Rio, 2015 (2015b).

MOREIRA, Danielle de Andrade. Responsabilidade civil por danos ambientais no direito brasileiro. In: AHMED, Flávio; COUTINHO, Ronaldo. (Org.). Curso de Direito Ambiental. Rio de Janeiro: Lumen Juris, 2012, p. 29-52.

MOREIRA, Danielle de Andrade; GUIMARAES, Virgínia Totti. A complexidade do dano ambiental e seus reflexos na responsabilidade civil e administrativa no brasil: solidariedade e divisão democrática dos riscos e danos. In: Alexandra Aragão; Gisela Maria Bester; Gloriete Marques Alves Hilário. (Org.). Direito e ambiente para uma democracia sustentável: diálogos multidisciplinares entre Portugal e Brasil. 1ed.Curitiba: Instituto Memória. Centro de Estudos da Contemporaneidade, 2015, v. 1, p. $142-$ 171.

MOREIRA, Danielle de Andrade; NEVIANI, F. S. Compensação Ambiental do Sistema Nacional de Unidades de Conservação no Estado do Rio de Janeiro. In: Cristiane Jaccoud. (Org.). Comentários à Legislação Ambiental do Estado do Rio de Janeiro. 1ed.Rio de Janeiro: Lumen Juris, 2017, v. 1, p. 181-221.

NETO GRAU, Werner. O novo paradigma indutor do trato tributário da questão ambiental: do poluidor-pagador ao princípio da sustentabilidade. In: Revista de Direito Ambiental. São Paulo: Revista dos Tribunais, vol. 64.out/dez 2011, p. 11-27.

RODRIGUES, Marcelo Abelha. Elementos de direito ambiental: parte geral. $2^{a}$ ed. rev., atual. e ampl. São Paulo: Revista dos Tribunais, 2005.

SADELEER, Nicolas de. Les Principes du Polluer-Payeur, de Préventiont de Précaution. Essai sur la genèse et la portée juridique de quelques príncipes du droit de l'environnemen. Bruxelas: Bruylan, 1999.

SILVA FILHO, Carlos da Costa e. O Princípio do Poluidor-Pagador: da Eficiência Econômica à Realização da Justiça. In: MOTA, Maurício (org.). Fundamentos Teóricos do Direito Ambiental. Rio de Janeiro: Elsevier, 2008, p. 81-99. 
SILVA, Alceu Calixto. O Princípio do poluidor-pagador na ordem econômica. In: Revista de Direitos Difusos. São Paulo, vol. 24, mar/abr. 2004, p. 3.397-3.405.

SILVEIRA, Clóvis Eduardo Malinverni. A inversão do ônus da prova na reparação do dano ambiental difuso. In: LEITE, José Rubens Morato (Org.); DANTAS, Marcelo Buzaglo (Org.). Aspectos processuais do direito ambiental. Rio de Janeiro: Forense Universitária, 2004. p. 18-31.

STEIGLEDER, Annelise Monteiro. Responsabilidade Civil Ambiental: as dimensões do dano ambiental no direito brasileiro. $2^{\mathrm{a}}$ ed. Porto Alegre: Livraria do Advogado, 2011.

SUPERIOR TRIBUNAL DE JUSTIÇA. Jurisprudência em Teses. Direito Ambiental. N. 30. Brasília, 18 de Março de 2015.

Artigo recebido em: 29/08/2018.

Artigo aceito em: 20/04/2019.

\section{Como citar este artigo (ABNT):}

MOREIRA, D. A.; LIMA, L. M. R. T.; MOREIRA, I. F. O princípio do poluidor-pagador na jurisprudência do STF e do STJ: uma análise crítica. Veredas do Direito, Belo Horizonte, v. 16, n. 34, p. 367-432, jan./abr. 2019. Disponível em: $<$ http://www.domhelder.edu.br/revista/index.php/veredas/ article/view/1341>. Acesso em: dia mês. ano. 


\section{ANEXO (TABELAS COMPLETAS)}

\begin{tabular}{|c|c|c|c|c|}
\hline Decisão (STJ/STF) & ANO & Turma & Relatoria & Palavras-chave \\
\hline STJ Resp20.401-SP & $\begin{array}{l}\text { j. } 1993 \\
\text { p. } 1994\end{array}$ & $2^{\mathrm{a}} \mathrm{T}$ & Min. Hélio Moismann & $\begin{array}{l}\text { dano e ambiente/ } \\
\text { responsabilidade e } \\
\text { civil e ambiental }\end{array}$ \\
\hline STJ Resp214.714-PR & $\begin{array}{l}\text { j. } 1999 \\
\text { p. } 1999\end{array}$ & $1^{\mathrm{a}} \mathrm{T}$ & Min. Garcia Vieira & $\begin{array}{l}\text { responsabilidade e } \\
\text { civil e ambiental }\end{array}$ \\
\hline STJ Resp218.120-PR & $\begin{array}{l}\text { j. } 1999 \\
\text { p. } 1999\end{array}$ & $1^{\mathrm{a}} \mathrm{T}$ & Min. Garcia Vieira & $\begin{array}{l}\text { responsabilidade e } \\
\text { civil e ambiental }\end{array}$ \\
\hline STJ Resp229.302-PR & $\begin{array}{l}\text { j. } 1999 \\
\text { p. } 1999\end{array}$ & $1^{\mathrm{a}} \mathrm{T}$ & Min. Garcia Vieira & $\begin{array}{l}\text { responsabilidade e } \\
\text { civil e ambiental }\end{array}$ \\
\hline STJ Resp222.349-PR & $\begin{array}{l}\text { j. } 2000 \\
\text { p. } 2000\end{array}$ & $1^{\mathrm{a}} \mathrm{T}$. & Min. José Delgado & $\begin{array}{l}\text { responsabilidade e } \\
\text { civil e ambiental }\end{array}$ \\
\hline STJ Resp264.173-PR & $\begin{array}{l}\text { j. } 2001 \\
\text { p. } 2001\end{array}$ & $1^{\mathrm{a}} \mathrm{T}$. & Min. José Delgado & $\begin{array}{l}\text { responsabilidade e } \\
\text { civil e ambiental }\end{array}$ \\
\hline STJ Resp295.797-SP & $\begin{array}{l}\text { j. } 2001 \\
\text { p. } 2001\end{array}$ & $2^{\mathrm{a}} \mathrm{T}$ & Min. Eliana Calmon & $\begin{array}{l}\text { responsabilidade e } \\
\text { civil e ambiental }\end{array}$ \\
\hline $\begin{array}{l}\text { STJ REsp 346.227-SP } \\
\text { (Repetido no G4) }\end{array}$ & $\begin{array}{l}\text { j. } 2001 \\
\text { p. } 2002\end{array}$ & $1^{\mathrm{a}} \mathrm{T}$ & Min. Garcia Vieira & dano e ambiente \\
\hline STJ REsp 115.599-RS & $\begin{array}{l}\text { j. } 2002 \\
\text { p. } 2002\end{array}$ & $4^{\mathrm{a}} \mathrm{T}$ & $\begin{array}{l}\text { Min. Ruy Rosado de } \\
\text { Aguiar }\end{array}$ & $\begin{array}{l}\text { dano e ambiente/ } \\
\text { responsabilidade e } \\
\text { civil e ambiental }\end{array}$ \\
\hline STJ Resp282.781-PR & $\begin{array}{l}\text { j. } 2002 \\
\text { p. } 2002\end{array}$ & $2^{\mathrm{a}} \mathrm{T}$ & Min. Eliana Calmon & $\begin{array}{l}\text { dano e ambiente/ } \\
\text { dano e ambiental/ } \\
\text { responsabilidade e } \\
\text { civil e ambiental }\end{array}$ \\
\hline STJ REsp327.254-PR & $\begin{array}{l}\text { j. } 2002 \\
\text { p. } 2002\end{array}$ & $2^{\mathrm{a}} \mathrm{T}$ & Min. Eliana Calmon & $\begin{array}{l}\text { dano e ambiente/ } \\
\text { dano e ambiental }\end{array}$ \\
\hline STJ REsp343.741-PR & $\begin{array}{l}\text { j. } 2002 \\
\text { p. } 2002\end{array}$ & $2^{\mathrm{a}} \mathrm{T}$ & Min. Franciulli Netto & $\begin{array}{l}\text { dano e ambiente/ } \\
\text { responsabilidade e } \\
\text { civil e ambiental }\end{array}$ \\
\hline STJ REsp217.858-PR & $\begin{array}{l}\text { j. } 2003 \\
\text { p. } 2003\end{array}$ & $2^{\mathrm{a}} \mathrm{T}$ & Min. Franciulli Netto & $\begin{array}{l}\text { responsabilidade e } \\
\text { civil e ambiental }\end{array}$ \\
\hline
\end{tabular}




\begin{tabular}{|c|c|c|c|c|}
\hline $\begin{array}{l}\text { STJ EDcl no AgRg no } \\
\text { REsp 255.170-SP }\end{array}$ & $\begin{array}{l}\text { j. } 2003 \\
\text { p. } 2003\end{array}$ & $1^{\mathrm{a}} \mathrm{T}$ & Min. Luiz Fux & $\begin{array}{l}\text { dano e ambiente/ } \\
\text { responsabilidade e } \\
\text { civil e ambiental }\end{array}$ \\
\hline STJ REsp195.274-PR & $\begin{array}{l}\text { j. } 2005 \\
\text { p. } 2005\end{array}$ & $2^{\mathrm{a}} \mathrm{T}$ & $\begin{array}{l}\text { Min. João Otávio de } \\
\text { Noronha }\end{array}$ & $\begin{array}{l}\text { responsabilidade e } \\
\text { civil e ambiental }\end{array}$ \\
\hline STJ REsp263.383-PR & $\begin{array}{l}\text { j. } 2005 \\
\text { p. } 2005\end{array}$ & $2^{\mathrm{a}} \mathrm{T}$ & $\begin{array}{l}\text { Min. João Otávio de } \\
\text { Noronha }\end{array}$ & $\begin{array}{l}\text { dano e ambiental/ } \\
\text { responsabilidade e } \\
\text { civil e ambiental }\end{array}$ \\
\hline STJ REsp453.875-PR & $\begin{array}{l}\text { j. } 2007 \\
\text { p. } 2009\end{array}$ & $2^{\mathrm{a}} \mathrm{T}$ & Min. Herman Benjamin & $\begin{array}{l}\text { responsabilidade e } \\
\text { civil e ambiental }\end{array}$ \\
\hline STJ REsp650.728-SC & $\begin{array}{l}\text { j. } 2007 \\
\text { p. } 2009\end{array}$ & $2^{\mathrm{a}} \mathrm{T}$ & Min. Herman Benjamin & $\begin{array}{l}\text { degradação } \\
\text { e ambiente / } \\
\text { degradação e } \\
\text { ambiental/ dano } \\
\text { e ambiente/ } \\
\text { responsabilidade e } \\
\text { civil e ambiental }\end{array}$ \\
\hline STJ REsp745.363-PR & $\begin{array}{l}\text { j. } 2007 \\
\text { p. } 2007\end{array}$ & $1^{\mathrm{a}} \mathrm{T}$. & Min. Luiz Fux & $\begin{array}{l}\text { degradação } \\
\text { e ambiente / } \\
\text { degradação } \\
\text { e ambiental / } \\
\text { responsabilidade e } \\
\text { civil e ambiental }\end{array}$ \\
\hline STJ REsp948.921-SP & $\begin{array}{l}\text { j. } 2007 \\
\text { p. } 2009\end{array}$ & $2^{\mathrm{a}} \mathrm{T}$ & Min. Herman Benjamin & $\begin{array}{l}\text { responsabilidade e } \\
\text { civil e ambiental }\end{array}$ \\
\hline $\begin{array}{l}\text { STJ AgRg no RESP } \\
471.864-\text { SP }\end{array}$ & $\begin{array}{l}\text { j. } 2008 \\
\text { p. } 2008\end{array}$ & $1^{\mathrm{a}} \mathrm{T}$. & Min. Francisco Falcão & $\begin{array}{l}\text { dano e ambiente/ } \\
\text { dano e ambiental }\end{array}$ \\
\hline STJ REsp 884.150-MT & $\begin{array}{l}\text { j. } 2008 \\
\text { p. } 2008\end{array}$ & $1^{\mathrm{a}} \mathrm{T}$. & Min. Luiz Fux & $\begin{array}{l}\text { dano e ambiente/ } \\
\text { dano e ambiental }\end{array}$ \\
\hline STJ REsp904.324-RS & $\begin{array}{l}\text { j. } 2008 \\
\text { p. } 2009\end{array}$ & $2^{\mathrm{a}} \mathrm{T}$ & Min. Eliana Calmon & $\begin{array}{l}\text { responsabilidade e } \\
\text { civil e ambiental }\end{array}$ \\
\hline STJ REsp769.753-SC & $\begin{array}{l}\text { j. } 2009 \\
\text { p. } 2011\end{array}$ & $2^{\mathrm{a}} \mathrm{T}$ & Min. Herman Benjamin & $\begin{array}{l}\text { custos e ambiente/ } \\
\text { custos e ambiental/ } \\
\text { degradação } \\
\text { e ambiente/ } \\
\text { degradação } \\
\text { e ambiental/ } \\
\text { poluidor-pagador/ } \\
\text { poluidor e pagador/ } \\
\text { responsabilidade e } \\
\text { civil e ambiental }\end{array}$ \\
\hline
\end{tabular}




\begin{tabular}{|c|c|c|c|c|}
\hline STJ EREsp218.781-PR & $\begin{array}{l}\text { j. } 2009 \\
\text { p. } 2012\end{array}$ & $2^{\mathrm{a}} \mathrm{T}$ & Min. Herman Benjamin & $\begin{array}{l}\text { responsabilidade e } \\
\text { civil e ambiental }\end{array}$ \\
\hline STJ REsp 699.287-AC & $\begin{array}{l}\text { j. } 2009 \\
\text { p. } 2009\end{array}$ & $2^{\mathrm{a}} \mathrm{T}$ & $\begin{array}{l}\text { Min. Mauro Campbell } \\
\text { Marques }\end{array}$ & dano e ambiente \\
\hline STJ REsp 965.078-SP & $\begin{array}{l}\text { j. } 2009 \\
\text { p. } 2011\end{array}$ & $2^{\mathrm{a}} \mathrm{T}$ & Min. Herman Benjamin & $\begin{array}{l}\text { dano e ambiente/ } \\
\text { dano e ambiental }\end{array}$ \\
\hline $\begin{array}{l}\text { STJ REsp1.045.746- } \\
\text { RS }\end{array}$ & $\begin{array}{l}\text { j. } 2009 \\
\text { p. } 2009\end{array}$ & $2^{\mathrm{a}} \mathrm{T}$. & Min. Eliana Calmon & $\begin{array}{l}\text { dano e ambiente/ } \\
\text { dano e ambiental/ } \\
\text { responsabilidade e } \\
\text { civil e ambiental }\end{array}$ \\
\hline $\begin{array}{l}\text { STJ REsp 1.049.822- } \\
\text { RS }\end{array}$ & $\begin{array}{l}\text { j. } 2009 \\
\text { p. } 2009\end{array}$ & $1^{\mathrm{a}} \mathrm{T}$. & Min. Francisco Falcão & $\begin{array}{l}\text { dano e ambiente/ } \\
\text { responsabilidade e } \\
\text { civil e ambiental }\end{array}$ \\
\hline $\begin{array}{l}\text { STJ REsp 1.056.540- } \\
\text { GO }\end{array}$ & $\begin{array}{l}\text { j. } 2009 \\
\text { p. } 2009\end{array}$ & $2^{\mathrm{a}} \mathrm{T}$ & Min. Eliana Calmon & $\begin{array}{l}\text { dano e ambiente/ } \\
\text { responsabilidade e } \\
\text { civil e ambiental }\end{array}$ \\
\hline $\begin{array}{l}\text { STJ REsp 1.058.222- } \\
\text { SP }\end{array}$ & $\begin{array}{l}\text { j. } 2009 \\
\text { p. } 2011\end{array}$ & $2^{\mathrm{a}} \mathrm{T}$ & Min. Herman Benjamin & $\begin{array}{l}\text { dano e ambiente/ } \\
\text { dano e ambiental/ } \\
\text { responsabilidade e } \\
\text { civil e ambiental }\end{array}$ \\
\hline $\begin{array}{l}\text { STJ REsp 1.079.713- } \\
\text { SC }\end{array}$ & $\begin{array}{l}\text { j. } 2009 \\
\text { p. } 2009\end{array}$ & $2^{\mathrm{a}} \mathrm{T}$. & Min. Herman Benjamin & $\begin{array}{l}\text { dano e ambiente/ } \\
\text { dano e ambiental }\end{array}$ \\
\hline $\begin{array}{l}\text { STJ REsp 1.087.370- } \\
\text { PR }\end{array}$ & $\begin{array}{l}\text { j. } 2009 \\
\text { p. } 2009\end{array}$ & $1^{\mathrm{a}} \mathrm{T}$. & Min. Denise Arruda & $\begin{array}{l}\text { responsabilidade e } \\
\text { civil e ambiental }\end{array}$ \\
\hline
\end{tabular}




\begin{tabular}{|c|c|c|c|c|}
\hline STJ REsp 843.978-SP & $\begin{array}{l}\text { j. } 2010 \\
\text { p. } 2012\end{array}$ & $2^{\mathrm{a}} \mathrm{T}$ & Min. Herman Benjamin & $\begin{array}{l}\text { dano e ambiente/ } \\
\text { dano e ambiental/ } \\
\text { degradação } \\
\text { e ambiente/ } \\
\text { degradação } \\
\text { e ambiental/ } \\
\text { responsabilidade e } \\
\text { civil e ambiental }\end{array}$ \\
\hline STJ REsp 880.160-RJ & $\begin{array}{l}\text { j. } 2010 \\
\text { p. } 2010\end{array}$ & $2^{\mathrm{a}} \mathrm{T}$ & $\begin{array}{l}\text { Min. Mauro Campbell } \\
\text { Marques }\end{array}$ & $\begin{array}{l}\text { custos e ambiente/ } \\
\text { degradação } \\
\text { e ambiente / } \\
\text { degradação e } \\
\text { ambiental/ dano } \\
\text { e ambiente/ } \\
\text { responsabilidade e } \\
\text { civil e ambiental }\end{array}$ \\
\hline $\begin{array}{l}\text { STJ REsp 967.375- } \\
\text { RJ }\end{array}$ & $\begin{array}{l}\text { j. } 2010 \\
\text { p. } 2010\end{array}$ & $2^{\mathrm{a}} \mathrm{T}$ & Min. Eliana Calmon & $\begin{array}{l}\text { poluidor e } \\
\text { pagador }\end{array}$ \\
\hline $\begin{array}{l}\text { STJ REsp 1.069.155- } \\
\text { SC }\end{array}$ & $\begin{array}{l}\text { j. } 2010 \\
\text { p. } 2011\end{array}$ & $2^{\mathrm{a}} \mathrm{T}$ & $\begin{array}{l}\text { Min. Mauro } \\
\text { Campbell Marques }\end{array}$ & $\begin{array}{l}\text { dano e ambiente/ } \\
\text { dano e ambiental/ } \\
\text { responsabilidade } \\
\text { e civil e } \\
\text { ambiental }\end{array}$ \\
\hline $\begin{array}{l}\text { STJ REsp 1.090.968- } \\
\text { SP }\end{array}$ & $\begin{array}{l}\text { j. } 2010 \\
\text { p. } 2010\end{array}$ & $1^{\mathrm{a}} \mathrm{T}$ & Min. Luiz Fux & $\begin{array}{l}\text { degradação } \\
\text { e ambiente / } \\
\text { degradação e } \\
\text { ambiental/ dano } \\
\text { e ambiente/ } \\
\text { responsabilidade } \\
\text { e civil e } \\
\text { ambiental }\end{array}$ \\
\hline
\end{tabular}




\begin{tabular}{|c|c|c|c|c|}
\hline $\begin{array}{l}\text { STJ REsp 1.107.219- } \\
\text { SP }\end{array}$ & $\begin{array}{l}\text { j. } 2010 \\
\text { p. } 2010\end{array}$ & $1^{\mathrm{a}} \mathrm{T}$ & Min. Luiz Fux & $\begin{array}{l}\text { dano e ambiente/ } \\
\text { responsabilidade } \\
\text { e civil e } \\
\text { ambiental }\end{array}$ \\
\hline $\begin{array}{l}\text { STJ REsp 1.186.130- } \\
\text { RJ }\end{array}$ & $\begin{array}{l}\text { j. } 2010 \\
\text { p. } 2012\end{array}$ & $2^{\mathrm{a}} \mathrm{T}$ & $\begin{array}{l}\text { Min. Herman } \\
\text { Benjamin }\end{array}$ & $\begin{array}{l}\text { dano e ambiente/ } \\
\text { responsabilidade } \\
\text { e civil e } \\
\text { ambiental }\end{array}$ \\
\hline $\begin{array}{l}\text { STJ EDcl no Ag } \\
1.224 .056-\mathrm{SP}\end{array}$ & $\begin{array}{l}\text { j. } 2010 \\
\text { p. } 2010\end{array}$ & $2^{\mathrm{a}} \mathrm{T}$ & $\begin{array}{l}\text { Min. Mauro } \\
\text { Campbell Marques }\end{array}$ & $\begin{array}{l}\text { degradação e } \\
\text { ambiental/ dano e } \\
\text { ambiental }\end{array}$ \\
\hline $\begin{array}{l}\text { STJ AgRg no RESP } \\
1.121 .233-\mathrm{SP}\end{array}$ & $\begin{array}{l}\text { j. } 2010 \\
\text { p. } 2011\end{array}$ & $1^{\mathrm{a}} \mathrm{T}$. & $\begin{array}{l}\text { Min. Arnaldo Esteves } \\
\text { Lima }\end{array}$ & $\begin{array}{l}\text { dano e ambiente/ } \\
\text { dano e ambiental }\end{array}$ \\
\hline $\begin{array}{l}\text { STJ REsp1.164.630- } \\
\text { MG }\end{array}$ & $\begin{array}{l}\text { j. } 2010 \\
\text { p. } 2010\end{array}$ & $2^{\mathrm{a}} \mathrm{T}$ & Min. Castro Meira & $\begin{array}{l}\text { dano e ambiente/ } \\
\text { dano e ambiental }\end{array}$ \\
\hline $\begin{array}{l}\text { STJ EDcl nos EDcl } \\
\text { no Ag 1.323.337-SP }\end{array}$ & $\begin{array}{l}\text { j. } 2011 \\
\text { p. } 2011\end{array}$ & $2^{\mathrm{a}} \mathrm{T}$ & $\begin{array}{l}\text { Min.MauroCampbell } \\
\text { Marques }\end{array}$ & $\begin{array}{l}\text { d e g r a d a ç ã o } \\
\text { e ambiente } \\
\text { degradação } \\
\text { ambiental/ dano e } \\
\text { ambiente }\end{array}$ \\
\hline $\begin{array}{l}\text { STJ AgRg no } \\
\text { REsp1.001.780-PR } \\
\text { (Repetido no G3) }\end{array}$ & $\begin{array}{l}\text { j. } 2011 \\
\text { p. } 2011\end{array}$ & $1^{\mathrm{a}} \mathrm{T}$. & $\begin{array}{l}\text { Min. Teori Albino } \\
\text { Zavascki }\end{array}$ & $\begin{array}{l}\text { d e g r a d a ç ã o } \\
\text { e ambiente } \\
\text { degradação } \\
\text { ambiental/ dano } \\
\text { e ambiente/ } \\
\text { responsabilidadee } \\
\text { civil e ambiental }\end{array}$ \\
\hline
\end{tabular}




\begin{tabular}{|c|c|c|c|c|}
\hline $\begin{array}{l}\text { STJ AgRg no } \\
\text { REsp1.206.484-SP }\end{array}$ & $\begin{array}{l}\text { j. } 2011 \\
\text { p. } 2011\end{array}$ & $2^{\mathrm{a}} \mathrm{T}$ & $\begin{array}{l}\text { Min. Humberto } \\
\text { Martins }\end{array}$ & $\begin{array}{l}\text { dano e ambiente/ } \\
\text { dano e ambiental }\end{array}$ \\
\hline $\begin{array}{l}\text { STJ REsp } \\
1.237 .071-\mathrm{PR}\end{array}$ & $\begin{array}{l}\text { j. } 2011 \\
\text { p. } 2011\end{array}$ & $2^{\mathrm{a}} \mathrm{T}$ & $\begin{array}{l}\text { Min. Humberto } \\
\text { Martins }\end{array}$ & $\begin{array}{l}\text { custos e } \\
\text { ambiente/custos } \\
\text { e ambiental/dano } \\
\text { e ambiente/dano } \\
\text { e ambiental/ } \\
\text { degradação } \\
\text { e ambiente/ } \\
\text { degradação e } \\
\text { ambiental/ }\end{array}$ \\
\hline $\begin{array}{l}\text { STJ REsp } \\
1.240 .122-\mathrm{PR}\end{array}$ & $\begin{array}{l}\text { j. } 2011 \\
\text { p. } 2011\end{array}$ & $2^{\mathrm{a}} \mathrm{T}$ & $\begin{array}{l}\text { Min. Herman } \\
\text { Benjamin }\end{array}$ & $\begin{array}{l}\text { degradação } \\
\text { e ambiente / } \\
\text { degradação e } \\
\text { ambiental/ dano e } \\
\text { ambiente }\end{array}$ \\
\hline $\begin{array}{l}\text { STJ REsp } \\
1.246 .443-\mathrm{PR}\end{array}$ & $\begin{array}{l}\text { j. } 2011 \\
\text { p. } 2012\end{array}$ & $2^{\mathrm{a}} \mathrm{T}$ & $\begin{array}{l}\text { Min. Mauro } \\
\text { Campbell Marques }\end{array}$ & $\begin{array}{l}\text { dano e ambiente/ } \\
\text { dano e ambiental }\end{array}$ \\
\hline $\begin{array}{l}\text { STJ REsp } \\
1.247 .140-\mathrm{PR}\end{array}$ & $\begin{array}{l}\text { j. } 2011 \\
\text { p. } 2011\end{array}$ & $2^{\mathrm{a}} \mathrm{T}$ & $\begin{array}{l}\text { Min. Mauro } \\
\text { Campbell Marques }\end{array}$ & $\begin{array}{l}\text { degradação e } \\
\text { ambiental/ dano } \\
\text { e ambiental/ } \\
\text { responsabilidade } \\
\text { e civil e } \\
\text { ambiental }\end{array}$ \\
\hline $\begin{array}{l}\text { STJ AgRg no } \\
\text { AREsp173.000-MG }\end{array}$ & $\begin{array}{l}\text { j. } 2012 \\
\text { p. } 2012\end{array}$ & $4^{\mathrm{a}} \mathrm{T}$ & $\begin{array}{l}\text { Min. Antonio Carlos } \\
\text { Ferreira }\end{array}$ & $\begin{array}{l}\text { dano e ambiental/ } \\
\text { responsabilidade } \\
\text { e civil e } \\
\text { ambiental }\end{array}$ \\
\hline $\begin{array}{l}\text { STJ REsp } \\
1.285 .463-\mathrm{SP}\end{array}$ & $\begin{array}{l}\text { j. } 2012 \\
\text { p. } 2012\end{array}$ & $2^{\mathrm{a}} \mathrm{T}$ & $\begin{array}{l}\text { Min. Humberto } \\
\text { Martins }\end{array}$ & $\begin{array}{l}\text { dano e ambiente/ } \\
\text { dano e ambiental/ } \\
\text { degradação } \\
\text { e ambiental/ } \\
\text { degradação e } \\
\text { ambiente }\end{array}$ \\
\hline
\end{tabular}




\begin{tabular}{|c|c|c|c|c|}
\hline $\begin{array}{l}\text { STJ AgRg no } \\
\text { REsp1.286.142-SC }\end{array}$ & $\begin{array}{l}\text { j. } 2013 \\
\text { p. } 2013\end{array}$ & $2^{\mathrm{a}} \mathrm{T}$ & $\begin{array}{l}\text { Min. Mauro } \\
\text { Campbell Marques }\end{array}$ & $\begin{array}{l}\text { dano e ambiente/ } \\
\text { responsabilidade } \\
\text { e civil e } \\
\text { ambiental }\end{array}$ \\
\hline $\begin{array}{l}\text { STJ REsp1.346.489- } \\
\text { RS } \\
\text { (Repetido no G2) }\end{array}$ & $\begin{array}{l}\text { j. } 2013 \\
\text { p. } 2013\end{array}$ & $3^{\mathrm{a}} \mathrm{T}$ & $\begin{array}{l}\text { Min. Ricardo Villas } \\
\text { Bôas Cueva }\end{array}$ & dano e ambiental \\
\hline $\begin{array}{l}\text { STJ AgRg no } \\
\text { AREsp223.858-SP }\end{array}$ & $\begin{array}{l}\text { j. } 2014 \\
\text { p. } 2014\end{array}$ & $4^{\mathrm{a}} \mathrm{T}$ & $\begin{array}{l}\text { Min. Luis Felipe } \\
\text { Salomão }\end{array}$ & dano e ambiental \\
\hline $\begin{array}{l}\text { STJ AgRg no } \\
\text { AREsp231.561-MG }\end{array}$ & $\begin{array}{l}\text { j. } 2014 \\
\text { p. } 2015\end{array}$ & $2^{\mathrm{a}} \mathrm{T}$ & $\begin{array}{l}\text { Min. Herman } \\
\text { Benjamin }\end{array}$ & $\begin{array}{l}\text { degradação } \\
\text { e ambiente / } \\
\text { degradação e } \\
\text { ambiental }\end{array}$ \\
\hline $\begin{array}{l}\text { STJ AgRg no } \\
\text { REsp1.391.259-SP }\end{array}$ & $\begin{array}{l}\text { j. } 2014 \\
\text { p. } 2015\end{array}$ & $3^{\mathrm{a}} \mathrm{T}$ & $\begin{array}{l}\text { Min. Paulo de Tarso } \\
\text { Sanseverino }\end{array}$ & dano e ambiental \\
\hline $\begin{array}{l}\text { STJ AgRg no } \\
\text { REsp1.421.163-SP }\end{array}$ & $\begin{array}{l}\text { j. } 2014 \\
\text { p. } 2014\end{array}$ & $2^{\mathrm{a}} \mathrm{T}$ & $\begin{array}{l}\text { Min. Humberto } \\
\text { Martins }\end{array}$ & $\begin{array}{l}\text { dano e ambiente/ } \\
\text { dano e ambiental/ } \\
\text { degradação } \\
\text { e ambiente/ } \\
\text { degradação e } \\
\text { ambiental }\end{array}$ \\
\hline $\begin{array}{l}\text { STJ REsp684753- } \\
\text { PR }\end{array}$ & $\begin{array}{l}\text { j. } 2014 \\
\text { p. } 2014\end{array}$ & $4^{\mathrm{a}} \mathrm{T}$. & $\begin{array}{l}\text { Min. Antonio Carlos } \\
\text { Ferreira }\end{array}$ & $\begin{array}{l}\text { dano e ambiente/ } \\
\text { dano e ambiental/ } \\
\text { degradação } \\
\text { e ambiente/ } \\
\text { degradação } \\
\text { em ambiental/ } \\
\text { responsabilidade } \\
\text { e civil e } \\
\text { ambiental }\end{array}$ \\
\hline
\end{tabular}




\begin{tabular}{|c|c|c|c|c|}
\hline $\begin{array}{l}\text { STJ AgRg no } \\
\text { AREsp183.202-SP }\end{array}$ & $\begin{array}{l}\text { j. } 2015 \\
\text { p. } 2015\end{array}$ & $3^{\mathrm{a}} \mathrm{T}$ & $\begin{array}{l}\text { Min. Ricardo Villas } \\
\text { Bôas Cueva }\end{array}$ & $\begin{array}{l}\text { dano e ambiente/ } \\
\text { dano e ambiental/ } \\
\text { responsabilidade } \\
\text { e civil e } \\
\text { ambiental }\end{array}$ \\
\hline $\begin{array}{l}\text { STJ AgRg no } \\
\text { AREsp533.786-SP }\end{array}$ & $\begin{array}{l}\text { j. } 2015 \\
\text { p. } 2015\end{array}$ & $4^{\mathrm{a}} \mathrm{T}$ & $\begin{array}{l}\text { Min. Antonio Carlos } \\
\text { Ferreira }\end{array}$ & $\begin{array}{l}\text { dano e ambiental/ } \\
\text { responsabilidade } \\
\text { e civil e } \\
\text { ambiental }\end{array}$ \\
\hline $\begin{array}{l}\text { STJ AgRg no } \\
\text { AREsp548.908-DF }\end{array}$ & $\begin{array}{l}\text { j. } 2015 \\
\text { p. } 2015\end{array}$ & $2^{\mathrm{a}} \mathrm{T}$ & $\begin{array}{ll}\text { Min. } & \text { Herman } \\
\text { Benjamin } & \end{array}$ & $\begin{array}{l}\text { dano e ambiental/ } \\
\text { responsabilidadee } \\
\text { civil e ambiental }\end{array}$ \\
\hline $\begin{array}{l}\text { STJ AgRg no } \\
\text { AREsp616.105-RJ }\end{array}$ & $\begin{array}{l}\text { j. } 2015 \\
\text { p. } 2015\end{array}$ & $3^{\mathrm{a}} \mathrm{T}$ & $\begin{array}{l}\text { Min. Marco Aurélio } \\
\text { Bellizze }\end{array}$ & $\begin{array}{l}\text { dano e ambiental/ } \\
\text { responsabilidadee } \\
\text { civil e ambiental }\end{array}$ \\
\hline $\begin{array}{l}\text { STJ AgRg no } \\
\text { AREsp689.997-SP }\end{array}$ & $\begin{array}{l}\text { j. } 2015 \\
\text { p. } 2016\end{array}$ & $3^{\mathrm{a}} \mathrm{T}$ & $\begin{array}{l}\text { Min. Ricardo Villas } \\
\text { Bôas Cueva }\end{array}$ & $\begin{array}{l}\text { dano e ambiente/ } \\
\text { dano e ambiental }\end{array}$ \\
\hline $\begin{array}{l}\text { STJ AgRg no } \\
\text { AREsp737.887-SE }\end{array}$ & $\begin{array}{l}\text { j. } 2015 \\
\text { p. } 2015\end{array}$ & $2^{\mathrm{a}} \mathrm{T}$ & $\begin{array}{l}\text { Min. Humberto } \\
\text { Martins }\end{array}$ & $\begin{array}{l}\text { dano e ambiente/ } \\
\text { dano e ambiental }\end{array}$ \\
\hline $\begin{array}{l}\text { STJ AgRg no } \\
\text { REsp1.417.023-PR }\end{array}$ & $\begin{array}{l}\text { j. } 2015 \\
\text { p. } 2015\end{array}$ & $2^{\mathrm{a}} \mathrm{T}$ & $\begin{array}{l}\text { Min. Humberto } \\
\text { Martins }\end{array}$ & $\begin{array}{l}\text { dano e ambiente/ } \\
\text { dano e ambiental/ } \\
\text { responsabilidadee } \\
\text { civil e ambiental }\end{array}$ \\
\hline $\begin{array}{l}\text { STJ AgRg no } \\
\text { REsp1.494.012-PE }\end{array}$ & $\begin{array}{l}\text { j. } 2015 \\
\text { p. } 2015\end{array}$ & $2^{\mathrm{a}} \mathrm{T}$ & $\begin{array}{l}\text { Min.MauroCampbell } \\
\text { Marques }\end{array}$ & $\begin{array}{l}\text { responsabilidadee } \\
\text { civil e ambiental }\end{array}$ \\
\hline $\begin{array}{l}\text { STJ AgRg no } \\
\text { REsp1.494.681-MS }\end{array}$ & $\begin{array}{l}\text { j. } 2015 \\
\text { p. } 2015\end{array}$ & $2^{\mathrm{a}} \mathrm{T}$ & $\begin{array}{l}\text { Min. Humberto } \\
\text { Martins }\end{array}$ & $\begin{array}{l}\text { dano e ambiente/ } \\
\text { dano e ambiental/ } \\
\text { d e g r a d a ç ã o } \\
\text { e ambiente/ } \\
\text { degradação } \\
\text { ambiental }\end{array}$ \\
\hline
\end{tabular}




\begin{tabular}{|c|c|c|c|c|}
\hline $\begin{array}{l}\text { STJ AgRg no } \\
\text { REsp1.494.792-SP }\end{array}$ & $\begin{array}{l}\text { j. } 2015 \\
\text { p. } 2015\end{array}$ & $2^{\mathrm{a}} \mathrm{T}$ & $\begin{array}{l}\text { Min.MauroCampbell } \\
\text { Marques }\end{array}$ & $\begin{array}{l}\text { dano e ambiente/ } \\
\text { dano e ambiental }\end{array}$ \\
\hline $\begin{array}{l}\text { STJ AgRg no } \\
\text { REsp1.494.988-MS }\end{array}$ & $\begin{array}{l}\text { j. } 2015 \\
\text { p. } 2015\end{array}$ & $2^{\mathrm{a}} \mathrm{T}$ & $\begin{array}{l}\text { Min. } \quad \text { Humberto } \\
\text { Martins }\end{array}$ & $\begin{array}{l}\text { dano e ambiente/ } \\
\text { dano e ambiental }\end{array}$ \\
\hline $\begin{array}{l}\text { STJ AgRg no } \\
\text { REsp1.512.655-MG }\end{array}$ & $\begin{array}{l}\text { j. } 2015 \\
\text { p. } 2015\end{array}$ & $2^{\mathrm{a}} \mathrm{T}$ & $\begin{array}{l}\text { Min. Assusete } \\
\text { Magalhães }\end{array}$ & $\begin{array}{l}\text { dano e ambiente/ } \\
\text { dano e ambiental }\end{array}$ \\
\hline $\begin{array}{l}\text { STJ AgRg no } \\
\text { REsp1.513.156-CE }\end{array}$ & $\begin{array}{l}\text { j. } 2015 \\
\text { p. } 2015\end{array}$ & $2^{\mathrm{a}} \mathrm{T}$ & $\begin{array}{l}\text { Min. Humberto } \\
\text { Martins }\end{array}$ & $\begin{array}{l}\text { dano e ambiental/ } \\
\text { responsabilidadee } \\
\text { civil e ambiental }\end{array}$ \\
\hline $\begin{array}{l}\text { STJ REsp1.241.630- } \\
\text { PR }\end{array}$ & $\begin{array}{l}\text { j. } 2015 \\
\text { p. } 2017\end{array}$ & $2^{\mathrm{a}} \mathrm{T}$ & $\begin{array}{ll}\text { Min. } & \text { Humberto } \\
\text { Martins } & \end{array}$ & $\begin{array}{l}\text { dano e ambiente/ } \\
\text { dano e ambiental/ } \\
\text { d e g r a d a ç ã o } \\
\text { e ambiente/ } \\
\text { degradação } \\
\text { ambiental }\end{array}$ \\
\hline $\begin{array}{l}\text { STJ REsp1.344.525- } \\
\text { SC }\end{array}$ & $\begin{array}{l}\text { j. } 2015 \\
\text { p. } 2015\end{array}$ & $2^{\mathrm{a}} \mathrm{T}$ & $\begin{array}{l}\text { Min. Herman } \\
\text { Benjamin }\end{array}$ & $\begin{array}{l}\text { dano e ambiente/ } \\
\text { dano e ambiental }\end{array}$ \\
\hline $\begin{array}{l}\text { STJ REsp1.363.107- } \\
\text { DF }\end{array}$ & $\begin{array}{l}\text { j. } 2015 \\
\text { p. } 2015\end{array}$ & $3^{\mathrm{a}} \mathrm{T}$ & $\begin{array}{l}\text { Min. Paulo de Tarso } \\
\text { Sanseverino }\end{array}$ & $\begin{array}{l}\text { dano e ambiente/ } \\
\text { dano e ambiental/ } \\
\text { responsabilidadee } \\
\text { civil e ambiental }\end{array}$ \\
\hline $\begin{array}{l}\text { STJ REsp1.370.125- } \\
\text { PR }\end{array}$ & $\begin{array}{l}\text { j. } 2015 \\
\text { p. } 2015\end{array}$ & $4^{\mathrm{a}} \mathrm{T}$ & $\begin{array}{l}\text { Min. Maria Isabel } \\
\text { Gallotti }\end{array}$ & $\begin{array}{l}\text { dano e ambiente/ } \\
\text { dano e ambiental/ } \\
\text { degradação } \\
\text { e ambiente/ } \\
\text { degradação } \\
\text { e ambiental/ } \\
\text { responsabilidade } \\
\text { e civil e } \\
\text { ambiental }\end{array}$ \\
\hline
\end{tabular}




\begin{tabular}{|c|c|c|c|c|}
\hline $\begin{array}{l}\text { STJ REsp1.371.834- } \\
\text { PR }\end{array}$ & $\begin{array}{l}\text { j. } 2015 \\
\text { p. } 2015\end{array}$ & $4^{\mathrm{a}} \mathrm{T}$ & $\begin{array}{l}\text { Min. Maria Isabel } \\
\text { Gallotti }\end{array}$ & $\begin{array}{l}\text { dano e ambiente/ } \\
\text { dano e ambiental/ } \\
\text { degradação } \\
\text { e ambiente/ } \\
\text { degradação } \\
\text { e ambiental/ } \\
\text { responsabilidade } \\
\text { e civil e } \\
\text { ambiental }\end{array}$ \\
\hline $\begin{array}{l}\text { STJ REsp1.507.617- } \\
\text { AL }\end{array}$ & $\begin{array}{l}\text { j. } 2015 \\
\text { p. } 2015\end{array}$ & $2^{\mathrm{a}} \mathrm{T}$ & $\begin{array}{l}\text { Min. Humberto } \\
\text { Martins }\end{array}$ & dano e ambiental \\
\hline $\begin{array}{l}\text { STJ REsp1.517.403- } \\
\text { AL }\end{array}$ & $\begin{array}{l}\text { j. } 2015 \\
\text { p. } 2015\end{array}$ & $2^{\mathrm{a}} \mathrm{T}$ & $\begin{array}{l}\text { Min. Herman } \\
\text { Benjamin }\end{array}$ & $\begin{array}{l}\text { dano e ambiente/ } \\
\text { dano e ambiental/ } \\
\text { degradação } \\
\text { e ambiente/ } \\
\text { degradação } \\
\text { e ambiental/ } \\
\text { responsabilidade } \\
\text { e civil e } \\
\text { ambiental }\end{array}$ \\
\hline $\begin{array}{l}\text { STJ AgInt no } \\
\text { AREsp.768.842-PR }\end{array}$ & $\begin{array}{l}\text { j. } 2016 \\
\text { p. } 2016\end{array}$ & $3^{\mathrm{a}} \mathrm{T}$ & $\begin{array}{l}\text { Min. Marco Aurélio } \\
\text { Bellizze }\end{array}$ & $\begin{array}{l}\text { dano e ambiental/ } \\
\text { responsabilidade } \\
\text { e civil e } \\
\text { ambiental }\end{array}$ \\
\hline
\end{tabular}




\begin{tabular}{|c|c|c|c|c|}
\hline $\begin{array}{l}\text { STJ AgInt no } \\
\text { AREsp.839.492-SP }\end{array}$ & $\begin{array}{l}\text { j. } 2016 \\
\text { p. } 2017\end{array}$ & $2^{\mathrm{a}} \mathrm{T}$ & $\begin{array}{l}\text { Min. Herman } \\
\text { Benjamin }\end{array}$ & $\begin{array}{l}\text { dano e ambiente/ } \\
\text { dano e ambiental/ } \\
\text { degradação } \\
\text { e ambiente/ } \\
\text { degradação } \\
\text { e ambiental/ } \\
\text { responsabilidade } \\
\text { e civil e } \\
\text { ambiental }\end{array}$ \\
\hline $\begin{array}{l}\text { STJ AgInt nos EDcl } \\
\text { no REsp.1.447.071- } \\
\text { MS }\end{array}$ & $\begin{array}{l}\text { j. } 2016 \\
\text { p. } 2017\end{array}$ & $2^{\mathrm{a}} \mathrm{T}$ & $\begin{array}{l}\text { Min. Herman } \\
\text { Benjamin }\end{array}$ & $\begin{array}{l}\text { dano e ambiente/ } \\
\text { dano e ambiental }\end{array}$ \\
\hline $\begin{array}{l}\text { STJ AgInt no EDcl } \\
\text { no REsp.1.468.747- } \\
\text { MS }\end{array}$ & $\begin{array}{l}\text { j. } 2016 \\
\text { p. } 2017\end{array}$ & $2^{\mathrm{a}} \mathrm{T}$ & $\begin{array}{l}\text { Min. Herman } \\
\text { Benjamin }\end{array}$ & $\begin{array}{l}\text { dano e ambiente/ } \\
\text { dano e ambiental }\end{array}$ \\
\hline $\begin{array}{l}\text { STJ RHC 64.124- } \\
\text { MS }\end{array}$ & $\begin{array}{l}\text { j. } 2016 \\
\text { p. } 2016\end{array}$ & $5^{\mathrm{a}} \mathrm{T}$ & $\begin{array}{l}\text { Min. Reynaldo } \\
\text { Soares da Fonseca }\end{array}$ & $\begin{array}{l}\text { dano e ambiente/ } \\
\text { dano e ambiental/ } \\
\text { responsabilidade } \\
\text { e civil e } \\
\text { ambiental }\end{array}$ \\
\hline $\begin{array}{l}\text { STJ RHC 64.219- } \\
\text { MS }\end{array}$ & $\begin{array}{l}\text { j. } 2016 \\
\text { p. } 2016\end{array}$ & $5^{\mathrm{a}} \mathrm{T}$ & $\begin{array}{l}\text { Min. Reynaldo } \\
\text { Soares da Fonseca }\end{array}$ & $\begin{array}{l}\text { dano e ambiente/ } \\
\text { dano e ambiental/ } \\
\text { responsabilidade } \\
\text { e civil e } \\
\text { ambiental }\end{array}$ \\
\hline $\begin{array}{l}\text { STJ AgRg no } \\
\text { AREsp479.026-SP }\end{array}$ & $\begin{array}{l}\text { j. } 2016 \\
\text { p. } 2016\end{array}$ & $1^{\mathrm{a}} \mathrm{T}$ & $\begin{array}{l}\text { Min. Regina Helena } \\
\text { Costa }\end{array}$ & $\begin{array}{l}\text { responsabilidade } \\
\text { e civil e } \\
\text { ambiental }\end{array}$ \\
\hline $\begin{array}{l}\text { STJ AgRg no } \\
\text { AREsp820.915-MA }\end{array}$ & $\begin{array}{l}\text { j. } 2016 \\
\text { p. } 2016\end{array}$ & $4^{\mathrm{a}} \mathrm{T}$ & $\begin{array}{l}\text { Min. Luis Felipe } \\
\text { Salomão }\end{array}$ & dano e ambiental \\
\hline
\end{tabular}




\begin{tabular}{|c|c|c|c|c|}
\hline $\begin{array}{l}\text { STJ AgRg nos EDcl } \\
\text { no REsp1.381.341- } \\
\text { MS }\end{array}$ & $\begin{array}{l}\text { j. } 2016 \\
\text { p. } 2016\end{array}$ & $2^{\mathrm{a}} \mathrm{T}$ & $\begin{array}{l}\text { Min. Humberto } \\
\text { Martins }\end{array}$ & $\begin{array}{l}\text { dano e ambiente/ } \\
\text { dano e ambiental }\end{array}$ \\
\hline $\begin{array}{l}\text { STJ AgRg no } \\
\text { REsp1.500.062-MT }\end{array}$ & $\begin{array}{l}\text { j. } 2016 \\
\text { p. } 2016\end{array}$ & $1^{\mathrm{a}} \mathrm{T}$. & $\begin{array}{l}\text { Min. Regina Helena } \\
\text { Costa }\end{array}$ & $\begin{array}{l}\text { dano e ambiente/ } \\
\text { dano e ambiental/ } \\
\text { responsabilidade } \\
\text { e civil e } \\
\text { ambiental }\end{array}$ \\
\hline $\begin{array}{l}\text { STJ EDcl no } \\
\text { REsp1.517.403-AL }\end{array}$ & $\begin{array}{l}\text { j. } 2016 \\
\text { p. } 2016\end{array}$ & $2^{\mathrm{a}} \mathrm{T}$ & $\begin{array}{l}\text { Min. Herman } \\
\text { Benjamin }\end{array}$ & $\begin{array}{l}\text { dano e ambiental/ } \\
\text { degradação } \\
\text { e ambiental/ } \\
\text { responsabilidade } \\
\text { e civil e } \\
\text { ambiental }\end{array}$ \\
\hline $\begin{array}{l}\text { STJ REsp1.407.649- } \\
\text { CE }\end{array}$ & $\begin{array}{l}\text { j. } 2016 \\
\text { p. } 2016\end{array}$ & $2^{\mathrm{a}} \mathrm{T}$ & $\begin{array}{l}\text { Min. Herman } \\
\text { Benjamin }\end{array}$ & dano e ambiente \\
\hline $\begin{array}{l}\text { STJ REsp1.559.396- } \\
\text { MG }\end{array}$ & $\begin{array}{l}\text { j. } 2016 \\
\text { p. } 2016\end{array}$ & $2^{\mathrm{a}} \mathrm{T}$ & $\begin{array}{l}\text { Min. Herman } \\
\text { Benjamin }\end{array}$ & $\begin{array}{l}\text { dano e ambiente/ } \\
\text { dano e ambiental }\end{array}$ \\
\hline $\begin{array}{l}\text { STJ REsp1.622.512- } \\
\text { RJ }\end{array}$ & $\begin{array}{l}\text { j. } 2016 \\
\text { p. } 2016\end{array}$ & $2^{\mathrm{a}} \mathrm{T}$ & $\begin{array}{l}\text { Min. Herman } \\
\text { Benjamin }\end{array}$ & $\begin{array}{l}\text { dano e ambiente/ } \\
\text { dano e ambiental/ } \\
\text { responsabilidade } \\
\text { e civil e } \\
\text { ambiental }\end{array}$ \\
\hline $\begin{array}{l}\text { STJ AgInt no } \\
\text { REsp1.382.576-MS }\end{array}$ & $\begin{array}{l}\text { j. } 2017 \\
\text { p. } 2017\end{array}$ & $2^{\mathrm{a}} \mathrm{T}$ & $\begin{array}{l}\text { Min. Assusete } \\
\text { Magalhães }\end{array}$ & $\begin{array}{l}\text { dano e ambiente/ } \\
\text { dano e ambiental/ } \\
\text { responsabilidade } \\
\text { e civil e } \\
\text { ambiental }\end{array}$ \\
\hline
\end{tabular}




\begin{tabular}{|c|c|c|c|c|}
\hline $\begin{array}{l}\text { STJ AgInt no } \\
\text { REsp1.389.613-MS }\end{array}$ & $\begin{array}{l}\text { j. } 2017 \\
\text { p. } 2017\end{array}$ & $2^{\mathrm{a}} \mathrm{T}$ & $\begin{array}{l}\text { Min. Assusete } \\
\text { Magalhães }\end{array}$ & $\begin{array}{l}\text { dano e ambiente/ } \\
\text { dano e ambiental/ } \\
\text { responsabilidade } \\
\text { e civil e } \\
\text { ambiental }\end{array}$ \\
\hline $\begin{array}{l}\text { STJ AgInt no } \\
\text { REsp1.565.568-PR }\end{array}$ & $\begin{array}{l}\text { j. } 2017 \\
\text { p. } 2017\end{array}$ & $3^{\mathrm{a}} \mathrm{T}$ & Min. Nancy Andrighi & $\begin{array}{l}\text { dano e ambiente/ } \\
\text { dano e ambiental }\end{array}$ \\
\hline $\begin{array}{l}\text { STJ AgRg no } \\
\text { REsp1.223.499-SP }\end{array}$ & $\begin{array}{l}\text { j. } 2017 \\
\text { p. } 2017\end{array}$ & $1^{\mathrm{a}} \mathrm{T}$. & $\begin{array}{l}\text { Min. Napoleão } \\
\text { Nunes Maia Filho }\end{array}$ & $\begin{array}{l}\text { dano e ambiental/ } \\
\text { responsabilidade } \\
\text { e civil e } \\
\text { ambiental }\end{array}$ \\
\hline $\begin{array}{l}\text { STJ REsp1.644.195- } \\
\text { SC }\end{array}$ & $\begin{array}{l}\text { j. } 2017 \\
\text { p. } 2017\end{array}$ & $2^{\mathrm{a}} \mathrm{T}$ & $\begin{array}{l}\text { Min. Herman } \\
\text { Benjamin }\end{array}$ & $\begin{array}{l}\text { dano e ambiente/ } \\
\text { dano e ambiental/ } \\
\text { degradação } \\
\text { e ambiente/ } \\
\text { degradação } \\
\text { e ambiental/ } \\
\text { responsabilidade } \\
\text { e civil e } \\
\text { ambiental }\end{array}$ \\
\hline $\begin{array}{l}\text { STJ REsp1.666.017- } \\
\text { RJ }\end{array}$ & $\begin{array}{l}\text { j. } 2017 \\
\text { p. } 2017\end{array}$ & $2^{\mathrm{a}} \mathrm{T}$ & $\begin{array}{l}\text { Min. Herman } \\
\text { Benjamin }\end{array}$ & $\begin{array}{l}\text { dano e ambiental/ } \\
\text { responsabilidade } \\
\text { e civil e } \\
\text { ambiental }\end{array}$ \\
\hline $\begin{array}{l}\text { STJ AgInt no REsp } \\
\text { 1355428-MS }\end{array}$ & $\begin{array}{l}\text { j. } 2017 \\
\text { p. } 2017\end{array}$ & $2^{\mathrm{a}} \mathrm{T}$ & $\begin{array}{l}\text { Min. Francisco } \\
\text { Falcão }\end{array}$ & $\begin{array}{l}\text { dano e ambiente/ } \\
\text { dano e ambiental }\end{array}$ \\
\hline
\end{tabular}




\begin{tabular}{|c|c|c|c|c|}
\hline $\begin{array}{l}\text { STJ AgInt nos EDcl } \\
\text { no AREsp 359.140- } \\
\text { MS }\end{array}$ & $\begin{array}{l}\text { j. } 2017 \\
\text { p. } 2017\end{array}$ & $2^{\mathrm{a}} \mathrm{T}$ & $\begin{array}{l}\text { Min. Assusete } \\
\text { Magalhães }\end{array}$ & $\begin{array}{l}\text { dano e ambiente/ } \\
\text { dano e ambiental }\end{array}$ \\
\hline $\begin{array}{l}\text { STJ AgInt no } \\
\text { AREsp 268.217-PE }\end{array}$ & $\begin{array}{l}\text { j. } 2017 \\
\text { p. } 2018\end{array}$ & $1^{\mathrm{a}} \mathrm{T}$. & Min. Gurgel de Faria & $\begin{array}{l}\text { dano e ambiente/ } \\
\text { dano e ambiental/ } \\
\text { responsabilidade } \\
\text { e civil e } \\
\text { ambiental }\end{array}$ \\
\hline $\begin{array}{l}\text { STJ AgInt no REsp } \\
\text { 1363943-SC }\end{array}$ & $\begin{array}{l}\text { j. } 2017 \\
\text { p. } 2017\end{array}$ & $1^{\mathrm{a}} \mathrm{T}$. & Min. Gurgel de Faria & $\begin{array}{l}\text { dano e ambiente/ } \\
\text { dano e ambiental }\end{array}$ \\
\hline $\begin{array}{l}\text { STJ AgRg no } \\
\text { AREsp 796.146-SP }\end{array}$ & $\begin{array}{l}\text { j. } 2017 \\
\text { p. } 2017\end{array}$ & $1^{\mathrm{a}} \mathrm{T}$. & $\begin{array}{l}\text { Min. Napoleão } \\
\text { Nunes Maia Filho }\end{array}$ & $\begin{array}{l}\text { dano e ambiente/ } \\
\text { dano e ambiental }\end{array}$ \\
\hline $\begin{array}{l}\text { STJ AgInt no REsp } \\
\text { 1391986-MS }\end{array}$ & $\begin{array}{l}\text { j. } 2017 \\
\text { p. } 2017\end{array}$ & $2^{\mathrm{a}} \mathrm{T}$ & $\begin{array}{l}\text { Min. Assusete } \\
\text { Magalhães }\end{array}$ & $\begin{array}{l}\text { dano e ambiente/ } \\
\text { dano e ambiental }\end{array}$ \\
\hline $\begin{array}{l}\text { STJ AgInt no } \\
\text { AREsp 1060669-SP }\end{array}$ & $\begin{array}{l}\text { j. } 2017 \\
\text { p. } 2017\end{array}$ & $2^{\mathrm{a}} \mathrm{T}$ & $\begin{array}{l}\text { Min. Herman } \\
\text { Benjamin }\end{array}$ & $\begin{array}{l}\text { responsabilidade } \\
\text { e civil e } \\
\text { ambiental }\end{array}$ \\
\hline $\begin{array}{l}\text { STJ AgRg no REsp } \\
\text { 1223499-SP }\end{array}$ & $\begin{array}{l}\text { j. } 2017 \\
\text { p. } 2017\end{array}$ & $1^{\mathrm{a}} \mathrm{T}$. & $\begin{array}{l}\text { Min. Napoleão } \\
\text { Nunes Maia Filho }\end{array}$ & $\begin{array}{l}\text { responsabilidade } \\
\text { e civil e } \\
\text { ambiental }\end{array}$ \\
\hline $\begin{array}{l}\text { STJ AgInt no REsp } \\
\text { 1382576-MS }\end{array}$ & $\begin{array}{l}\text { j. } 2017 \\
\text { p. } 2017\end{array}$ & $2^{\mathrm{a}} \mathrm{T}$. & $\begin{array}{l}\text { Min. Assusete } \\
\text { Magalhães }\end{array}$ & $\begin{array}{l}\text { responsabilidade } \\
\text { e civil e } \\
\text { ambiental }\end{array}$ \\
\hline $\begin{array}{l}\text { STJ AgInt no REsp } \\
\text { 1495757-MS }\end{array}$ & $\begin{array}{l}\text { j. } 2018 \\
\text { p. } 2018\end{array}$ & $2^{\mathrm{a}} \mathrm{T}$ & $\begin{array}{l}\text { Min. Francisco } \\
\text { Falcão }\end{array}$ & $\begin{array}{l}\text { dano e ambiente/ } \\
\text { dano e ambiental }\end{array}$ \\
\hline
\end{tabular}




\begin{tabular}{|l|l|l|l|l|}
\hline $\begin{array}{l}\text { STJ AgInt no } \\
\text { AREsp 1031389-SP }\end{array}$ & j. 2018 & $1^{\mathrm{a}} \mathrm{T}$. & $\begin{array}{l}\text { Min. Napoleão } \\
\text { punes Maia Filho }\end{array}$ & $\begin{array}{l}\text { dano e ambiental/ } \\
\text { degradação } \\
\text { e ambiental/ } \\
\text { degradação e } \\
\text { ambiente }\end{array}$ \\
\hline
\end{tabular}

\section{TABELA 2/ GRUPO 2: DANO AMBIENTAL}

EXTRAPATRIMONIAL E TEORIA DO RISCO INTEGRAL

\begin{tabular}{|c|c|c|c|c|}
\hline $\begin{array}{l}\text { Decisão (STJ/ } \\
\text { STF) }\end{array}$ & ANO & Turma & Relatoria & Palavras-chave \\
\hline $\begin{array}{l}\text { STJ } \\
\text { REsp442.586-SP } \\
\text { (Repetido no G6) }\end{array}$ & $\begin{array}{l}\text { j. } 2002 \\
\text { p. } 2003\end{array}$ & $1^{\mathrm{a}} \mathrm{T}$ & $\begin{array}{l}\text { Min. Luiz } \\
\text { Fux }\end{array}$ & $\begin{array}{l}\text { degradação e ambiente/ } \\
\text { degradação e ambiental/ dano } \\
\text { e ambiente/ dano e ambiental/ } \\
\text { responsabilidade e civil e } \\
\text { ambiental }\end{array}$ \\
\hline $\begin{array}{l}\text { STJ } \\
\text { REsp578.797-RS } \\
\text { (Repetido no G6) }\end{array}$ & $\begin{array}{l}\text { j. } 2004 \\
\text { p. } 2004\end{array}$ & $1^{\mathrm{a}} \mathrm{T}$ & $\begin{array}{l}\text { Min. Luiz } \\
\text { Fux }\end{array}$ & $\begin{array}{l}\text { degradação e ambiente/ } \\
\text { degradação e ambiental/ dano } \\
\text { e ambiente/ dano e ambiental/ } \\
\text { responsabilidade e civil e } \\
\text { ambiental }\end{array}$ \\
\hline $\begin{array}{l}\text { STJ } \\
\text { REsp598.281-MG }\end{array}$ & $\begin{array}{l}\text { j. } 2006 \\
\text { p. } 2006\end{array}$ & $1^{\mathrm{a}} \mathrm{T}$ & $\begin{array}{l}\text { Min. Luiz } \\
\text { Fux } \\
\text { Rel. p. } \\
\text { Acórdão: } \\
\text { Min. Teori } \\
\text { Albino } \\
\text { Zavascki }\end{array}$ & $\begin{array}{l}\text { degradação e ambiente/ } \\
\text { degradação e ambiental/ dano } \\
\text { e ambiente/ dano e ambiental/ } \\
\text { responsabilidade e civil e } \\
\text { ambiental }\end{array}$ \\
\hline $\begin{array}{l}\text { STJ } \\
\text { REsp1.120.117- } \\
\text { AC }\end{array}$ & $\begin{array}{l}\text { j. } 2009 \\
\text { p. } 2009\end{array}$ & $2^{\mathrm{a}} \mathrm{T}$ & $\begin{array}{l}\text { Min. Eliana } \\
\text { Calmon }\end{array}$ & $\begin{array}{l}\text { dano e ambiente/ dano e } \\
\text { ambiental/ responsabilidade e } \\
\text { civil e ambiental }\end{array}$ \\
\hline
\end{tabular}




\begin{tabular}{|c|c|c|c|c|}
\hline $\begin{array}{l}\text { STJ } \\
\text { REsp1.114.893- } \\
\text { MG } \\
\text { (Repetido no G4) }\end{array}$ & $\begin{array}{l}\text { j. } 2010 \\
\text { p. } 2012\end{array}$ & $2^{\mathrm{a}} \mathrm{T}$ & $\begin{array}{l}\text { Min. Herman } \\
\text { Benjamin }\end{array}$ & $\begin{array}{l}\text { degradação e ambiente/ } \\
\text { degradação e ambiental/ dano } \\
\text { e ambiente/ dano e ambiental/ } \\
\text { poluidor-pagador/ poluidor e } \\
\text { pagador }\end{array}$ \\
\hline $\begin{array}{l}\text { STJ } \\
\text { REsp1.145.083- } \\
\text { MG } \\
\text { (Repetido no G4) }\end{array}$ & $\begin{array}{l}\text { j. } 2011 \\
\text { p. } 2012\end{array}$ & $2^{\mathrm{a}} \mathrm{T}$ & $\begin{array}{l}\text { Min. Herman } \\
\text { Benjamin }\end{array}$ & $\begin{array}{l}\text { degradação e ambiente/ } \\
\text { degradação e ambiental/ dano } \\
\text { e ambiente/ dano e ambiental/ } \\
\text { poluidor-pagador/ poluidor e } \\
\text { pagador/ responsabilidade e } \\
\text { civil e ambiental }\end{array}$ \\
\hline $\begin{array}{l}\text { STJ AgRg no } \\
\text { AREsp89.444-PR }\end{array}$ & $\begin{array}{l}\text { j. } 2012 \\
\text { p. } 2012\end{array}$ & $3^{\mathrm{a}} \mathrm{T}$ & $\begin{array}{l}\text { Min. Paulo } \\
\text { de Tarso } \\
\text { Sanseverino }\end{array}$ & $\begin{array}{l}\text { dano e ambiente/ dano } \\
\text { e ambiental/ poluidor- } \\
\text { pagador/ poluidor e pagador/ } \\
\text { responsabilidade e civil e } \\
\text { ambiental }\end{array}$ \\
\hline $\begin{array}{l}\text { STJ AgRg no } \\
\text { AREsp119.624- } \\
\text { PR }\end{array}$ & $\begin{array}{l}\text { j. } 2012 \\
\text { p. } 2012\end{array}$ & $3^{\mathrm{a}} \mathrm{T}$ & $\begin{array}{l}\text { Min. Ricardo } \\
\text { Villas Bôas } \\
\text { Cuevas }\end{array}$ & $\begin{array}{l}\text { dano e ambiente/ dano e } \\
\text { ambiental/ poluidor e pagador }\end{array}$ \\
\hline $\begin{array}{l}\text { STJ AgRg no } \\
\text { AREsp137.851- } \\
\text { PR }\end{array}$ & $\begin{array}{l}\text { j. } 2012 \\
\text { p. } 2012\end{array}$ & $3^{\mathrm{a}} \mathrm{T}$ & $\begin{array}{l}\text { Min. Sidnei } \\
\text { Beneti }\end{array}$ & $\begin{array}{l}\text { dano e ambiente/ dano e } \\
\text { ambiental/ responsabilidade e } \\
\text { civil e ambiental }\end{array}$ \\
\hline $\begin{array}{l}\text { STJ AgRg no } \\
\text { AREsp249.208- } \\
\text { PR }\end{array}$ & $\begin{array}{l}\text { j. } 2012 \\
\text { p. } 2013\end{array}$ & $4^{\mathrm{a}} \mathrm{T}$ & $\begin{array}{l}\text { Min. Marco } \\
\text { Buzzi }\end{array}$ & $\begin{array}{l}\text { dano e ambiente/ dano e } \\
\text { ambiental }\end{array}$ \\
\hline $\begin{array}{l}\text { STJ AgRg no } \\
\text { AREsp258.212- } \\
\text { PR }\end{array}$ & $\begin{array}{l}\text { j. } 2012 \\
\text { p. } 2013\end{array}$ & $3^{\mathrm{a}} \mathrm{T}$ & $\begin{array}{l}\text { Min. Sidnei } \\
\text { Beneti }\end{array}$ & dano e ambiental \\
\hline $\begin{array}{l}\text { STJ } \\
\text { REsp1.114.398- } \\
\text { PR }\end{array}$ & $\begin{array}{l}\text { j. } 2012 \\
\text { p. } 2012\end{array}$ & $2^{\mathrm{a}} \mathrm{S}$ & $\begin{array}{l}\text { Min. Sidnei } \\
\text { Beneti }\end{array}$ & $\begin{array}{l}\text { dano e ambiente/ dano } \\
\text { e ambiental/ poluidor- } \\
\text { pagador/ poluidor e pagador/ } \\
\text { responsabilidade e civil e } \\
\text { ambiental }\end{array}$ \\
\hline
\end{tabular}




\begin{tabular}{|c|c|c|c|c|}
\hline $\begin{array}{l}\text { STJ } \\
\text { REsp119.8727- } \\
\text { MG } \\
\text { (Repetido no G4) }\end{array}$ & $\begin{array}{l}\text { j. } 2012 \\
\text { p. } 2013\end{array}$ & $2^{\mathrm{a}} \mathrm{T}$ & $\begin{array}{l}\text { Min. Herman } \\
\text { Benjamin }\end{array}$ & $\begin{array}{l}\text { degradação e ambiente/ } \\
\text { degradação e ambiental/ dano } \\
\text { e ambiente/ dano e ambiental/ } \\
\text { internalização e ambiental/ } \\
\text { poluidor-pagador/ poluidor } \\
\text { e pagador/ responsabilidade } \\
\text { e civil e ambiental/ usuário e } \\
\text { pagador }\end{array}$ \\
\hline $\begin{array}{l}\text { STJ } \\
\text { REsp134.6430- } \\
\text { PR }\end{array}$ & $\begin{array}{l}\text { j. } 2012 \\
\text { p. } 2012\end{array}$ & $4^{\mathrm{a}} \mathrm{T}$ & $\begin{array}{l}\text { Min. Luis } \\
\text { Felipe } \\
\text { Salomão }\end{array}$ & $\begin{array}{l}\text { dano e ambiente/ dano } \\
\text { e ambiental/ poluidor- } \\
\text { pagador/ poluidor e pagador/ } \\
\text { responsabilidade e civil e } \\
\text { ambiental }\end{array}$ \\
\hline $\begin{array}{l}\text { STJ AgRg no } \\
\text { AREsp71.324-PR }\end{array}$ & $\begin{array}{l}\text { j. } 2013 \\
\text { p. } 2013\end{array}$ & $4^{\mathrm{a}} \mathrm{T}$ & $\begin{array}{l}\text { Min. Antonio } \\
\text { Carlos } \\
\text { Ferreira }\end{array}$ & $\begin{array}{l}\text { dano e ambiental/ } \\
\text { responsabilidade e civil e } \\
\text { ambiental }\end{array}$ \\
\hline $\begin{array}{l}\text { STJ AgRg no } \\
\text { AREsp92.652-PR }\end{array}$ & $\begin{array}{l}\text { j. } 2013 \\
\text { p. } 2013\end{array}$ & $4^{\mathrm{a}} \mathrm{T}$ & $\begin{array}{l}\text { Min. Antonio } \\
\text { Carlos } \\
\text { Ferreira }\end{array}$ & $\begin{array}{l}\text { dano e ambiente/ dano e } \\
\text { ambiental/ responsabilidade e } \\
\text { civil e ambiental }\end{array}$ \\
\hline $\begin{array}{l}\text { STJ AgRg no } \\
\text { AREsp99.092-PR }\end{array}$ & $\begin{array}{l}\text { j. } 2013 \\
\text { p. } 2013\end{array}$ & $3^{\mathrm{a}} \mathrm{T}$ & $\begin{array}{l}\text { Min. Paulo } \\
\text { de Tarso } \\
\text { Sanseverino }\end{array}$ & $\begin{array}{l}\text { dano e ambiente/ dano e } \\
\text { ambiental/ responsabilidade e } \\
\text { civil e ambiental }\end{array}$ \\
\hline $\begin{array}{l}\text { STJ AgRg no } \\
\text { AREsp238.427- } \\
\text { PR }\end{array}$ & $\begin{array}{l}\text { j. } 2013 \\
\text { p. } 2013\end{array}$ & $3^{\mathrm{a}} \mathrm{T}$ & $\begin{array}{l}\text { Min. Ricardo } \\
\text { Villas Bôas } \\
\text { Cuevas }\end{array}$ & $\begin{array}{l}\text { dano e ambienta/ poluidor- } \\
\text { pagador/ poluidor e pagador/ } \\
\text { responsabilidade e civil e } \\
\text { ambiental }\end{array}$ \\
\hline $\begin{array}{l}\text { STJ AgRg no } \\
\text { AREsp254.149- } \\
\text { PR }\end{array}$ & $\begin{array}{l}\text { j. } 2013 \\
\text { p. } 2013\end{array}$ & $3^{\mathrm{a}} \mathrm{T}$ & $\begin{array}{l}\text { Min. Sidnei } \\
\text { Beneti }\end{array}$ & dano e ambiental \\
\hline $\begin{array}{l}\text { STJ AgRg no } \\
\text { AREsp256.505- } \\
\text { PR }\end{array}$ & $\begin{array}{l}\text { j. } 2013 \\
\text { p. } 2013\end{array}$ & $3^{\mathrm{a}} \mathrm{T}$ & $\begin{array}{l}\text { Min. Sidnei } \\
\text { Beneti }\end{array}$ & $\begin{array}{l}\text { dano e ambiente/ dano e } \\
\text { ambiental }\end{array}$ \\
\hline $\begin{array}{l}\text { STJ AgRg no } \\
\text { AREsp258.263- } \\
\text { PR }\end{array}$ & $\begin{array}{l}\text { j. } 2013 \\
\text { p. } 2013\end{array}$ & $4^{\mathrm{a}} \mathrm{T}$. & $\begin{array}{l}\text { Min. Antonio } \\
\text { Carlos } \\
\text { Ferreira }\end{array}$ & $\begin{array}{l}\text { dano e ambiente/ dano e } \\
\text { ambiental/responsabilidade e } \\
\text { civil e ambiental }\end{array}$ \\
\hline
\end{tabular}




\begin{tabular}{|c|c|c|c|c|}
\hline $\begin{array}{l}\text { STJ AgRg no } \\
\text { AREsp273.058- } \\
\text { PR }\end{array}$ & $\begin{array}{l}\text { j. } 2013 \\
\text { p. } 2013\end{array}$ & $4^{\mathrm{a}} \mathrm{T}$ & $\begin{array}{l}\text { Min. Antonio } \\
\text { Carlos } \\
\text { Ferreira }\end{array}$ & $\begin{array}{l}\text { dano e ambiente/ dano e } \\
\text { ambiental/ responsabilidade e } \\
\text { civil e ambiental }\end{array}$ \\
\hline $\begin{array}{l}\text { STJ AgRg no } \\
\text { AREsp281.177- } \\
\text { PR }\end{array}$ & $\begin{array}{l}\text { j. } 2013 \\
\text { p. } 2013\end{array}$ & $4^{\mathrm{a}} \mathrm{T}$ & $\begin{array}{l}\text { Min. Raul } \\
\text { Araújo }\end{array}$ & $\begin{array}{l}\text { dano e ambiental/ } \\
\text { responsabilidade e civil e } \\
\text { ambiental }\end{array}$ \\
\hline $\begin{array}{l}\text { STJ } \\
\text { REsp1.269.494- } \\
\text { MG } \\
\text { (Repetido no G4) }\end{array}$ & $\begin{array}{l}\text { j. } 2013 \\
\text { p. } 2013\end{array}$ & $2^{\mathrm{a}} \mathrm{T}$ & $\begin{array}{l}\text { Min. Eliana } \\
\text { Calmon }\end{array}$ & $\begin{array}{l}\text { dano e ambiente/ dano e } \\
\text { ambiental }\end{array}$ \\
\hline $\begin{array}{l}\text { STJ } \\
\text { REsp1.346.489- } \\
\text { RS } \\
\text { (Repetido no G1) }\end{array}$ & $\begin{array}{l}\text { j. } 2013 \\
\text { p. } 2013\end{array}$ & $3^{\mathrm{a}} \mathrm{T}$ & $\begin{array}{l}\text { Min. Ricardo } \\
\text { Villas Bôas } \\
\text { Cuevas }\end{array}$ & $\begin{array}{l}\text { dano e ambiente/ dano e } \\
\text { ambiental/ responsabilidade e } \\
\text { civil e ambiental }\end{array}$ \\
\hline $\begin{array}{l}\text { STJ } \\
\text { REsp1.367.923- } \\
\text { RJ }\end{array}$ & $\begin{array}{l}\text { j. } 2013 \\
\text { p. } 2013\end{array}$ & $2^{\mathrm{a}} \mathrm{T}$ & $\begin{array}{l}\text { Min. } \\
\text { Humberto } \\
\text { Martins }\end{array}$ & $\begin{array}{l}\text { degradação e ambiente/ } \\
\text { degradação e ambiental/ dano e } \\
\text { ambiente/ dano e ambiental }\end{array}$ \\
\hline $\begin{array}{l}\text { STJ } \\
\text { REsp1.374.342- } \\
\text { MG }\end{array}$ & $\begin{array}{l}\text { j. } 2013 \\
\text { p. } 2013\end{array}$ & $4^{\mathrm{a}} \mathrm{T}$ & $\begin{array}{l}\text { Min. Luis } \\
\text { Felipe } \\
\text { Salomão }\end{array}$ & $\begin{array}{l}\text { dano e ambiente/ dano e } \\
\text { ambiental/ responsabilidade e } \\
\text { civil e ambiental }\end{array}$ \\
\hline $\begin{array}{l}\text { STJ EDcl no } \\
\text { REsp1.346.430- } \\
\text { PR }\end{array}$ & $\begin{array}{l}\text { j. } 2013 \\
\text { p. } 2013\end{array}$ & $4^{\mathrm{a}} \mathrm{T}$ & $\begin{array}{l}\text { Min. Luis } \\
\text { Felipe } \\
\text { Salomão }\end{array}$ & $\begin{array}{l}\text { dano e ambiente/ dano e } \\
\text { ambiental/ responsabilidade e } \\
\text { civil e ambiental }\end{array}$ \\
\hline $\begin{array}{l}\text { STJ EDcl no } \\
\text { REsp1.373.788- } \\
\text { SP }\end{array}$ & $\begin{array}{l}\text { j. } 2014 \\
\text { p. } 2014\end{array}$ & $3^{\mathrm{a}} \mathrm{T}$ & $\begin{array}{l}\text { Min. Paulo } \\
\text { de Tarso } \\
\text { Sanseverino }\end{array}$ & $\begin{array}{l}\text { dano e ambiente/ dano e } \\
\text { ambiental/ responsabilidade e } \\
\text { civil e ambiental }\end{array}$ \\
\hline $\begin{array}{l}\text { STJ } \\
\text { REsp1.175.907- } \\
\text { MG }\end{array}$ & $\begin{array}{l}\text { j. } 2014 \\
\text { p. } 2014\end{array}$ & $4^{\mathrm{a}} \mathrm{T}$ & $\begin{array}{l}\text { Min. Luis } \\
\text { Felipe } \\
\text { Salomão }\end{array}$ & $\begin{array}{l}\text { dano e ambiente/ dano e } \\
\text { ambiental/ responsabilidade e } \\
\text { civil e ambiental }\end{array}$ \\
\hline
\end{tabular}




\begin{tabular}{|c|c|c|c|c|}
\hline $\begin{array}{l}\text { STJ } \\
\text { REsp1.354.536- } \\
\text { SE }\end{array}$ & $\begin{array}{l}\text { j. } 2014 \\
\text { p. } 2014\end{array}$ & $2^{\mathrm{a}} \mathrm{S}$ & $\begin{array}{l}\text { Min. Luis } \\
\text { Felipe } \\
\text { Salomão }\end{array}$ & $\begin{array}{l}\text { dano e ambiente/ dano } \\
\text { e ambienta/ poluidor- } \\
\text { pagador/ poluidor e pagador/ } \\
\text { responsabilidade e civil e } \\
\text { ambiental }\end{array}$ \\
\hline $\begin{array}{l}\text { STJ } \\
\text { REsp1.374.284- } \\
\text { MG }\end{array}$ & $\begin{array}{l}\text { j. } 2014 \\
\text { p. } 2014\end{array}$ & $2^{\mathrm{a}} \mathrm{S}$ & $\begin{array}{l}\text { Min. Luis } \\
\text { Felipe } \\
\text { Salomão }\end{array}$ & $\begin{array}{l}\text { dano e ambiente/ dano e } \\
\text { ambiental/ responsabilidade e } \\
\text { civil e ambiental }\end{array}$ \\
\hline $\begin{array}{l}\text { STJ } \\
\text { REsp1.381.211- } \\
\text { TO }\end{array}$ & $\begin{array}{l}\text { j. } 2014 \\
\text { p. } 2014\end{array}$ & $4^{\mathrm{a}} \mathrm{T}$ & $\begin{array}{l}\text { Min. Marco } \\
\text { Buzzi }\end{array}$ & $\begin{array}{l}\text { dano e ambiente/ dano e } \\
\text { ambiental/ responsabilidade e } \\
\text { civil e ambiental }\end{array}$ \\
\hline $\begin{array}{l}\text { STJ AgRg no } \\
\text { AREsp117.202- } \\
\text { PR }\end{array}$ & $\begin{array}{l}\text { j. } 2015 \\
\text { p. } 2015\end{array}$ & $4^{\mathrm{a}} \mathrm{T}$ & $\begin{array}{l}\text { Min. Antonio } \\
\text { Carlos } \\
\text { Ferreira }\end{array}$ & $\begin{array}{l}\text { degradação e ambiente/ } \\
\text { degradação e ambiental/ } \\
\text { dano e ambiente/ dano e } \\
\text { ambiental/ poluidor e pagador/ } \\
\text { responsabilidade e civil e } \\
\text { ambiental }\end{array}$ \\
\hline $\begin{array}{l}\text { STJ AgRg no } \\
\text { AREsp232.494- } \\
\text { PR }\end{array}$ & $\begin{array}{l}\text { j. } 2015 \\
\text { p. } 2015\end{array}$ & $4^{\mathrm{a}} \mathrm{T}$ & $\begin{array}{l}\text { Min. Marco } \\
\text { Buzzi }\end{array}$ & $\begin{array}{l}\text { dano e ambiente/ dano e } \\
\text { ambiental/ responsabilidade e } \\
\text { civil e ambiental }\end{array}$ \\
\hline $\begin{array}{l}\text { STJ AgRg no } \\
\text { AREsp820.193- } \\
\text { MA }\end{array}$ & $\begin{array}{l}\text { j. } 2017 \\
\text { p. } 2017\end{array}$ & $3^{\mathrm{a}} \mathrm{T}$ & $\begin{array}{l}\text { Min. Moura } \\
\text { Ribeiro }\end{array}$ & $\begin{array}{l}\text { dano e ambiental/ } \\
\text { responsabilidade e civil e } \\
\text { ambiental }\end{array}$ \\
\hline $\begin{array}{l}\text { SRJ AgInt no } \\
\text { AREsp 1100789- } \\
\text { SP }\end{array}$ & $\begin{array}{l}\text { j. } 2017 \\
\text { p. } 2017\end{array}$ & $2^{\mathrm{a}} \mathrm{T}$ & $\begin{array}{l}\text { Min. Assusete } \\
\text { Magalhães }\end{array}$ & $\begin{array}{l}\text { Poluidor e pagador/ poluidor- } \\
\text { pagador/ dano e ambiente/ dano } \\
\text { e ambiental/ responsabilidade e } \\
\text { civil e ambiental/ degradação e } \\
\text { ambiental }\end{array}$ \\
\hline $\begin{array}{l}\text { STJ REsp } \\
\text { 1669185-RS } \\
\text { (Repetido no G4) }\end{array}$ & $\begin{array}{l}\text { j. } 2017 \\
\text { p. } 2017\end{array}$ & $2^{\mathrm{a}} \mathrm{T}$ & $\begin{array}{l}\text { Min. Herman } \\
\text { Benjamin }\end{array}$ & $\begin{array}{l}\text { Poluidor e pagador/ poluidor- } \\
\text { pagador/ usuário e pagador/ } \\
\text { usuário-pagador/ dano e } \\
\text { ambiente/ dano e ambiental }\end{array}$ \\
\hline
\end{tabular}




\begin{tabular}{|l|l|l|l|l|}
\hline $\begin{array}{l}\text { STJ AgInt no } \\
\text { AREsp 931.188- } \\
\text { PR }\end{array}$ & $\begin{array}{l}\text { j. } 2017 \\
\text { p. } 2018\end{array}$ & $3^{\text {a T. }}$ & $\begin{array}{l}\text { Min. Marco } \\
\text { Aurélio } \\
\text { Bellizze }\end{array}$ & dano e ambiente \\
\hline $\begin{array}{l}\text { STJ REsp } \\
1602106 / \text { PR }\end{array}$ & $\begin{array}{l}\text { j. } 2017 \\
\text { p. } 2017\end{array}$ & $\begin{array}{l}2^{\text {a }} \text { Seção } \\
\text { Recurso } \\
\text { repetitivo }\end{array}$ & $\begin{array}{l}\text { Min. Ricardo } \\
\text { Villas Bôas } \\
\text { Cueva }\end{array}$ & dano e ambiente \\
\hline $\begin{array}{l}\text { STJ AgRg no } \\
\text { AREsp 150.735- } \\
\text { PR }\end{array}$ & $\begin{array}{l}\text { p. } 2018 \\
\text { p. } 2018\end{array}$ & $4^{\text {a T. }}$ & $\begin{array}{l}\text { Min. Marco } \\
\text { Buzzi }\end{array}$ & $\begin{array}{l}\text { dano e ambiente/ dano e } \\
\text { ambiental }\end{array}$ \\
\hline
\end{tabular}

\begin{tabular}{|c|c|c|c|c|}
\hline \multicolumn{5}{|c|}{$\begin{array}{l}\text { TABELA 3/ GRUPO 3: RESPONSABILIDADE CIVIL AMBIENTAL DO ESTADO POR } \\
\text { OMISSÃO }\end{array}$} \\
\hline Decisão (STJ/STF) & ANO & Turma & Relatoria & Palavras-chave \\
\hline STJ REsp28.222-SP & $\begin{array}{l}\text { j. } 2000 \\
\text { p. } 2001\end{array}$ & $2^{\mathrm{a}} \mathrm{T}$ & $\begin{array}{l}\text { Min. Eliana } \\
\text { Calmon } \\
\text { Rel. p. o acórdão: } \\
\text { Min. Nancy } \\
\text { Andrighi }\end{array}$ & $\begin{array}{l}\text { dano e ambiente/ dano e } \\
\text { ambiental/responsabilidade } \\
\text { e civil e ambiental }\end{array}$ \\
\hline $\begin{array}{l}\text { STJ REsp333.056- } \\
\text { SP }\end{array}$ & $\begin{array}{l}\text { j. } 2005 \\
\text { p. } 2006\end{array}$ & $2^{\mathrm{a}} \mathrm{T}$ & $\begin{array}{l}\text { Min. Castro } \\
\text { Meira }\end{array}$ & $\begin{array}{l}\text { responsabilidade e civil e } \\
\text { ambiental }\end{array}$ \\
\hline $\begin{array}{l}\text { STJ REsp604.725- } \\
\text { PR }\end{array}$ & $\begin{array}{l}\text { j. } 2005 \\
\text { p. } 2005\end{array}$ & $2^{\mathrm{a}} \mathrm{T}$ & $\begin{array}{l}\text { Min. Castro } \\
\text { Meira }\end{array}$ & $\begin{array}{l}\text { dano e ambiente/ dano e } \\
\text { ambiental/responsabilidade } \\
\text { e civil e ambiental }\end{array}$ \\
\hline $\begin{array}{l}\text { STJ AgRg no Ag } \\
822.764-\mathrm{MG}\end{array}$ & $\begin{array}{l}\text { j. } 2007 \\
\text { p. } 2007\end{array}$ & $1^{\mathrm{a}} \mathrm{T}$ & $\begin{array}{l}\text { Min. José } \\
\text { Delgado }\end{array}$ & $\begin{array}{l}\text { dano e ambiente/ dano e } \\
\text { ambiental/responsabilidade } \\
\text { e civil e ambiental }\end{array}$ \\
\hline
\end{tabular}




\begin{tabular}{|c|c|c|c|c|}
\hline $\begin{array}{l}\text { STJ REsp647.493- } \\
\text { SC }\end{array}$ & $\begin{array}{l}\text { j. } 2007 \\
\text { p. } 2007\end{array}$ & $2^{\mathrm{a}} \mathrm{T}$ & $\begin{array}{l}\text { Min. João Otávio } \\
\text { Noronha }\end{array}$ & $\begin{array}{l}\text { custos e ambiente/ custos } \\
\text { e ambientais/ degradação } \\
\text { e ambiente/ degradação } \\
\text { e ambiental/ dano e } \\
\text { ambiente/ dano e ambiental/ } \\
\text { responsabilidade e civil e } \\
\text { ambiental }\end{array}$ \\
\hline $\begin{array}{l}\text { STJ AgRg no Ag } \\
973.577-\text { SP }\end{array}$ & $\begin{array}{l}\text { j. } 2008 \\
\text { p. } 2008\end{array}$ & $2^{\mathrm{a}} \mathrm{T}$ & $\begin{array}{l}\text { Min. Mauro } \\
\text { Campbell }\end{array}$ & $\begin{array}{l}\text { dano e ambiente/ dano e } \\
\text { ambiental/ responsabilidade } \mathrm{e} \\
\text { civil e ambiental }\end{array}$ \\
\hline $\begin{array}{l}\text { STJREsp1.071.741- } \\
\text { SP }\end{array}$ & $\begin{array}{l}\text { j. } 2009 \\
\text { p. } 2011\end{array}$ & $2^{\mathrm{a}} \mathrm{T}$ & $\begin{array}{l}\text { Min. Herman } \\
\text { Benjamin }\end{array}$ & $\begin{array}{l}\text { degradação e ambiente/ } \\
\text { degradação e ambiental/ } \\
\text { dano e ambiente/ dano e } \\
\text { ambiental/ externalidade/ } \\
\text { externalidade e ambiental } \\
\text { e negativa/ internalização e } \\
\text { ambiente/internalização e } \\
\text { ambiental/ poluidor-pagador/ } \\
\text { responsabilidade e civil e } \\
\text { ambiental }\end{array}$ \\
\hline $\begin{array}{l}\text { STJ REsp1.113.789- } \\
\text { SP }\end{array}$ & $\begin{array}{l}\text { j. } 2009 \\
\text { p. } 2009\end{array}$ & $2^{\mathrm{a}} \mathrm{T}$ & $\begin{array}{l}\text { Min. } \quad \text { Castro } \\
\text { Meira }\end{array}$ & $\begin{array}{l}\text { dano e ambiente/ dano e } \\
\text { ambiental/ responsabilidade } \mathrm{e} \\
\text { civil e ambiental }\end{array}$ \\
\hline $\begin{array}{l}\text { STJREsp1.195.421- } \\
\text { RJ } \\
\text { (Repetido no G4) }\end{array}$ & $\begin{array}{l}\text { j. } 2010 \\
\text { p. } 2010\end{array}$ & $2^{\mathrm{a}} \mathrm{T}$ & $\begin{array}{l}\text { Min. Mauro } \\
\text { Campbell }\end{array}$ & $\begin{array}{l}\text { dano e ambiental/ } \\
\text { responsabilidade e civil e } \\
\text { ambiental }\end{array}$ \\
\hline $\begin{array}{l}\text { STJ AgRg no } \\
\text { REsp1.001.780-PR } \\
\text { (Repetido no G1) }\end{array}$ & $\begin{array}{l}\text { j. } 2011 \\
\text { p. } 2011\end{array}$ & $1^{\mathrm{a}} \mathrm{T}$. & $\begin{array}{l}\text { Min. Teori Albino } \\
\text { Zavascki }\end{array}$ & $\begin{array}{l}\text { degradação e ambiente/ } \\
\text { degradação e ambiental/ dano } \\
\text { e ambiente/ dano e ambiental/ } \\
\text { responsabilidade e civil e } \\
\text { ambiental }\end{array}$ \\
\hline $\begin{array}{l}\text { STJREsp1.236.863- } \\
\text { ES }\end{array}$ & $\begin{array}{l}\text { j. } 2011 \\
\text { p. } 2012\end{array}$ & $2^{\mathrm{a}} \mathrm{T}$ & $\begin{array}{l}\text { Min. Herman } \\
\text { Benjamin }\end{array}$ & dano e ambiental \\
\hline
\end{tabular}




\begin{tabular}{|c|c|c|c|c|}
\hline $\begin{array}{l}\text { STJREsp1.266.920- } \\
\text { PR }\end{array}$ & $\begin{array}{l}\text { j. } 2012 \\
\text { p. } 2012\end{array}$ & $2^{\mathrm{a}} \mathrm{T}$. & $\begin{array}{l}\text { Min. Mauro } \\
\text { Campbell }\end{array}$ & $\begin{array}{l}\text { dano e ambiente/ dano e } \\
\text { ambiental }\end{array}$ \\
\hline $\begin{array}{l}\text { STJREsp1.376.199- } \\
\text { SP }\end{array}$ & $\begin{array}{l}\text { j. } 2014 \\
\text { p. } 2016\end{array}$ & $2^{\mathrm{a}} \mathrm{T}$ & $\begin{array}{l}\text { Min. Herman } \\
\text { Benjamin }\end{array}$ & $\begin{array}{l}\text { degradação e ambiente/ } \\
\text { degradação e ambiental/ dano } \\
\text { e ambiente/ dano e ambiental/ } \\
\text { responsabilidade e civil e } \\
\text { ambiental }\end{array}$ \\
\hline $\begin{array}{l}\text { STJ AgRg no } \\
\text { REsp1.379.030-RJ }\end{array}$ & $\begin{array}{l}\text { j. } 2014 \\
\text { p. } 2014\end{array}$ & $2^{\mathrm{a}} \mathrm{T}$ & $\begin{array}{l}\text { Min. Mauro } \\
\text { Campbell }\end{array}$ & dano e ambiental \\
\hline $\begin{array}{l}\text { STJ AgRg no } \\
\text { AREsp1.218.902- } \\
\text { SC }\end{array}$ & $\begin{array}{l}\text { j. } 2015 \\
\text { p. } 2015\end{array}$ & $1^{\mathrm{a}} \mathrm{T}$. & $\begin{array}{lr}\text { Min. } & \text { Napoleão } \\
\text { Nunes } & \text { Maia } \\
\text { Filho } & \end{array}$ & $\begin{array}{l}\text { responsabilidade e civil e } \\
\text { ambiental }\end{array}$ \\
\hline $\begin{array}{l}\text { STJ AgRg no } \\
\text { REsp1.497.096-RJ }\end{array}$ & $\begin{array}{l}\text { j. } 2015 \\
\text { p. } 2015\end{array}$ & $2^{\mathrm{a}} \mathrm{T}$ & $\begin{array}{l}\text { Min. Mauro } \\
\text { Campbell }\end{array}$ & $\begin{array}{l}\text { degradação e ambiental/ dano } \\
\text { e ambiental }\end{array}$ \\
\hline $\begin{array}{l}\text { STJREsp1.581.124- } \\
\text { SP }\end{array}$ & $\begin{array}{l}\text { j. } 2016 \\
\text { p. } 2016\end{array}$ & $2^{\mathrm{a}} \mathrm{T}$ & $\begin{array}{l}\text { Min. Humberto } \\
\text { Martins }\end{array}$ & $\begin{array}{l}\text { dano e ambiente/ dano e } \\
\text { ambiental/responsabilidade e } \\
\text { civil e ambiental }\end{array}$ \\
\hline $\begin{array}{l}\text { STJ REsp 1666027/ } \\
\text { SP }\end{array}$ & $\begin{array}{l}\text { j. } 2017 \\
\text { p. } 2018\end{array}$ & $2^{\mathrm{a}} \mathrm{T}$ & $\begin{array}{l}\text { Min. Herman } \\
\text { Benjamin }\end{array}$ & $\begin{array}{l}\text { dano e ambiente/ dano e } \\
\text { ambiental/responsabilidade e } \\
\text { civil e ambiental/ degradação } \\
\text { e ambiente }\end{array}$ \\
\hline $\begin{array}{l}\text { STJ REsp 1693624/ } \\
\text { SP }\end{array}$ & $\begin{array}{l}\text { j. } 2017 \\
\text { p. } 2017\end{array}$ & $2^{\mathrm{a}} \mathrm{T}$ & $\begin{array}{l}\text { Min. Herman } \\
\text { Benjamin }\end{array}$ & $\begin{array}{l}\text { dano e ambiente/dano e } \\
\text { ambiental }\end{array}$ \\
\hline
\end{tabular}

\section{TABELA 4/ GRUPO 4: POSSIBILIDADE DE CUMULAÇÃO DE OBRIGAÇÃO DE}

FAZER E DE PAGAR

\begin{tabular}{|l|l|l|l|l|}
\hline Decisão (STJ/STF) & ANO & Turma & Relatoria & Palavras-chave \\
\hline $\begin{array}{l}\text { STJ REsp 346.227- } \\
\text { SP }\end{array}$ & $\begin{array}{l}\text { j. } 2001 \\
\text { p. } 2002\end{array}$ & $1^{\text {a }}$ T. & Min. Garcia & dano e ambiente \\
(Repetido no G1) & & & Vieira & \\
\hline
\end{tabular}




\begin{tabular}{|c|c|c|c|c|}
\hline $\begin{array}{l}\text { STJ REsp 605.323- } \\
\text { MG }\end{array}$ & $\begin{array}{l}\text { j. } 2005 \\
\text { p. } 2005\end{array}$ & $1^{\mathrm{a}} \mathrm{T}$ & $\begin{array}{l}\text { Min. José } \\
\text { Delgado }\end{array}$ & $\begin{array}{l}\text { dano e ambiente/dano } \\
\text { e ambiental/poluidor- } \\
\text { pagador/ }\end{array}$ \\
\hline $\begin{array}{l}\text { STJ REsp 625.249- } \\
\text { PR }\end{array}$ & $\begin{array}{l}\text { j. } 2006 \\
\text { p. } 2006\end{array}$ & $1^{\mathrm{a}} \mathrm{T}$ & Min. Luiz Fux & $\begin{array}{l}\text { dano e ambiente/dano e } \\
\text { ambiental/poluidor-pagador }\end{array}$ \\
\hline $\begin{array}{l}\text { STJ AgRg no REsp } \\
\text { 1.170.532-MG }\end{array}$ & $\begin{array}{l}\text { j. } 2010 \\
\text { p. } 2010\end{array}$ & $1^{\mathrm{a}} \mathrm{T}$ & $\begin{array}{l}\text { Min. Hamilton } \\
\text { Carvalhido }\end{array}$ & $\begin{array}{l}\text { dano e ambiente/dano e } \\
\text { ambiental }\end{array}$ \\
\hline $\begin{array}{l}\text { STJ REsp 880.172- } \\
\text { SP }\end{array}$ & $\begin{array}{l}\text { j. } 2010 \\
\text { p. } 2010\end{array}$ & $2^{\mathrm{a}} \mathrm{T}$ & $\begin{array}{l}\text { Min. Mauro } \\
\text { Campbell }\end{array}$ & $\begin{array}{l}\text { poluidor e pagador } \\
\text { / poluidor-pagador / } \\
\text { responsabilidade e civil e } \\
\text { ambiental / dano e ambiente }\end{array}$ \\
\hline $\begin{array}{l}\text { STJ REsp } \\
\text { 1.114.893-MG } \\
\text { (Repetido no G2) }\end{array}$ & $\begin{array}{l}\text { j. } 2010 \\
\text { p. } 2012\end{array}$ & $2^{\mathrm{a}} \mathrm{T}$ & $\begin{array}{l}\text { Min. Herman } \\
\text { Benjamin }\end{array}$ & $\begin{array}{l}\text { degradação e ambiente / } \\
\text { degradação e ambiental / } \\
\text { dano e ambiente/ poluidor } \\
\text { e pagador / poluidor- } \\
\text { pagador / }\end{array}$ \\
\hline $\begin{array}{l}\text { STJ REsp } \\
1.165 .281-\mathrm{MG}\end{array}$ & $\begin{array}{l}\text { j. } 2010 \\
\text { p. } 2010\end{array}$ & $2^{\mathrm{a}} \mathrm{T}$ & $\begin{array}{l}\text { Min. Eliana } \\
\text { Calmon }\end{array}$ & $\begin{array}{l}\text { responsabilidade e civil e } \\
\text { ambiental }\end{array}$ \\
\hline $\begin{array}{l}\text { STJ REsp } \\
\text { 1.173.272-MG }\end{array}$ & $\begin{array}{l}\text { j. } 2010 \\
\text { p. } 2011\end{array}$ & $3^{\mathrm{a}} \mathrm{T}$ & $\begin{array}{l}\text { Min. Nancy } \\
\text { Andrighi }\end{array}$ & $\begin{array}{l}\text { dano e ambiental/ } \\
\text { responsabilidade e civil e } \\
\text { ambiental }\end{array}$ \\
\hline $\begin{array}{l}\text { STJ REsp } \\
\text { 1.178.294-MG }\end{array}$ & $\begin{array}{l}\text { j. } 2010 \\
\text { p. } 2010\end{array}$ & $2^{\mathrm{a}} \mathrm{T}$ & $\begin{array}{l}\text { Min. Mauro } \\
\text { Campbell }\end{array}$ & $\begin{array}{l}\text { poluidor-pagador/ poluidor } \\
\text { e pagador }\end{array}$ \\
\hline $\begin{array}{l}\text { STJ REsp } \\
1.180 .078-\mathrm{MG}\end{array}$ & $\begin{array}{l}\text { j. } 2010 \\
\text { p. } 2012\end{array}$ & $2^{\mathrm{a}} \mathrm{T}$ & $\begin{array}{l}\text { Min. Herman } \\
\text { Benjamin }\end{array}$ & $\begin{array}{l}\text { degradação e ambiente / } \\
\text { degradação e ambiental/ } \\
\text { dano e ambiente/ poluidor e } \\
\text { pagador / poluidor-pagador } \\
\text { / responsabilidade e civil e } \\
\text { ambiental }\end{array}$ \\
\hline
\end{tabular}




\begin{tabular}{|c|c|c|c|c|}
\hline $\begin{array}{l}\text { STJ REsp } \\
1.181 .820-\mathrm{MG}\end{array}$ & $\begin{array}{l}\text { j. } 2010 \\
\text { p. } 2010\end{array}$ & $3^{\mathrm{a}} \mathrm{T}$ & $\begin{array}{l}\text { Min. Nancy } \\
\text { Andrighi }\end{array}$ & $\begin{array}{l}\text { dano e ambiente/ } \\
\text { responsabilidade e civil e } \\
\text { ambiental }\end{array}$ \\
\hline $\begin{array}{l}\text { STJ REsp } \\
\text { 1.195.421-RJ } \\
\text { (Repetido no G3) }\end{array}$ & $\begin{array}{l}\text { j. } 2010 \\
\text { p. } 2010\end{array}$ & $2^{\mathrm{a}} \mathrm{T}$ & $\begin{array}{l}\text { Min. Mauro } \\
\text { Campbell }\end{array}$ & $\begin{array}{l}\text { responsabilidade e civil e } \\
\text { ambiental }\end{array}$ \\
\hline $\begin{array}{l}\text { STJ REsp } \\
\text { 1.115.555-MG }\end{array}$ & $\begin{array}{l}\text { j. } 2011 \\
\text { p. } 2011\end{array}$ & $1^{\mathrm{a}} \mathrm{T}$ & $\begin{array}{l}\text { Min. Arnaldo } \\
\text { Esteves Lima }\end{array}$ & $\begin{array}{l}\text { dano e ambiente / poluidor- } \\
\text { pagador / poluidor e } \\
\text { pagador }\end{array}$ \\
\hline $\begin{array}{l}\text { STJ REsp } \\
\text { 1.145.083-MG } \\
\text { (Repetido no G2) }\end{array}$ & $\begin{array}{l}\text { j. } 2011 \\
\text { p. } 2012\end{array}$ & $2^{\mathrm{a}} \mathrm{T}$ & $\begin{array}{l}\text { Min. Herman } \\
\text { Benjamin }\end{array}$ & $\begin{array}{l}\text { degradação e ambiente / } \\
\text { degradação e ambiental / } \\
\text { dano e ambiente/ poluidor- } \\
\text { pagador / poluidor e } \\
\text { pagador / responsabilidade } \\
\text { e civil e ambiental }\end{array}$ \\
\hline $\begin{array}{l}\text { STJ REsp } \\
\text { 1.164.587-MG }\end{array}$ & $\begin{array}{l}\text { j. } 2011 \\
\text { p. } 2012\end{array}$ & $2^{\mathrm{a}} \mathrm{T}$ & $\begin{array}{l}\text { Min. Herman } \\
\text { Benjamin }\end{array}$ & $\begin{array}{l}\text { dano e ambiente/ poluidor- } \\
\text { pagador / poluidor e } \\
\text { pagador / responsabilidade } \\
\text { e civil e ambiental }\end{array}$ \\
\hline $\begin{array}{l}\text { STJ REsp } \\
\text { 1.165.284-MG }\end{array}$ & $\begin{array}{l}\text { j. } 2011 \\
\text { p. } 2012\end{array}$ & $2^{\mathrm{a}} \mathrm{T}$ & $\begin{array}{l}\text { Min. Herman } \\
\text { Benjamin }\end{array}$ & $\begin{array}{l}\text { dano e ambiente/ poluidor- } \\
\text { pagador / poluidor e } \\
\text { pagador }\end{array}$ \\
\hline $\begin{array}{l}\text { STJ REsp } \\
\text { 1.248.214-MG }\end{array}$ & $\begin{array}{l}\text { j. } 2011 \\
\text { p. } 2012\end{array}$ & $2^{\mathrm{a}} \mathrm{T}$ & $\begin{array}{l}\text { Min. Herman } \\
\text { Benjamin }\end{array}$ & $\begin{array}{l}\text { dano e ambiente / } \\
\text { responsabilidade e civil e } \\
\text { ambiental }\end{array}$ \\
\hline $\begin{array}{l}\text { STJ REsp } \\
\text { 1.264.250-MG }\end{array}$ & $\begin{array}{l}\text { j. } 2011 \\
\text { p. } 2011\end{array}$ & $2^{\mathrm{a}} \mathrm{T}$ & $\begin{array}{l}\text { Min. Mauro } \\
\text { Campbell }\end{array}$ & $\begin{array}{l}\text { degradação e ambiental / } \\
\text { dano e ambiental }\end{array}$ \\
\hline
\end{tabular}




\begin{tabular}{|c|c|c|c|c|}
\hline $\begin{array}{l}\text { STJ REsp } \\
\text { 119.8727-MG } \\
\text { (Repetido no G2) }\end{array}$ & $\begin{array}{l}\text { j. } 2012 \\
\text { p. } 2013\end{array}$ & $2^{\mathrm{a}} \mathrm{T}$ & $\begin{array}{l}\text { Min. Herman } \\
\text { Benjamin }\end{array}$ & $\begin{array}{l}\text { poluidor-pagador / } \\
\text { internalização e ambiental } \\
\text { / usuário e pagador / } \\
\text { poluidor e pagador / } \\
\text { degradação e ambiente / } \\
\text { degradação e ambiental / } \\
\text { responsabilidade e civil e } \\
\text { ambiental / dano e ambiente }\end{array}$ \\
\hline $\begin{array}{l}\text { STJ REsp } \\
\text { 1.269.494-MG } \\
\text { (Repetido no G2) }\end{array}$ & $\begin{array}{l}\text { j. } 2013 \\
\text { p. } 2013\end{array}$ & $2^{\mathrm{a}} \mathrm{T}$ & $\begin{array}{l}\text { Min. Eliana } \\
\text { Calmon }\end{array}$ & $\begin{array}{l}\text { dano e ambiente/dano e } \\
\text { ambiental }\end{array}$ \\
\hline $\begin{array}{l}\text { STJ REsp } \\
1.307 .938-G O\end{array}$ & $\begin{array}{l}\text { j. } 2014 \\
\text { p. } 2014\end{array}$ & $1^{\mathrm{a}} \mathrm{T}$ & $\begin{array}{l}\text { Min. Benedito } \\
\text { Gonçalves }\end{array}$ & $\begin{array}{l}\text { dano e ambiente/ dano e } \\
\text { ambiental/ responsabilidade } \\
\text { e civil e ambiental }\end{array}$ \\
\hline $\begin{array}{l}\text { STJ REsp } \\
1.382 .999-\mathrm{SC}\end{array}$ & $\begin{array}{l}\text { j. } 2014 \\
\text { p. } 2014\end{array}$ & $2^{\mathrm{a}} \mathrm{T}$ & $\begin{array}{l}\text { Min. Humberto } \\
\text { Martins }\end{array}$ & $\begin{array}{l}\text { dano e ambiente/dano e } \\
\text { ambiental }\end{array}$ \\
\hline $\begin{array}{l}\text { STJ AgRg no REsp } \\
\text { 1.415.062-CE }\end{array}$ & $\begin{array}{l}\text { j. } 2014 \\
\text { p. } 2014\end{array}$ & $2^{\mathrm{a}} \mathrm{T}$ & $\begin{array}{l}\text { Min. Humberto } \\
\text { Martins }\end{array}$ & dano e ambiental \\
\hline $\begin{array}{l}\text { STJ AgRg no } \\
\text { AREsp 628.911-SC }\end{array}$ & $\begin{array}{l}\text { j. } 2015 \\
\text { p. } 2015\end{array}$ & $2^{\mathrm{a}} \mathrm{T}$ & $\begin{array}{l}\text { Min. OG } \\
\text { Fernandes }\end{array}$ & dano e ambiental \\
\hline $\begin{array}{l}\text { STJ REsp } \\
1.410 .698-\mathrm{MG}\end{array}$ & $\begin{array}{l}\text { j. } 2015 \\
\text { p. } 2015\end{array}$ & $2^{\mathrm{a}} \mathrm{T}$ & $\begin{array}{l}\text { Min. Humberto } \\
\text { Martins }\end{array}$ & $\begin{array}{l}\text { dano e ambiente/dano e } \\
\text { ambiental }\end{array}$ \\
\hline $\begin{array}{l}\text { STJ REsp } \\
1.212 .723-\mathrm{PR}\end{array}$ & $\begin{array}{l}\text { j. } 2016 \\
\text { p. } 2016\end{array}$ & $2^{\mathrm{a}} \mathrm{T}$ & $\begin{array}{l}\text { Min. Humberto } \\
\text { Martins }\end{array}$ & $\begin{array}{l}\text { dano e ambiente/dano e } \\
\text { ambiental }\end{array}$ \\
\hline $\begin{array}{l}\text { STJ REsp } \\
\text { 1.255.127-MG }\end{array}$ & $\begin{array}{l}\text { j. } 2016 \\
\text { p. } 2016\end{array}$ & $2^{\mathrm{a}} \mathrm{T}$ & $\begin{array}{l}\text { Min. Herman } \\
\text { Benjamin }\end{array}$ & $\begin{array}{l}\text { dano e ambiente/dano } \\
\text { e ambiental/poluidor- } \\
\text { pagador/ poluidor e } \\
\text { pagador/ usuário-pagador/ } \\
\text { usuário e pagador }\end{array}$ \\
\hline $\begin{array}{l}\text { STJ REsp } \\
1.355 .574-\mathrm{SE}\end{array}$ & $\begin{array}{l}\text { j. } 2016 \\
\text { p. } 2016\end{array}$ & $2^{\mathrm{a}} \mathrm{T}$ & $\begin{array}{l}\text { Min. Diva } \\
\text { Malerbi }\end{array}$ & $\begin{array}{l}\text { dano e ambiente/dano e } \\
\text { ambiental }\end{array}$ \\
\hline
\end{tabular}




\begin{tabular}{|c|c|c|c|c|}
\hline $\begin{array}{l}\text { STJ REsp } \\
\text { 1.454.281-MG }\end{array}$ & $\begin{array}{l}\text { j. } 2016 \\
\text { p. } 2016\end{array}$ & $2^{\mathrm{a}} \mathrm{T}$ & $\begin{array}{l}\text { Min. Herman } \\
\text { Benjamin }\end{array}$ & $\begin{array}{l}\text { degradação e ambiente/ } \\
\text { degradação e ambiental/ } \\
\text { dano e ambiente/dano } \\
\text { e ambiental/poluidor- } \\
\text { pagador/ poluidor e } \\
\text { pagador/ responsabilidade e } \\
\text { civil e ambiental/ usuário- } \\
\text { pagador/ usuário e pagador }\end{array}$ \\
\hline $\begin{array}{l}\text { STJ AgRg no REsp } \\
1.486 .195-\mathrm{SC}\end{array}$ & $\begin{array}{l}\text { j. } 2016 \\
\text { p. } 2016\end{array}$ & $2^{\mathrm{a}} \mathrm{T}$ & $\begin{array}{l}\text { Min. Humberto } \\
\text { Martins }\end{array}$ & $\begin{array}{l}\text { dano e ambiente/dano e } \\
\text { ambiental }\end{array}$ \\
\hline $\begin{array}{l}\text { STJ AgRg no } \\
\text { AREsp 338.744-RJ }\end{array}$ & $\begin{array}{l}\text { j. } 2016 \\
\text { p. } 2016\end{array}$ & $1^{\mathrm{a}} \mathrm{T}$ & $\begin{array}{l}\text { Min. Benedito } \\
\text { Gonçalves }\end{array}$ & $\begin{array}{l}\text { dano e ambiente/ dano e } \\
\text { ambiental/ responsabilidade } \\
\text { e civil e ambiental }\end{array}$ \\
\hline $\begin{array}{l}\text { STJ AgInt no } \\
\text { AREsp 584.736-RJ }\end{array}$ & $\begin{array}{l}\text { j. } 2016 \\
\text { p. } 2016\end{array}$ & $2^{\mathrm{a}} \mathrm{T}$ & $\begin{array}{l}\text { Min. Assusete } \\
\text { Magalhães }\end{array}$ & dano e ambiental \\
\hline $\begin{array}{l}\text { STJ AgRg no REsp } \\
\text { 1.154.986-MG }\end{array}$ & $\begin{array}{l}\text { j. } 2016 \\
\text { p. } 2016\end{array}$ & $2^{\mathrm{a}} \mathrm{T}$ & $\begin{array}{l}\text { Min. Diva } \\
\text { Malerbi }\end{array}$ & dano e ambiental \\
\hline $\begin{array}{l}\text { STJ AgRg no Ag } \\
1.365 .693-\mathrm{MG}\end{array}$ & $\begin{array}{l}\text { j. } 2016 \\
\text { p. } 2016\end{array}$ & $1^{\mathrm{a}} \mathrm{T}$ & $\begin{array}{l}\text { Min. Napoleão } \\
\text { Nunes Maia Filho }\end{array}$ & $\begin{array}{l}\text { dano e ambiente/dano e } \\
\text { ambiental }\end{array}$ \\
\hline $\begin{array}{l}\text { STJ AgInt no REsp } \\
\text { 1532643/SC } \\
\text { (Repetido no G6) }\end{array}$ & $\begin{array}{l}\text { j. } 2017 \\
\text { p. } 2017\end{array}$ & $2^{\mathrm{a}} \mathrm{T}$ & $\begin{array}{l}\text { Min. Assusete } \\
\text { Magalhães }\end{array}$ & $\begin{array}{l}\text { poluidor e pagador/ } \\
\text { poluidor-pagador/ dano e } \\
\text { ambiente/dano e ambiental/ } \\
\text { responsabilidade e civil } \\
\text { e ambiental/ degradação } \\
\text { e ambiente/ degradação e } \\
\text { ambiental }\end{array}$ \\
\hline $\begin{array}{l}\text { STJ REsp 1669185- } \\
\text { RS } \\
\text { (Repetido no G2) }\end{array}$ & $\begin{array}{l}\text { j. } 2017 \\
\text { p. } 2017\end{array}$ & $2^{\mathrm{a}} \mathrm{T}$ & $\begin{array}{l}\text { Min. Herman } \\
\text { Benjamin }\end{array}$ & $\begin{array}{l}\text { Poluidor e pagador/ } \\
\text { poluidor-pagador/ usuário e } \\
\text { pagador/ usuário-pagador/ } \\
\text { dano e ambiente/ dano e } \\
\text { ambiental }\end{array}$ \\
\hline $\begin{array}{l}\text { STJ REsp 1516278/ } \\
\text { SC }\end{array}$ & $\begin{array}{l}\text { j. } 2017 \\
\text { p. } 2017\end{array}$ & $2^{\mathrm{a}} \mathrm{T}$ & $\begin{array}{l}\text { Min. Herman } \\
\text { Benjamin }\end{array}$ & $\begin{array}{l}\text { dano e ambiente/dano e } \\
\text { ambiental }\end{array}$ \\
\hline $\begin{array}{l}\text { STJ AgInt no REsp } \\
1577376 / \mathrm{SC}\end{array}$ & $\begin{array}{l}\text { j. } 2017 \\
\text { p. } 2017\end{array}$ & $2^{\mathrm{a}} \mathrm{T}$ & $\begin{array}{l}\text { Min. } \quad \text { Og } \\
\text { Fernandes }\end{array}$ & dano e ambiente \\
\hline
\end{tabular}




\begin{tabular}{|c|c|c|c|c|}
\hline $\begin{array}{l}\text { STJ AgInt no REsp } \\
1548960-\text { SC }\end{array}$ & $\begin{array}{l}\text { j. } 2018 \\
\text { p. } 2018\end{array}$ & $2^{\mathrm{a}} \mathrm{T}$ & $\begin{array}{l}\text { Min. Mauro } \\
\mathrm{C} \text { a } \mathrm{m} \mathrm{p} \mathrm{b} \text { e } 11 \\
\text { Marques }\end{array}$ & dano e ambiental \\
\hline
\end{tabular}

\begin{tabular}{|c|c|c|c|c|}
\hline \multicolumn{5}{|c|}{$\begin{array}{l}\text { TABELA 5/ GRUPO 5: COMPENSAÇÃO AM } \\
\text { UNIDADES DE CONSERVAÇÃO (SNUC) }\end{array}$} \\
\hline Decisão (STJ/STF) & ANO & Turma & Relatoria & Palavras-chave \\
\hline $\begin{array}{l}\text { STF ADI 3.378- } \\
6-\mathrm{DF}\end{array}$ & $\begin{array}{l}\text { j. } 2008 \\
\text { p. } 2008\end{array}$ & T. Pleno & $\begin{array}{l}\text { Min. Carlos Ayres } \\
\text { Brito }\end{array}$ & $\begin{array}{l}\text { custos e ambiente / } \\
\text { custos e ambientais } \\
\text { / degradação e } \\
\text { ambiente / degradação } \\
\text { e ambiental / dano e } \\
\text { ambiente/ poluidor } \\
\text { e pagador / usuário- } \\
\text { pagador / usuário e } \\
\text { pagador / }\end{array}$ \\
\hline $\begin{array}{l}\text { STJ REsp 896.863- } \\
\text { DF }\end{array}$ & $\begin{array}{l}\text { j. } 2011 \\
\text { p. } 2011\end{array}$ & $2^{\mathrm{a}} \mathrm{T}$ & Min. Castro Meira & $\begin{array}{l}\text { dano e ambiente/ dano } \\
\text { e ambiental }\end{array}$ \\
\hline
\end{tabular}




\begin{tabular}{|c|c|c|c|c|}
\hline Decisão (STJ/STF) & ANO & Turma & Relatoria & Palavras-chave \\
\hline $\begin{array}{l}\text { STJ REsp 442.586-SP } \\
\text { (Repetido no G2) }\end{array}$ & $\begin{array}{l}\text { j. } 2002 \\
\text { p. } 2003\end{array}$ & $1^{\mathrm{a}} \mathrm{T}$. & Min. Luiz Fux & $\begin{array}{l}\text { degradação } \\
\text { e ambiente / } \\
\text { degradação e } \\
\text { ambiental / dano } \\
\text { e ambiente/ } \\
\text { responsabilidade e } \\
\text { civil e ambiental }\end{array}$ \\
\hline $\begin{array}{l}\text { STJ REsp 578.797-RS } \\
\text { (Repetido no G2) }\end{array}$ & $\begin{array}{l}\text { j. } 2004 \\
\text { p. } 2004\end{array}$ & $1^{\mathrm{a}} \mathrm{T}$. & Min. Luiz Fux & $\begin{array}{l}\text { degradação } \\
\text { e ambiente / } \\
\text { degradação e } \\
\text { ambiental/ dano } \\
\text { e ambiente/ } \\
\text { responsabilidade e } \\
\text { civil e ambiental }\end{array}$ \\
\hline $\begin{array}{l}\text { STJ REsp 1.137.314- } \\
\text { MG }\end{array}$ & $\begin{array}{l}\text { j. } 2009 \\
\text { p. } 2011\end{array}$ & $2^{\mathrm{a}} \mathrm{T}$ & $\begin{array}{l}\text { Min. Herman } \\
\text { Benjamin }\end{array}$ & $\begin{array}{l}\text { Externalidade } \\
\text { / externalidade } \\
\text { e ambiental e } \\
\text { negativa }\end{array}$ \\
\hline STJ REsp 1.251.697-PR & $\begin{array}{l}\text { j. } 2012 \\
\text { p. } 2012\end{array}$ & $2^{\mathrm{a}} \mathrm{T}$ & $\begin{array}{l}\text { Min. Mauro Campbell } \\
\text { Marques }\end{array}$ & $\begin{array}{l}\text { degradação } \\
\text { e ambiente/ } \\
\text { degradação e } \\
\text { ambiental/ dano } \\
\text { e ambiente/dano } \\
\text { e ambiental/ } \\
\text { responsabilidade e } \\
\text { civil e ambiental }\end{array}$ \\
\hline
\end{tabular}




\begin{tabular}{|c|c|c|c|c|}
\hline $\begin{array}{l}\text { STJ AgRg no AREsp } \\
62.584-R J\end{array}$ & $\begin{array}{l}\text { j. } 2015 \\
\text { p. } 2015\end{array}$ & $1^{\mathrm{a}} \mathrm{T}$ & $\begin{array}{l}\text { Min. Regina Helena } \\
\text { Costa }\end{array}$ & $\begin{array}{l}\text { degradação } \\
\text { e ambiente/ } \\
\text { degradação e } \\
\text { ambiental/ dano } \\
\text { e ambiente/dano } \\
\text { e ambiental/ } \\
\text { responsabilidade e } \\
\text { civil e ambiental }\end{array}$ \\
\hline STJ REsp 1.318.051-RJ & $\begin{array}{l}\text { j. } 2015 \\
\text { p. } 2015\end{array}$ & $1^{\mathrm{a}} \mathrm{T}$ & $\begin{array}{l}\text { Min. Benedito } \\
\text { Gonçalves }\end{array}$ & $\begin{array}{l}\text { dano e ambiente/ } \\
\text { dano e ambiental/ } \\
\text { responsabilidade e } \\
\text { civil e ambiental }\end{array}$ \\
\hline STJ REsp 1.401.500-PR & $\begin{array}{l}\text { j. } 2016 \\
\text { p. } 2016\end{array}$ & $2^{\mathrm{a}} \mathrm{T}$ & $\begin{array}{l}\text { Min. Herman } \\
\text { Benjamin }\end{array}$ & $\begin{array}{l}\text { degradação } \\
\text { e ambiente/ } \\
\text { degradação e } \\
\text { ambiental/ dano } \\
\text { e ambiente/dano } \\
\text { e ambiental/ } \\
\text { poluidor- } \\
\text { pagador/ poluidor } \\
\text { e pagador/ } \\
\text { responsabilidade e } \\
\text { civil e ambiental }\end{array}$ \\
\hline STJ REsp 1.640.243-SC & $\begin{array}{l}\text { j. } 2017 \\
\text { p. } 2017\end{array}$ & $2^{\mathrm{a}} \mathrm{T}$ & $\begin{array}{l}\text { Min. Herman } \\
\text { Benjamin }\end{array}$ & $\begin{array}{l}\text { dano e ambiente/ } \\
\text { dano e ambiental/ } \\
\text { responsabilidade e } \\
\text { civil e ambiental }\end{array}$ \\
\hline $\begin{array}{l}\text { STJ AgInt no REsp } \\
\text { 1532643/SC } \\
\text { (Repetido no G4) }\end{array}$ & $\begin{array}{l}\text { j. } 2017 \\
\text { p. } 2017\end{array}$ & $2^{\mathrm{a}} \mathrm{T}$ & $\begin{array}{l}\text { Min. Assusete } \\
\text { Magalhães }\end{array}$ & $\begin{array}{l}\text { Poluidor e } \\
\text { pagador/ poluidor- } \\
\text { pagador/ dano e } \\
\text { ambiente / dano } \\
\text { e ambiental/ } \\
\text { responsabilidade e } \\
\text { civil e ambiental/ } \\
\text { degradação } \\
\text { e ambiente/ } \\
\text { degradação e } \\
\text { ambiental }\end{array}$ \\
\hline
\end{tabular}

